Universidad Autónoma Metropolitana, Unidad Iztapalapa.

Posgrado en Humanidades, Maestría en Filosofía moral y política.

\title{
EL TRATAMIENTO FILOSÓFICO DE LA LIBERTAD EN HEGEL
}

Idónea comunicación de resultados que para optar al grado de Maestro en Humanidades, en la Línea de Filosofía Política presenta:

Luis Armando Wence Partida

Asesor: Dr. Sergio Pérez Cortés. 

Para quienes han venido ofreciéndome su cariño, su alegría, su orientación, su paciencia, su apoyo y su confianza: Almandina, Irékani, Arturo, Nancy, Anelí, Chava, María, Lupita, Chava, Marcos, Aracely, Daniel, Claudia, Alejandro, Isa, Carlos, Olga, Vicky, José Luis... 


\section{ÍNDICE}

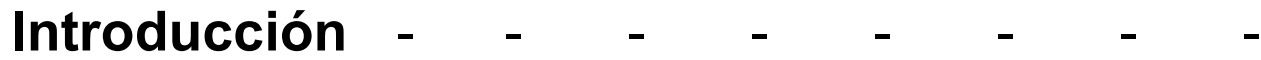

4

Capítulo 1

Las exigencias de una ciencia filosófica -

Capítulo 2

Primera crítica de la lógica unilateral - $\quad$ - $\quad$ - 23

Capítulo 3

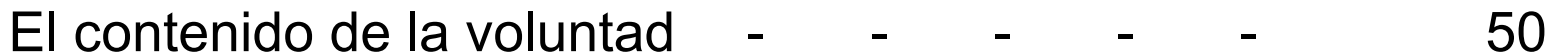

Capítulo 4

La libertad en su existencia

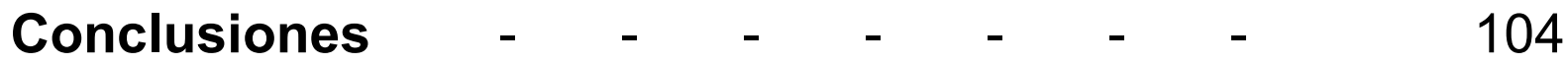

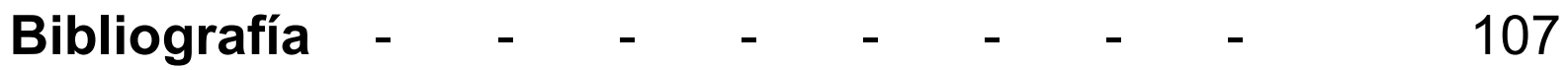




\section{INTRODUCCIÓN}

Más allá de la literatura especializada, la filosofía política de Hegel sigue siendo identificada como un planteamiento reaccionario, metafísico, estatólatra y oficialista... La Filosofía del Derecho contiene, ciertamente, algunos motivos que, tomados fuera de contexto, conducirían a pensar que el autor se contrapone abiertamente a las libertades alcanzadas en la modernidad.

La filosofía política de Hegel, sin embargo, pretende ser algo más que "otra" intervención en ese ámbito de la filosofía. La Filosofía del Derecho está planteada como una ciencia filosófica que forma parte de un sistema y que, como tal, se apega a una serie de exigencias que la distinguen de otras ciencias y de otras intervenciones en el mismo ámbito. En este sentido, cuando la obra de Hegel es desacreditada tomando como base únicamente la posible postura política que se discierne en ella, al mismo tiempo se desecha el andamiaje teórico que le subyace, y que se refiere al modo de tratar filosóficamente un objeto, en este caso la libertad.

Por el contrario, cuando la Filosofía del Derecho se estudia no sólo como el planteamiento de una postura política contingente, sino atendiendo simultáneamente a su modo peculiar (científico filosófico) de proceder, por una parte se matiza la supuesta postura política reaccionaria de su autor, por otra, se descubre que la libertad subjetiva alcanzada en la modernidad tiene perfecta cabida en su sistema, e incluso nos encontramos con un procedimiento de investigación que hoy en día tendría mucho que decirnos, en tanto que evita ser arbitrario y unilateral.

La libertad es una idea cardinal para la filosofía política moderna. En ella descansa la fundamentación del derecho y del Estado. Pero, de un autor a otro, de una tradición filosófica a otra, no sólo varía su comprensión, sino que incluso se la llega a pensar en términos francamente antagónicos, excluyentes; todo depende del aspecto que se decida priorizar en cada caso. Es ante dicho panorama que resulta necesario recurrir al planteamiento hegeliano. Entre otras posibilidades, el tratamiento filosófico de la libertad que Hegel 
propone, permite superar una serie de oposiciones excluyentes en las que suelen enfrascarse las discusiones de la filosofía política moderna y contemporánea.

El interés por emprender un tratamiento científico-filosófico de la libertad es un proyecto que se puede rastrear desde los primero textos de Hegel. Así, por ejemplo, en Sobre las maneras de tratar científicamente el derecho natural..., que vio la luz en 1802, el filósofo confronta los planteamientos del empirismo y del formalismo. En términos generales, lo que critica del tratamiento empírico del derecho es que, tomando como fundamento la intuición sensible, pretenda hacer pasar por esencial alguna determinación que realmente sería parcial; le reprocha que, de manera arbitraria, quiera elevar a la universalidad alguna experiencia más bien contingente. En tanto que al tratamiento formal del derecho le critica que se aferre a la abstracción absoluta, vacía de todo contenido, de donde luego se desprende una relación de externalidad infranqueable entre el mundo de la libertad y el de la necesidad.

Pero lo relevante del procedimiento hegeliano es que, toda vez que adopta una perspectiva que en ese momento ya denomina de "la ciencia" y/o "el concepto", al mismo tiempo recoge el momento conceptual irrenunciable que representa cada una de las posturas confrontadas. En la introducción a la Filosofía del derecho Hegel sugiere que cada una de aquellas posturas corresponde a un momento necesario para alcanzar, (luego de la contradicción en que incurren ellas mismas), una concepción más plena de la libertad, en la que ambos momentos estarían involucrados, aunque negados en su unilateralidad. Tenemos entonces que, además de destacar la importancia de la libertad individual, Hegel reconoce al empirismo la virtud de ceñirnos a la experiencia, lo que en la modernidad ha evitado el riesgo de querer asentar el derecho en algún principio sobrenatural o trascendente. Del formalismo retoma, por su parte, el principio de la autonomía subjetiva y la necesidad de universalizar, ya que ambos son aspectos indispensables para la fundamentación racional del derecho.

Ahora bien, el presente trabajo no se queda con aquella obra temprana porque, como se sabe, a partir de la Fenomenología del espíritu, publicada en 1807, se produjo una notable transformación en el planteamiento filosófico de Hegel, gracias a lo cual éste pudo distanciarse del idealismo trascendental y del romanticismo. Es a partir de entonces que se perfila el pensamiento sistemático de Hegel, donde lo relevante ya no es interponer la perspectiva de la "totalidad ética" como una tercera opción en la disputa entre el empirismo y 
el formalismo, sino seguir el despliegue inmanente de la propia voluntad, desde su forma más inmediata (el derecho abstracto), hasta su concreción en las instituciones de la eticidad.

El principal texto que hemos revisado para este trabajo, por lo tanto, es la Filosofía del derecho, de 1821, dado que allí expone Hegel el modo en que la libertad se despliega en su concepto y en su existencia. Hegel sostiene en esta obra de madurez que la eticidad constituye un ámbito en el que se subsumen y adquieren sentido el derecho abstracto y la moralidad; nos dice también que la eticidad es la identidad concreta del bien con la voluntad subjetiva... Pero tales afirmaciones pueden ser desconcertantes, hoy en día, a menos que se considere el trasfondo lógico que les da sentido. Bajo esta perspectiva, lo que hemos intentado destacar es el entramado lógico que le da sentido al contenido manifiesto de la filosofía política de Hegel, y que le permite llegar a determinadas conclusiones.

Este componente lógico es lo que le da un carácter propio y peculiar a la obra de Hegel y, al revisarlo, resulta posible despejar también la supuesta postura reaccionaria que se le adjudica.

El trabajo está organizado del siguiente modo: en un primer apartado se abordan las exigencias que toda ciencia filosófica debiera atender, de acuerdo con Hegel, delineadas principalmente en la parte introductoria de la Ciencia de la Lógica. En el segundo apartado, y dada la importancia de Kant sobre la obra de Hegel, primero se presenta brevemente el modo en que Kant fundamenta la libertad, y luego se revisa la temprana reacción que despertó en Hegel, consignada en el ensayo titulado Sobre las formas de tratar científicamente el derecho natural... En el tercer y cuarto apartado se expone propiamente el modo en que Hegel propone que se desplieguen el contenido de la voluntad y las configuraciones de la libertad en su existencia. Por último, se cierra con algunas conclusiones. 


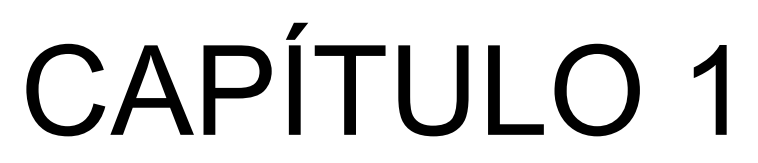

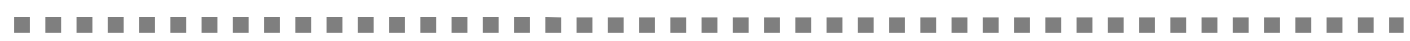

\section{LAS EXIGENCIAS DE UNA CIENCIA FILOSÓFICA}


Alguien observará que la conclusión precedió sin duda a las "pruebas". ¿Quién se resigna a buscar pruebas de algo no creído por él o cuya prédica no le importa?

Borges, Artificios.

La lectura de la Filosofía del Derecho de Hegel que hemos querido emprender en este trabajo ha sido motivada directamente por una de las indicaciones que el propio autor adelanta en el Prefacio a dicha obra.

Por principio de cuentas, como se sabe, la Filosofía del Derecho desarrolla solamente una parte del sistema. Se trata de aquella parte en la que Hegel se ocupa del "espíritu objetivo", esto es, donde quiere dar cuenta de la libertad "en su concepto y en su realización”. (FD., §1) Como parte del sistema, entonces, la Filosofía del Derecho tiene un objeto concreto. Es dable pensar entonces que, cuando alguien quiere conocer la postura política de Hegel, o cuando quiere conocer la perspectiva del autor en torno al derecho, no tendría más que hacer sino acercarse precisamente a esa obra.

Diversos lectores y comentaristas de Hegel se han aproximado así a la Filosofía del Derecho, con el ánimo de entresacar de ella la postura política del autor. $Y$ es de este modo como luego se ha llegado a conclusiones que hoy en día nos resultan ya conocidas: que la filosofía política de Hegel representa una crítica de las teorías del contrato social (Cfr. Smith, 2002:14); que la libertad sólo se realiza efectivamente en el Estado (Cfr. Pippin, 1981:511); que la clave de la Filosofía del Derecho es haber tematizado una forma de 'libertad social' (Cfr. Neuhouser, 2000:5); que la filosofía política de Hegel resuelve el dilema entre individuo y sociedad (Cfr. Steinberger, 1988:40); que el concepto de reconocimiento es crucial para el proyecto hegeliano de mediación entre la libertad subjetiva moderna y la sustancia ética clásica (Cfr. Williams, 1997:114), entre otras...

$Y$ todas estas afirmaciones son, sin duda, apropiadas. Muchos nos hemos involucrado en el intento de describir el pensamiento político de Hegel y, cuando creemos haberlo conseguido, nos parece que estamos en condiciones de evaluar también a qué corriente pertenece, cuáles han sido sus antecedentes y qué motivos ha tenido para distanciarse de otras posturas políticas. Cuando se procede así, suele tomarse un rasgo distintivo del pensamiento político del autor, uno al cual se encuentra lo suficientemente 
abarcador, como para evaluar desde allí no sólo la Filosofía del Derecho, sino también su relación con otras tradiciones políticas.

No se trata de sugerir ahora que este tipo de tratamiento carece de relevancia. De ningún modo. La reconstrucción del pensamiento político de Hegel y su clara exposición, (como la de todo clásico) es una labor necesaria.

Para el presente trabajo, sin embargo, hubo una indicación en el Prefacio a la Filosofía del Derecho que alentó una perspectiva distinta, y esto es lo que ha venido animando su lectura. Como podrá notarse, tampoco es que se proponga una visión del todo novedosa, pues ya otros comentaristas han puesto en ello el foco de su atención, pero sí se aborda un aspecto en el cual conviene insistir, nos parece, por tratarse de un elemento irrenunciable y muy peculiar del sistema filosófico hegeliano. El pasaje del Prefacio al que hacemos referencia es el siguiente, que cito en extenso:

He desarrollado detalladamente en mi Ciencia de la lógica la naturaleza del saber especulativo, por lo que en este compendio [la Filosofía del Derecho] sólo se agregará ocasionalmente alguna aclaración sobre el procedimiento y el método. Ante el carácter concreto y en sí tan diverso del objeto, se ha dejado de lado el poner de relieve y demostrar en cada caso la concatenación lógica. Esto hubiera podido resultar superfluo dado que se supone el conocimiento del método científico, y por otra parte resultará evidente que tanto el todo como el desarrollo de las partes descansan sobre el espíritu lógico. Quisiera que se entendiese y juzgase este tratado teniendo en cuenta especialmente este aspecto, pues de lo que se trata aquí es de la ciencia, y en ella la forma está esencialmente ligada al contenido. (FD., Prefacio, p. $41)^{1}$

Hegel ya se ocupó entonces, en la Ciencia de la lógica, de la naturaleza del saber especulativo y, al hacerlo, habría expuesto lo que considera el procedimiento más adecuado para desarrollar una ciencia filosófica.

La Filosofía del Derecho, por su parte, no se ocupa del saber especulativo, pero no deja de ser una ciencia filosófica; en consecuencia, debe atenerse también a lo expuesto previamente en la Ciencia de la lógica. Esto supone que, cuando la Idea del Derecho se aborda filosóficamente, el método científico-filosófico es algo que simplemente ya debe ser conocido. La Filosofía del Derecho se ciñe entonces al mismo "espíritu lógico" que rige todo el sistema, y Hegel nos pide explícitamente que atendamos este aspecto. Más aún, entender

\footnotetext{
${ }^{1}$ Se utiliza la traducción al español de Juan Luis Vermal, publicada por EDHASA, Barcelona, 1988.
} 
que la ciencia filosófica del derecho se rige por el mismo espíritu lógico de todo el sistema, nos advierte el autor, no es algo secundario, sino que de ello depende exactamente que se distinga a la Filosofía del Derecho de otros tratados o compendios, de ello depende también que se distinga al procedimiento filosófico de otro tipo de conocimientos, y de ello depende, en fin, que la filosofía salga de la decadencia en la que ha caído. (Cfr. FD, Prefacio; p. 40)

Leer la Filosofía del Derecho a la luz de la Ciencia de la lógica es, entonces, un asunto de primera importancia. Por eso es indispensable que volvamos la mirada sobre aquella obra, y esto es lo que haremos en el presente apartado. Trataremos de discernir cuáles son las exigencias que, de acuerdo con Hegel, toda ciencia filosófica debiera atender. Una vez hecho lo anterior, revisaremos el modo en que aquellas exigencias operan en la ciencia filosófica del derecho.

\section{LAS EXIGENCIAS DE UNA CIENCIA FILOSÓFICA.}

Para cumplir nuestro propósito, nos detendremos en la sección introductoria a la Ciencia de la Lógica, también conocida como la Lógica mayor, que es donde Hegel expone propiamente las exigencias que toda ciencia filosófica, incluida la Filosofía del Derecho, debiera tener en cuenta.

Recientemente, algunos intérpretes de Hegel han destacado que, lejos de ser un texto que carezca de sentido, (como la lógica formal pretende), la Ciencia de la lógica constituye uno de los planteamientos de auto-crítica más radicales en la modernidad, en la línea comenzada por Descartes y ampliada por Kant. Veamos en qué sentido se afirma lo anterior. $^{2}$

\section{a. Suspender las reflexiones preliminares.}

\footnotetext{
${ }^{2}$ Para el desarrollo de esta sección me he valido sobremanera del trabajo introductorio de Stephen Houlgate (2006) a la Ciencia de la Lógica.
} 
Lo propio de la ciencia filosófica, nos dice Hegel, es comenzar por el objeto mismo. Esto quiere decir que, previo a la investigación, el filósofo está obligado a dejar de lado cualquier tipo de reflexión, cualquier principio o definición que ya tenga por anticipado en relación al objeto que está por estudiar. Porque, si antes de ingresar a la investigación filosófica ya se cuenta con algún principio establecido al que sólo se intenta afianzar, ese principio, esa reflexión preliminar o ese "prejuicio" no sería sino un planteamiento arbitrario. Ha de ser en el curso de la investigación filosófica, nos dice Hegel, donde se defina el contenido de las determinaciones que estamos por desarrollar, no antes de ingresar en ella.

Una ciencia filosófica, especialmente la lógica, no debiera dar por hecho, piensa Hegel, ni siquiera las reglas o las leyes del pensamiento que la lógica tradicional ha venido estableciendo como un andamiaje seguro, tales como el principio de no-contradicción. Incluso estas leyes del pensamiento debieran fundamentarse en la investigación filosófica. Y si las leyes o reglas del pensamiento no debieran aceptarse de antemano, mucho menos otra clase de principios o contenidos particulares relativos a un objeto.

...el comienzo tiene que ser absoluto, o lo que aquí significa lo mismo, un comienzo abstracto; no debe presuponer nada, no debe ser mediado por nada, ni tener un fundamento; más bien debe ser él mismo el fundamento de toda la ciencia... (LOG., pp. $90-91)^{3}$

Una de aquellas reflexiones preliminares que tendrían que dejarse en suspenso, y en la que Hegel pone un énfasis particular, es la que afirma que los pensamientos están por un lado, nosotros, en cuanto conciencias finitas, por otro, y las cosas por otro, como si fuesen tres términos que permanecerían separados y que serían autosuficientes el uno con respecto al otro. Semejante planteamiento coloca de un lado la forma y del otro al contenido, de un lado la certeza y del otro la verdad. Según este presupuesto, la verdad sólo tiene sitio, eventualmente, cuando se logra que el pensamiento y la realidad "concuerden". Pero la ciencia filosófica exige dejar atrás, es decir, "en el umbral de la filosofía", esta y otras reflexiones preliminares:

La oposición entre una inmediatez autosuficiente del contenido y del saber, y una inmediatez igualmente autosuficiente que no sea asociable con la [otra] inmediatez, hay que apartarla, en primer término, porque es una mera presuposición y una aseveración arbitraria. (Enc., §78)

\footnotetext{
${ }^{3}$ Se utiliza la traducción al español de Rodolfo y Augusta Mondolfo, publicada por Solar-Hachete, Buenos Aires, 1968.

${ }^{4}$ Se utiliza la traducción de Valls-Plana, publicada por Alianza Editorial, 1997.
} 
En relación a esta primera exigencia para la ciencia filosófica, cabe notar que Immanuel Kant había dado un paso enorme en el esfuerzo por socavar la presupuesta separación que el pensamiento y el objeto guardan entre sí para dar con la verdad. Lo anterior, cuando demuestra que las categorías son un producto de la razón, quien las genera con autonomía de la intuición sensible. Pero, a fin de cuentas, el idealismo trascendental se queda corto, a juicio de Hegel, cuando le asigna un sentido puramente subjetivo a las categorías, cuando las fija como meras formas lógicas que carecen de contenido. En ese tenor, el idealismo trascendental terminó por compartir el mismo prejuicio de la conciencia ordinaria: la convicción de que existe una separación infranqueable entre el pensamiento y su objeto, así como entre el fenómeno y lo en sí.

\section{b. Comenzar por lo más indeterminado.}

Para el punto de vista del idealismo trascendental debe parecer injustificada la exigencia de renunciar o, mejor dicho, de tener que someter a la crítica también el presupuesto de que la forma y el contenido serían cosas aisladas. ¿Cómo podrían la forma y el contenido estar "ligados esencialmente”? ¿Cómo podría el pensamiento hacerse de contenido si no es por medio de la intuición?

Lo que se exige a la ciencia filosófica, sin embargo, no es que ahora se comience por la unidad, como si tratase de un nuevo principio que ahora tendríamos que aceptar como algo preestablecido. No. En este caso, la Fenomenología del espíritu ha cumplido una labor propedéutica con respecto a la Ciencia de la lógica. Como se sabe, Hegel expuso en aquella obra la experiencia de la conciencia que, comenzando por la certeza inmediata, se percata gradualmente de que las cosas, que suponía situadas frente a sí, "no son en sí mismos sino objetos del pensamiento." (LOG., p. 47). Como resultado, cuando la conciencia ordinaria va sometiendo sus convicciones a la auto-crítica, cuando se retrotrae a la inmediatez, poco a poco se percata de que comparte una misma estructura lógica con el ser. $\mathrm{Y}$, de acuerdo con Hegel, en esto consiste precisamente "la ciencia", cuyo contenido viene a ser

...el pensamiento, en cuanto éste es también la cosa en sí misma, o bien (...) la cosa en sí, en cuanto ésta es también el pensamiento puro. Como ciencia, la verdad es la pura conciencia de sí mismo que se desarrolla... (LOG., p. 65) 
Tal como escribe Karen NG, llegados al momento de la ciencia, que es el punto de llegada de la Fenomenología, “...la forma del pensamiento es inseparable de lo que se piensa." (NG, 2010: 149)

Por difícil que parezca, entonces, cuando el pensamiento renuncia a las reflexiones preliminares, especialmente a la oposición que caracteriza a la conciencia, sí tiene un contenido. Ese contenido es el pensamiento del pensamiento que, en la Lógica, es equivalente al pensamiento inmediato del puro ser, ya que "La inteligencia sabe que lo que es pensado, es; y que lo que es, solamente es en tanto es pensamiento para sí..." (Enc., §465) He aquí el punto de llegada de la Fenomenología, y el punto de partida de la Lógica. A partir de este momento, la tarea de la Lógica consiste en desplegar lo que contenga el pensamiento indeterminado del puro ser.

Una segunda exigencia para toda ciencia filosófica consiste pues en comenzar por lo más indeterminado, por lo más inmediato y abstracto. En el caso de la Lógica, por ser la ciencia que se ocupa del saber especulativo, ese comienzo es el puro ser. En el caso de las otras ciencias, que ya de por sí tienen un objeto concreto, su comienzo no es lo más indeterminado en este sentido absoluto, sino lo más inmediato de su propio objeto.

Es preciso subrayar, entre tanto, que la identidad entre el pensamiento en su inmediatez y el puro ser, no responde a la adopción ingenua de la convicción que había sido válida en la metafísica tradicional. Aquí se trata del punto de llegada de la conciencia que ha hecho la experiencia de someter a la auto-crítica su certeza inicial. Hegel no pasa pues por alto los límites que el idealismo trascendental le había impuesto a la metafísica tradicional; por el contrario, cuando propone que el comienzo de la ciencia sea el pensamiento más inmediato del ser, no parece hacer otra cosa que llevar al extremo las exigencias de autocrítica del idealismo trascendental: al idealismo trascendental le hacía falta someter a la crítica el presupuesto básico de la conciencia, la convicción de que su objeto es algo extraño.

Y cabe hacer también otro par de aclaraciones. Como Stephen Houlgate señala: 1) Hegel no está sugiriendo que sí podamos "acceder" automáticamente a un ser situado fuera de nosotros; más bien propone que dejemos de asumir que el ser es "algo más", aparte de aquello que el pensamiento es mínimamente consciente en su inmediatez. 2) Hegel tampoco 
propone que el ser sólo exista para el pensamiento, ni que el pensamiento sea la causa del ser empírico de todo lo que existe, (o de la mera forma en que se nos presenta el ser empírico). Lo que Hegel argumenta es que “...el ser es, en sí mismo, una forma lógica inteligible y que el pensamiento es la consciencia directa de dicho ser inteligible." (Cfr. Houlgate, 2006:117 y 130) Este es, en efecto, el sentido que Hegel quiere darle al comienzo de la ciencia filosófica, donde...

...se conoce el ser como puro concepto en sí mismo, y el puro concepto como el verdadero ser. (LOG., 78-79)

\section{c. Avanzar con el auto-movimiento de las categorías.}

Hegel propone por último que, además de suspender toda reflexión preliminar y además de comenzar por lo más inmediato, la ciencia filosófica avance únicamente al explorar las determinaciones o el contenido que las categorías demuestran tener en su interior. De acuerdo con esta exigencia, el desenvolvimiento de las categorías ha de ser el fruto de un movimiento necesario, cuyo motor es interno: la negación contenida en las propias categorías. Las determinaciones que surjan del pensamiento de lo indeterminado han de provenir, entonces, del interior:

La forma así presentada en el pensamiento en toda su pureza contiene en sí misma su capacidad de determinarse, es decir, de darse a sí misma un contenido y de dárselo en su necesidad, como sistema de las determinaciones del pensamiento. (LOG., p. 82-83)

Esta exigencia de la Ciencia de la lógica nos estaría indicando que ni la dialéctica ni ningún otro modelo fijo de procedimiento deberían tomarse como una especie de "método hegeliano" preestablecido, como para "aplicarse" mecánicamente a cualquier objeto. En todo caso, el ser dialéctico, el negarse internamente o el ser contradictorio es un rasgo del objeto mismo y de las propias categorías, pero no un instrumento aplicado por el filósofo. La negación no es algo que les venga de fuera a las categorías, sino algo que surge en su interior. Es así como lo expresan todas las categorías tratadas en el sistema hegeliano, comenzando por la del "puro ser", que se expone, al mismo tiempo, como la "pura nada". Según lo advierte Hegel en la Nota al \$214 de la Enciclopedia, la lógica nos enseña precisamente que la verdad de las categorías radica en su contradicción interna: en que son 
y, al mismo tiempo, no-son lo que parecen ser, contraviniendo uno de los principios elementales de la lógica tradicional.

Aquello por cuyo medio el concepto se impele adelante por sí mismo es lo negativo (...) que contiene en sí; éste es el verdadero elemento dialéctico. (LOG., p. 73)

De lo dicho se desprende también que la tarea de una ciencia filosófica consiste en ocuparse de cada categoría y en explorar lo que cada una de ellas contiene. Por esto mismo es inapropiado que en el curso de la investigación filosófica se cuente ya con algún criterio, algún punto de vista estándar o alguna conclusión preestablecida desde la cual se irían juzgando las limitaciones o las carencias de las categorías todavía indeterminadas. Las determinaciones a las que se llegue como fruto del auto-movimiento de las categorías no deben ser posiciones extrañas a la categoría inicial, sino el resultado de su propio desenvolvimiento. La ciencia filosófica no debiera pues avanzar sustituyendo unas determinaciones por otras, cual si se tratase de posturas equivocadas para un punto de vista conocido de antemano. La ciencia filosófica ha de proceder, piensa Hegel, mostrando el modo en que las categorías salen de su abstracción y adquieren un carácter cada vez más concreto.

En efecto, mediante este avance el comienzo [sólo] pierde lo que tiene de unilateral, es decir, la cualidad de ser en general un inmediato y un abstracto... (Ibíd., p. 93)

A fin de cuentas, el hecho de que el pensamiento y su objeto, (que comparten la misma estructura lógica), estén marcados por la auto-negación y la contradicción interna, significa que no existe ningún principio particular que condicione previa y externamente su desenvolvimiento. De allí la exigencia de que la ciencia filosófica, si ha de ser auto-crítica, no recurra a "otros principios", más adecuados, que vendrían a disputar con los ya existentes. En una palabra, la razón es autosuficiente y está movida por la negatividad. (Véase Marrades, 2001: 223-5)

Con esto hemos bosquejado al menos tres de las exigencias básicas a las que una ciencia filosófica auto-crítica se debiera ajustar, de acuerdo con Hegel: la exigencia de 
suspender toda reflexión preliminar, la de comenzar por lo inmediato y la de avanzar exclusivamente en función del auto-movimiento de las categorías. Volvamos ahora a la ciencia filosófica del derecho, con el fin de valorar el modo en que estas exigencias operan cuando la filosofía se ocupa de un objeto concreto, la libertad.

\section{LA FILOSOFÍA DEL DERECHO Y LA CIENCIA DE LA LÓGICA.}

Es claro que el objeto de la Ciencia de la lógica y el de la Filosofía del derecho son muy diversos. Aun así, en el pasaje del Prefacio que citamos al comienzo, Hegel no sólo nos advierte que la Filosofía del derecho requiere de la Lógica, sino que pide abiertamente que se la juzgue tomando en cuenta esa relación.

En un comentario al respecto, Adriaan Peperzak reprocha que, si la Ciencia de la lógica era tan importante para comprender la Filosofía del derecho, Hegel debía ser más explícito en el modo en que se relacionan. Al comentarista le parece extraño que el filósofo haya despachado el asunto tan de prisa, sin detallar el modo en que un texto sustenta o concreta al otro. (Peperzak, 1987:49) Por lo que puede interpretarse, sin embargo, la indicación de Hegel es clara en cuanto a que, de lo que se trata, es de juzgar a la Filosofía del derecho como una "ciencia filosófica" en la que la concatenación lógica de los conceptos se rige por el mismo espíritu lógico de todo el sistema. Esto supone que la obra no podría comprenderse exclusivamente por su contenido manifiesto. Valls-Plana abona en este sentido cuando comenta que

...la filosofía de Hegel no puede ser comprendida ni rectamente valorada a partir de sus contenidos materiales, los cuales comparte él frecuentemente con otros autores de su tiempo, menos conocidos por nosotros. Comprensión y correcta valoración de Hegel pasan, por tanto, por el buen entendimiento de su modo peculiar de conceptualizar y por no despojar su escritura de la codificación conceptual. ${ }^{5}$

¿Qué se aprecia, entonces, cuando se lee la ciencia filosófica del derecho a la luz de la Ciencia de la lógica?

\footnotetext{
${ }^{5}$ En la nota número 3 de la traducción de la Enciclopedia de las ciencias filosóficas al español; Editorial Alianza; p. 60.
} 
1. Primero, que en el terreno del "espíritu objetivo" también es necesario comenzar, en cierto modo, con la suspensión de toda reflexión preliminar. Aquí también suele contarse por anticipado con algún principio en torno a la libertad, el derecho o el estado, al cual sólo se busca afianzar en el transcurso de la investigación; suele pensarse también que de un lado está el filósofo, de otro lado está el mundo espiritual y de otro las ideas sobre el mundo espiritual; y suele pensarse, en fin, que las ideas están separadas de la realidad y no logran afectarla.

Este prejuicio, sin embargo, es el primero que una ciencia filosófica auto-crítica debiera suspender. Es por eso que Hegel confronta reiteradamente la representación según la cual, tratándose del mundo espiritual, la tarea del filósofo consistiría en "inventar" una teoría novedosa y particular, como si el mundo espiritual estuviese siguiendo, hasta antes de la irrupción del filósofo, un derrotero azaroso desligado de la razón.

Atendiendo a la primera de las exigencias de la Lógica, es arbitrario comenzar la investigación con un principio establecido como este; es arbitrario suponer que la razón está de nuestro lado, ajena del mundo espiritual que ya es, y que la verdad sólo tendrá lugar, eventualmente, si logramos hacer que coincidan.

Puesto que se trata de una ciencia, Hegel exige que la Filosofía del derecho también comience por el objeto mismo, (aquí la Idea del derecho), y que se ocupe de "concebir lo que es, porque lo que es, es la razón.” (FD., Prefacio, p. 52) Tratándose del espíritu objetivo, la ciencia filosófica también comienza cuando se reconoce que la ldea es la razón interna que hace ser a la realidad, supuestamente externa, lo que ella es. En otras palabras, aquí también es necesario suspender la convicción de que la realidad empírica gozaría de verdad por sí misma. (Cfr. Pawlik, 2005: 23-4)

Con esto, la Ciencia de la lógica despeja uno de los asuntos más polémicos en las lecturas convencionales de la filosofía política de Hegel. Cuando Hegel afirma que su tratado es “...el intento de concebir y exponer el estado como algo en sí mismo racional” (FD., Prefacio, p. 52), no es que busque legitimar al orden político vigente, simplemente afirma que la verdad de lo real está en la razón, y que el propósito de la filosofía es de carácter conceptual:

De lo que se trata, entonces, es de reconocer en la apariencia de lo temporal y pasajero la sustancia, que es inmanente, y lo eterno, que es presente (...) Estas 
relaciones infinitamente variadas que se construyen en la exterioridad gracias al aparecer en ella de la esencia, este infinito material y su regulación, no son, sin embargo, objeto de la filosofía. (FD., Prefacio, 51)

En este sentido, el comienzo de la ciencia filosófica del derecho también debe ser abstracto, pero abstracto en la medida que se aparta de aquella convicción más bien propia de la conciencia ordinaria, según la cual, de un lado están las ideas y de otro el mundo espiritual. (Cfr. McGilvary, 1987: 500-503)

Suspender las reflexiones preliminares en el ámbito del espíritu objetivo significa pues dejar en suspenso cualquier idea del estado, cualquier principio en torno al derecho que ya tengamos, para examinarla en el curso de la propia investigación. Es decir, en una ciencia filosófica del derecho no se trata de venir a confrontar las ideas precedentes en torno al estado, para defender una nueva; se trata, en todo caso, de explorar el modo en que la voluntad se realiza a partir de su pura inmediatez. Y significa, como hemos dicho, dejar de dar por sentado que la razón y el mundo espiritual son ámbitos que corren paralelos, ajenos el uno del otro, esperando a que alguien los haga concordar.

2. La Ciencia de la lógica nos permite dimensionar, en segundo término, la importancia de comenzar por lo más inmediato e indeterminado en la Filosofía del derecho. Tanto si se trata de estudiar el contenido de la voluntad, como si se trata de las configuraciones de la libertad en su existencia, lo que se exige es que, una vez que hayamos suspendido las reflexiones preliminares, comencemos por lo más indeterminado y abstracto.

Anteriormente, advierte Hegel, la libertad solía demostrarse echando mano de distintas "sensaciones y fenómenos de la conciencia común, tales como el arrepentimiento, la culpa y otros similares que sólo pueden explicarse si la voluntad es libre..." Y hubo quienes afirmaban que "...la libertad está dada como un hecho de la conciencia y (...) que se debe creer en ella." (FD., §4, Observación) Pero este modo de proceder es inapropiado para una ciencia filosófica que se atiene a las exigencias de la Lógica. 
Como veremos en los capítulos tres y cuatro del presente trabajo, hay dos momentos clave de la Filosofía del derecho en los que Hegel se ciñe a esta exigencia de comenzar por lo más indeterminado: cuando se pregunta por el contenido de la voluntad y cuando estudia las configuraciones de la voluntad en la existencia, es decir, el derecho. En ambos casos, Hegel comienza por lo más inmediato del objeto, explorando desde allí lo que éste demuestra que contiene en su interior. Al estudiar el contenido de la voluntad en la Filosofía del derecho, por ejemplo, Hegel no empieza dando por hecho que la voluntad está condicionada por los instintos; tampoco asume que se trata de una capacidad con la cual nos dota la naturaleza, y evita suponer igualmente que podríamos deducirla de la conciencia del deber...; simplemente toma a la voluntad en su inmediatez. Porque, como advierte Terry Pinkard, lo que se exige es comenzar por aquello que demuestra que ya no tiene ningún otro antecesor más primitivo. (Cfr. Pinkard, 1979: 422-423) Y esto es precisamente lo que hace Hegel. Nuestro autor podría comenzar con el resultado, pero, siendo congruente con los planteamientos de la Lógica, más bien comienza con la reflexión del yo en sí mismo, con la pura indeterminación, para explorar desde allí las determinaciones a las que esto da lugar.

Así mismo, cuando se estudia el derecho o las configuraciones de la libertad, Hegel evita comenzar con la búsqueda de algún fundamento en nociones previas, que implicarían algún tipo de concreción: el poder, el individuo, la génesis histórica, la costumbre u otras. Este tipo de procedimiento, advierte el autor, colocaría "la apariencia en el lugar de la naturaleza de la cosa". (FD., §3, Observación) Desde un tratamiento filosófico, el estudio del derecho ha de comenzar por la voluntad que carece de mediación, por lo más abstracto, y discernir desde allí el modo en que ésta se determina.

3. Y el otro aspecto en donde se percibe una clara presencia de las exigencias de la Ciencia de la lógica en la Filosofía del derecho es el relativo al auto-movimiento de las categorías. Hegel nunca procede poniendo como criterio la conclusión. Es decir, Hegel no piensa por anticipado en el resultado de la Filosofía del derecho para juzgar desde allí las configuraciones del derecho abstracto y la moralidad. Puesto que se trata de una ciencia filosófica, lo que hace nuestro autor es demostrar precisamente que el contenido de la voluntad y sus diversas configuraciones provienen del interior del objeto mismo, en la medida que cada momento positivo se contradice a sí mismo. 
$\mathrm{Y}$ esto es lo que produce el movimiento $\mathrm{y}$ el despliegue hacia nuevas determinaciones.

El desarrollo inmanente de una ciencia, la deducción de la totalidad de su contenido a partir del concepto simple (de no ser así no merece por lo menos el nombre de ciencia filosófica), muestra la peculiaridad de que uno y el mismo concepto, en este caso la voluntad, que en un comienzo -precisamente por ser el comienzo- es abstracto, se conserva y al mismo tiempo produce por sí mismo sus determinaciones y gana de este modo un contenido concreto. (FD., §279, Observación)

Las determinaciones a las que da lugar una categoría que se despliega no son, por tanto, un añadido del filósofo, sino que “...este segundo momento está ya incluido en el primero y es sólo un poner lo que el primero ya es en sí." (FD., §6, Observación)

Hegel no enjuicia pues los planteamientos del derecho abstracto y la moralidad desde el punto de vista de la eticidad, sino que avanza justamente por donde la propia categoría, inicialmente indeterminada, le conduce. En su tratamiento filosófico de la voluntad libre no se sabe de antemano que la pura indeterminación dará como resultado la autodeterminación concreta; esto es algo que se concluye del auto-movimiento de la categoría. Tampoco se sabe de antemano que las configuraciones de la libertad en su existencia, que comienzan con el derecho abstracto, van a llegar a la eticidad. El momento de la autodeterminación concreta y la eticidad son, en todo caso, un resultado al que se llega de modo necesario.

Esto también significa que la crítica de Hegel a otros planteamientos en el ámbito de la filosofía práctica, como pueden ser los del contractualismo y los de Kant, no se hace teniendo como referencia un resultado ya previsto por Hegel, sino que dichos contenidos entrarían por sí mismos en contradicción, exigiendo avanzar hacia otras configuraciones, cada vez más complejas.

...en la ciencia, el concepto se desarrolla desde sí mismo y progresa y produce sus determinaciones de un modo inmanente. (FD., §31)

Cuando se revisa la Filosofía del derecho bajo esta perspectiva, entonces, es claro el modo en que se atienden las exigencias de la Ciencia de la lógica, haciendo con ello más comprensibles los momentos, el desarrollo y las conclusiones de la obra. $\mathrm{Y}$ es por eso que, 
si estamos interesados en conocer el planteamiento político del autor, no es suficiente con detenerse en aquellos tópicos que lo caracterizan externamente, como pueden ser los contenidos de la eticidad. Esto permite apreciar, adicionalmente, que las conclusiones a las que llega el autor no consisten en posturas arbitrarias, sino un planteamiento inscrito en las exigencias de auto-crítica de la modernidad, un planteamiento justificado por el despliegue inmanente del concepto mismo de libertad.

Resulta claro también que no podría prescindirse tan fácilmente de las exigencias de la Ciencia de la lógica en la Filosofía del derecho. En su estudio sobre la Filosofía del derecho, Frederick Neuhouser (2000) expone el modo en que Hegel fundamenta la racionalidad de un orden social. Allí, el comentarista destaca que el planteamiento hegeliano tiene un enorme potencial crítico y unos estándares muy elevados para determinar qué instituciones cumplirían realmente con las exigencias de libertad de la razón moderna. Bajo esta perspectiva, analiza a detalle los componentes subjetivo y objetivo de la libertad en la propuesta de Hegel y el modo en que ambos coinciden en la eticidad.

Al igual que algunos otros lectores y comentaristas, sin embargo, Neuhouser piensa que las afirmaciones de Hegel en torno al "espíritu lógico" que anima la Filosofía del derecho son un ingrediente del que, preferiblemente, se debiera prescindir, ante todo si se quiere evitar que la filosofía política de Hegel sea relacionada con un planteamiento metafísico.

La exigencia de que la voluntad auto-determinada exponga la estructura del Concepto es considerablemente más difícil de explicar porque está más íntimamente ligada con una tesis metafísica típicamente hegeliana. (Neuhouser, 2000, 40-41)

Por lo que hemos hecho notar en este apartado, sin embargo, cuando la ciencia filosófica del derecho se ocupa de su objeto, debe atender las exigencias de la Ciencia de la lógica: dejar de lado los prejuicios, comenzar por lo indeterminado y avanzar según el automovimiento de las categorías. Procediendo así, Hegel cree poder demostrar no sólo el modo en que se concibe y se realiza la libertad, sino también el hecho de que la razón anima el mundo ético. El espíritu lógico que subyace a la Filosofía del derecho, por lo tanto, no sólo es un rasgo peculiar de la propuesta hegeliana, sino que de ello depende la comprensión del mundo ético. 
Teniendo presente esta perspectiva, en lo que resta del trabajo revisaremos primeramente un crítica temprana que hizo Hegel a la filosofía práctica de Kant, al observar precisamente que partía de presupuestos y que se regía por una lógica unilateral temerosa de la contradicción, lo que dio como resultado una comprensión dualística de la libertad. Esa crítica se desarrolla en el ensayo sobre el Derecho Natural, de 1802. Sabemos que Kant es el interlocutor más importante de Hegel, y en el siguiente apartado encontraremos los primeros motivos que éste tuvo para considerar que el tratamiento kantiano de la libertad no se hacía cargo de sus propias contradicciones. 


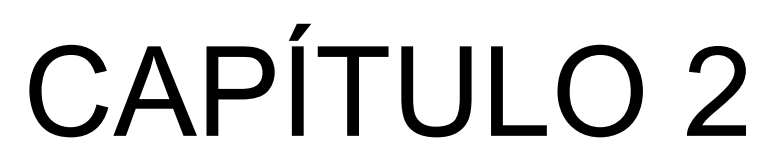

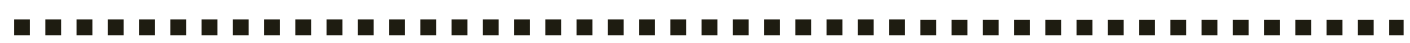

\section{PRIMERA CRÍTICA DE LA LÓGICA UNILATERAL}


En todo sistema dualístico, y muy particularmente en el kantiano, su defecto fundamental se da a conocer por la inconsecuencia de unir lo que un momento antes se ha declarado autosuficiente $y$, por tanto, imposible de unir.

Hegel, (Enc. $\S 60$, Nota)

La propuesta hegeliana relativa a las exigencias que una ciencia filosófica debiera atender nos permite observar que, cuando se parte de un principio preestablecido en la investigación filosófica, y cuando no se avanza en función del movimiento interior de las propias categorías, el punto de partida y la conclusión suelen afianzarse como la mera oposición de perspectivas o puntos de vista, como queda manifiesto en una larga serie de planteamientos en la filosofía política moderna y contemporánea que han adoptado la forma de algún tipo de dualismo o mera oposición. En este orden tenemos, por ejemplo, la oposición entre derecho natural y derecho positivo, entre el conocimiento empírico y el formal, los motivos internos y la legislación externa, entre un lenguaje normativo y uno descriptivo, entre el ser y el deberser, la necesidad y la contingencia, la voluntad y el arbitrio. Tenemos la confrontación entre las costumbres y la ley, lo privado y lo público, la identidad y la ciudadanía. Se suele oponer también la teoría y la práctica política; la mirada del observador y la del participante; las posturas cognitivistas que buscan la verdad y las que consideran que la política es una cuestión meramente pragmática; el contenido y los procedimientos. Hay confrontación igualmente entre quienes otorgan prioridad normativa al individuo (de donde habría de seguirse un Estado "neutral"), con quienes se la otorgan a la sociedad (de donde se seguiría un Estado "integrista"). Tenemos la pugna de la metafísica con el secularismo, y de las posiciones conservadoras con las progresistas..., entre muchos otros pares.

Aunque se trata de oposiciones que corresponden a diversas etapas y a distintos niveles de discusión, todas ellas parecen compartir una misma lógica, la lógica de la externalidad, la separación y la unilateralidad. En todas estas discusiones, el punto de partida siempre es una dicotomía en la que lo fundamental es la separación inicial entre dos principios o dos puntos de vista que se afianzan como algo auto-subsistente, dos principios que serían mutuamente excluyentes y en donde, mientras más se afirma uno de los extremos, en esa misma medida se rechaza el otro. 
No es difícil notar que, si bien las dicotomías que hemos enlistado se expresan con otros términos, una teorización sistemática de esta forma de pensar tiene a uno de sus exponentes modernos en Immanuel Kant, quien simultáneamente quiso deshacerse de la metafísica tradicional y asegurarse de que la libertad era posible, aunque fuese como un pensamiento; quien logró establecer las condiciones trascendentales del conocimiento y la autonomía del sujeto, pero bajo la exigencia de mantener separados un mundo fenoménico de uno inteligible, una causalidad natural y una causalidad libre, el fenómeno cognoscible y "la cosa en sí" incognoscible, la forma universal de la legislación moral y la materia o el propósito particular del acto, una moral pura y una antropología pragmática, la voluntad y el arbitrio, la moral y el derecho, el deber y la felicidad...

Es ante dicho panorama que, en el ámbito específico del espíritu objetivo, la filosofía política de Hegel plantea el reto de pensar filosóficamente la libertad, lo que en su sistema equivale a pensar bajo la guía de la razón y no sólo bajo la guía del entendimiento. Esto quiere decir que, más allá del contenido, la teoría o el principio que se tenga como sustento de la libertad (contenido que luego puede estar en pugna con otros), lo que debe guiarnos es el "concepto" y no sólo la "representación" de la libertad. En la terminología hegeliana, la "representación" sólo se refiere a la concordancia de una cosa existente con la noción que tenemos de ella; en tanto que el "concepto" se auto-produce atendiendo a su necesidad interna. En el Prólogo a la segunda edición de la Enciclopedia, Hegel hace un reproche a la filosofía que sólo se queda en el nivel del entendimiento, ignorando que “...tanto el sentido como la necesaria demostración de una definición sólo reside en su desarrollo y que de éste procede ella como resultado." (Enc., p. 64) En este tenor, si queremos pensar filosóficamente la libertad, lo que debe guiarnos es el concepto y la "Idea", que el autor entiende como la unidad entre lo pensado y su realización. En el caso de Hegel, como hemos visto, no se exige encontrar primeramente algún principio o contenido seguro que nos ayude a demostrar posteriormente que la libertad es algo posible en el ser humano; tampoco es indispensable mantener como distintos el uso teórico y el uso práctico de la razón, la razón y la sensibilidad, la voluntad y el arbitrio, ni una causalidad natural y una causalidad libre... Todo lo contrario, tal parece que su filosofía práctica se orienta precisamente a revisar aquella lógica irreductible de la externalidad, heredada por Kant.

Bajo un procedimiento que considera el más apropiado para una ciencia filosófica, Hegel quiere demostrar que la verdad de una cosa (en este caso de la libertad) no es ajena a 
su concepto ni al modo en que éste se produce y por medio del cual nos hacemos autoconscientes de ella. Quiere demostrar también que la verdad no radica en la parte, ni en la unilateralidad, ni en la mera confrontación de posturas, contenidos o principios, sino que toda oposición debe someterse constantemente a la fuerza de la negación, que es lo que la pone en movimiento.

En el presente apartado revisaremos la primera crítica que hizo Hegel a la lógica de la separación, de la externalidad y la unilateralidad. Dicho ejercicio se encuentra en uno de sus ensayos tempranos: Sobre las maneras de tratar científicamente el derecho natural... Antes de esto, sin embargo, nos parece indispensable reconstruir, aunque sea brevemente, las líneas generales de la propuesta de Kant para pensar la libertad, quien es el principal interlocutor de Hegel en este aspecto, y al que nos estaremos remitiendo una y otra vez, debido a la influencia que ejerce sobre nuestro autor.

\section{EL PLANTEAMIENTO DE KANT.}

1. Como uno de los principales resultados de la Crítica de la razón pura, Kant sostiene que "conocer" la libertad es algo imposible para la razón. En cambio, en esa misma obra quiso asegurarse de que al menos era posible "pensar" en ella. Los objetivos de su crítica, como puede intuirse, son la metafísica tradicional y el empirismo. La distinción kantiana entre lo que es conocer y lo que es pensar dice que el “...conocimiento de un objeto implica el poder demostrar su posibilidad, sea porque la experiencia testimonie su realidad, sea a priori, mediante la razón. Puedo, en cambio, pensar lo que quiera, siempre que no me contradiga...” ( $\mathrm{CrPu}$, B XXVIn) Quizá debamos anotar que esta posición inicial describe el doble y fundamental propósito de la Crítica de la razón pura de Kant en su conjunto: señalar los límites de la experiencia que la razón especulativa no debe traspasar $y$, al mismo tiempo, reservarle un sitio al pensamiento de la libertad. 
Y, ¿a qué se debe, de acuerdo con Kant, que no podamos conocer la libertad, pero sí pensar en ella? Para dar una respuesta, entra en juego de inmediato la conocida separación kantiana entre fenómeno y cosa en sí: “...no podemos conocer un objeto como cosa en sí misma, sino en cuanto objeto de la intuición empírica, es decir, en cuanto fenómeno." (CrPu, B XXVI) La referida distinción se afirma en el sistema kantiano como una solución tan irrenunciable que, de no aplicarse, nos advierte Kant, tendríamos que aceptar que la voluntad humana también está sujeta, como el resto de los objetos del conocimiento, a la causalidad natural, es decir, tendríamos que aceptar que no es libre. "En efecto, si los fenómenos son cosas en sí mismas, la libertad es insalvable...", porque entonces, la causa de todo lo que ocurre sería la naturaleza. ( $\mathrm{CrPu}, \mathrm{B} 564)$

He aquí por qué resulta forzoso para Kant el tomar a la voluntad en dos sentidos distintos: “...en su fenómeno (en las acciones visibles) como necesariamente conforme a las leyes naturales $y$, en tal sentido, como no libre, pero, por otra parte, (...) como algo perteneciente a una cosa en sí misma y no sometida a dichas leyes, es decir, como libre, sin que se dé por ello contradicción alguna." (CrPu, B XXVIII) En esto consiste, por lo demás, la solución de Kant a una de las antinomias en que incurre la razón, la llamada antinomia dinámica: "En el mundo hay causas libres", versus "No hay libertad, todo es naturaleza". La libertad es posible, afirma Kant, pero sólo si una vez tomamos a la voluntad como "cosa en sí misma" y otra vez como "fenómeno". Si acaso queremos demostrar que la voluntad humana es libre, que la voluntad es depositaria de una causalidad propia y que es independiente de la causalidad natural, entonces parece forzoso tomarla en estos dos respectos diferentes. Adicionalmente, a Immanuel Kant le resulta extraño el hecho de que la razón incurra constantemente en este tipo de contradicciones, le parece que va demasiado lejos, y entonces sugiere este tipo de soluciones, más bien propias del entendimiento, para salir de la contradicción.

Esta es la solución que a Kant le parece suficiente y aceptable por ahora (es decir, en el ámbito de la primera Crítica), pero que luego será utilizada también en la esfera de la moral, no importando que el ámbito de las "cosas en sí" es uno del que no pueda decir nada, salvo que "es", pero al que, sin embargo, se debe aceptar como "existiendo" realmente, como soporte del mundo fenoménico. 
2. En la segunda Crítica, por su parte, Kant busca explícitamente demostrar que la libertad es un principio que corresponde a la voluntad humana como causalidad. En otras palabras, aquí ya no se trata de salvar únicamente la posibilidad de pensar en ella sin caer en contradicción, sino de fundamentar la posibilidad de una voluntad "pura", es decir, basada exclusivamente en principios a priori: no en la experiencia, ni en la contingencia, ni tampoco en los dogmas de la metafísica tradicional. "Así, pues, la primera cuestión aquí es: si la razón pura basta por sí sola para la determinación de la voluntad, o si sólo como empíricamente condicionada puede ser ella un fundamento de determinación de la voluntad." (CrPr, p. 27) ${ }^{6}$ De cara a los planteamientos del empirismo, la finalidad que Kant persigue aquí es muy clara: demostrar que todos los principios prácticos que suponen un objeto o materia particular como fundamento de determinación de la voluntad son empíricos y no pueden, por ende, fungir como leyes prácticas, dado que pertenecen al principio del amor a sí mismo o la felicidad, que no es, a la postre, universalizable. La felicidad no puede fungir como principio de la moral o del derecho, nos dice Kant, porque no surge de la autonomía de la razón, sino empíricamente. El principio de la felicidad, entonces, puede darnos máximas, pero éstas no podrían servir como leyes de la voluntad.

En la segunda Crítica, a Kant le preocupa pues demostrar que la razón es práctica por sí sola, que la razón "tiene que poder determinar la voluntad mediante la mera forma de la regla práctica, sin la suposición de ningún sentimiento..." (Ibíd.: 41) Por eso sugiere que, para que una máxima pueda ser pensada como ley práctica universal, para que una ley tenga validez moral, ésta debe llevar aparejada su necesidad absoluta, y esto sólo se consigue cuando se basa en principios universales, cuando prescinde de toda materia e incluso de todo fin particular que haga las veces de su fundamento.

¿Y qué nos queda cuando hacemos el ejercicio de separar toda materia de una ley? ¿Qué nos queda cuando prescindimos de todo objeto de la voluntad que pueda ser tomado como fundamento de determinación? Lo único que nos queda, de acuerdo con Kant, es "la mera forma de una legislación universal'. (Ibíd.: 45) Esto significa que las máximas particulares de acción de un individuo pueden llegar a constituirse en leyes prácticas, pero sólo en la medida que eviten cualquier objeto, cualquier materia. Kant termina pues

\footnotetext{
${ }^{6}$ Se utiliza la traducción de Manuel García Morente, publicada por Espasa-Calpe.
} 
afirmando que el procedimiento para saber si una máxima de acción es apta o no de constituirse en ley práctica, reside en querer que dicha máxima se convierta en legislación universal. En esto consiste, como sabemos, la primera formulación del imperativo categórico: "Obra de tal modo que la máxima de tu voluntad pueda valer siempre, al mismo tiempo, como principio de una legislación universal." (Ibíd.: 50)

Sin embargo, una vez establecido lo anterior, el filósofo afronta dos nuevos problemas. El primero de ellos, encontrar cuál es el tipo de voluntad que se correspondería con este modo de determinación, es decir, el tipo de voluntad que sólo se conduce bajo la mera forma de una legislación universal y, por tanto, con independencia de la causalidad natural. A lo que Kant concluye que dicha voluntad es nada menos que la libertad, que se trata de la voluntad libre. Así, una voluntad libre es aquella "...para la cual la mera forma legisladora de la máxima puede servir ella sola de ley..." (Ibíd.: 48) El segundo problema consiste en saber cuál es exactamente el contenido de determinación de dicha voluntad libre, y Kant afirma que el contenido es precisamente la mera forma de la legislación universal y no otro.

Es aquí mismo donde Kant se pregunta por dónde comienza nuestro conocimiento de lo incondicionado, si es por la libertad o por la ley. Y, al respecto, descarta rápidamente que la libertad pueda ser lo primero de lo que tengamos conciencia. De lo que tenemos conciencia inmediata es, por el contrario, de la ley moral, sin la cual ignoraríamos que somos libres. Kant sostiene pues que un individuo solamente llega a juzgar que “...puede hacer algo, [en cuanto] tiene conciencia de que debe hacerlo..."; y es así como un sujeto reconoce en sí mismo la libertad. Vale la pena subrayar este aspecto de la fundamentación de la libertad en Kant, porque es uno de los motivos de la crítica de Hegel, para quien es inapropiado "deducir" la conciencia de la libertad a partir de un principio ajeno a ella misma. Es que aquí, ciertamente, Kant opera una suerte de inversión en el sentido del argumento, al proponer que la conciencia de la libertad "se deriva" de la conciencia del deber y no al revés. Adicionalmente, Kant sostiene que los conceptos prácticos relativos al deber son un hecho, algo dado, algo de lo que tenemos conciencia, algo que simple y llanamente debemos aceptar. "Se puede denominar a la conciencia de esta ley fundamental un hecho de la razón, porque no se la puede inferir de datos antecedentes de la razón, por ejemplo, de la conciencia de la libertad..." (Ibíd.: 52) Pero, en qué consiste este "hecho de la razón" es algo que el filósofo no detalla. 
Con todo, el hecho de que la voluntad pueda ser pensada como estando determinada exclusivamente por la forma de la ley (por el imperativo categórico), le permite a Kant demostrar que la razón pura práctica es legisladora por sí misma, auto-legisladora. Y es así como llega a lo que considera el único principio de la ley moral y del deber conforme a ella, al que denomina principio de autonomía: el sujeto es autónomo en la medida que puede darse a sí mismo una ley moral universal. En esto reside el sentido positivo de la libertad, ya que en la primera Crítica el pensamiento de la libertad era un mero límite.

Ahora bien, si el sujeto es legislador y se auto-impone la ley, ¿a qué se debe que la ley moral adopte la forma de un imperativo? A juicio de Kant, esto es así porque, aunque supongamos la existencia de una voluntad pura en el hombre, al mismo tiempo reconocemos que es un ser afectado por necesidades y causas motoras sensibles, por la causalidad natural. Por tanto, no se puede esperar en él algún tipo de voluntad "santa" en la que no habría contradicción alguna con la ley moral. Para un arbitrio patológicamente afectado, entonces, la ley moral se presenta como obligación, como compulsión hacia una acción que debe llamarse deber. Con todo, Kant recomienda que conservemos la idea de la "santidad" como idea práctica, como un modelo que hay que perseguir siempre, aunque sepamos que no lograremos alcanzarlo nunca. Y esto es, por cierto, lo único que le corresponde a los seres finitos: luchar de manera interminable contra sus propios impulsos naturales. (Cfr. Ibíd.: 53-54)

Immanuel Kant parte entonces del dato básico de que el ser humano es una mezcla problemática de naturaleza y razón, al tiempo que quiere asegurarse de que la moral pura es posible. Es por eso que introduce todavía otra distinción, esta vez entre la moral pura y la antropología pragmática. La primera tiene por objeto fundamentar racionalmente la moral y la segunda se ocupa de la experiencia, el carácter y el comportamiento contingente de los seres humanos. El sentido de esta distinción es que la moral pura no puede basarse en la antropología, pero sí aplicarse en ella.

Con fundamento en todo lo anterior, algunos comentaristas del filósofo han hecho notar que, a fin de cuentas, lo que a Kant le interesa no es tanto el averiguar cuál es el origen de las acciones, (si es la razón o son los impulsos naturales), sino el modo en que la razón y el sentimiento se conjugan a la hora de formar los motivos para actuar. Es por ello 
que Kant terminaría concentrando su atención en el "libre arbitrio", la instancia del sujeto que se ve trágicamente sometida, aunque no determinada, a diversas exigencias, unas que provienen de la naturaleza y las otras de la razón, y que es la instancia que realmente puede llegar a considerarse libre, en la medida que es la que "elige". Si puede decirse que somos libres, según esto, se debe precisamente a que nuestro arbitrio está sometido y tiene la posibilidad de elegir entre exigencias opuestas. Es el arbitrio el que decide si satisface los impulsos naturales u obedece a la ley moral. (Cfr. Serrano, 2004: 34)

La oposición básica entre la razón y la naturaleza vuelve indispensable pues que Kant ponga en un cierto nivel a la voluntad, ofreciendo leyes morales racionales, y en el otro al arbitrio, eligiendo los motivos para actuar. De aquí se sigue que la voluntad sólo "actúa" realmente por mediación del arbitrio; lo suyo no es actuar, sino formular leyes morales a priori. La voluntad sólo ofrece los criterios para distinguir entre el bien y el mal, pero el que elige a fin de cuentas es el arbitrio. $Y$ entonces tenemos la conclusión de que realmente no podría decirse que la voluntad sea libre, ni que actúe, ni que sea buena o mala...

...la voluntad, que no se refiere sino a la ley, no puede llamarse ni libre, ni no libre, porque no se refiere a las acciones, sino inmediatamente a la legislación concerniente a las máximas de las acciones... (...) Por consiguiente, sólo podemos denominar libre al arbitrio. (Metafísica...: 226)

Quiere pues decir que, para Kant, la libertad no es más que la facultad del arbitrio para "elegir" los motivos de la acción. Según esto, el ser humano es libre precisamente porque se ve "afectado", aunque no "determinado", por dos fuentes contrapuestas de motivos para actuar, y porque tiene la opción de "elegir" cuál de ellas adopta.

Este punto de llegada también será objeto de crítica por parte de Hegel, quien asegura que reducir la libertad al mero arbitrio es un engaño, ya que, de cualquier modo, solamente el elemento formal de la autodeterminación es inmanente al arbitrio, mientras que el contenido es algo dado. (Cfr. FD, §15, Observación). "En el arbitrio, el contenido no está determinado por la naturaleza de mi voluntad, sino por la contingencia." (Ibíd., Agregado). De modo que representarse la libertad como mero arbitrio es apenas un momento inicial.

De la noción que tiene Kant de la libertad como "libre arbitrio" se desprende también que la adecuación de nuestros actos a la ley es algo contingente que depende de la elección 
que haga el arbitrio. Estamos pues llamados a ser racionales y autónomos, pero el arbitrio puede elegir otra cosa.

Con respecto a esta brecha o relación de "contingencia" entre la ley moral y nuestros actos, conviene anotar desde ya que Hegel no querrá más tarde suprimir dicha contingencia. Lo que llama su atención, guiado por un planteamiento lógico distinto, no es la brecha entre la ley y nuestros actos, sino el interminable laberinto de instancias y postulados a los que Kant debe recurrir una y otra vez con el objeto de intentar armonizar lo que primeramente afianzó como un dato incuestionable: la oposición entre la razón y la naturaleza, la ley y la sensibilidad, la moral pura y la antropología, el deber y la felicidad, lo posible y lo real...

Para el entendimiento, la dificultad consiste en acabar con la separación que en algún momento hizo arbitrariamente entre las facultades del alma (el sentimiento, la voluntad) y llegar [de una vez] a la representación de que en el ser humano hay una razón única en el sentimiento, la voluntad y en el pensamiento. (Enciclopedia, § 471, Nota $)^{7}$

Como veremos más adelante, el procedimiento de Hegel es distinto. En su caso se trata de demostrar el modo en que la voluntad se auto-produce como libre, desde su forma más indeterminada hasta la más concreta. Aunque Hegel también tiene claro que este proceso de autoproducción es contingente, que puede lograrse o no, pero del que sin embargo el espíritu se hace conceptual e históricamente consciente por medio de las instituciones racionales modernas que hacen posible la libertad. La diferencia es que Hegel no parte de ningún hecho dado ineludible, como el de la existencia de dos ámbitos antagónicos (la razón y la naturaleza) fuera y dentro del sujeto mismo. Ese punto de partida es el que orilla a Kant a adoptar constantemente dos puntos de vista, dos perspectivas o dos respectos para salvar la posibilidad de la libertad, ya sea como "mero pensamiento" en el plano teórico, ya como "autonomía formal" en el práctico, o como simple "capacidad de elección" en el nivel pragmático. Adriaan Peperzak comenta este asunto del siguiente modo:

Mientras que Kant estaba primariamente preocupado por la diferencia radical entre, por un lado, la naturaleza y el valor de las "inclinaciones sensibles" sobre las cuales podían fundarse sólo imperativos hipotéticos y, por el otro lado, la naturaleza y el valor de la voluntad buena o racional, cuya autonomía genera el imperativo categórico, a Hegel le preocupa mostrar la unidad fundamental de ambas dimensiones. (Peperzak, 1989: 108-109)

\footnotetext{
${ }^{7}$ El agregado entre corchetes pertenece al traductor.
} 
Intérpretes contemporáneos confirman que, para entender la filosofía práctica de Kant, es preciso distinguir dos perspectivas, la del "espectador" y la del "participante". Una se relacionaría con el uso teórico y la otra con el uso práctico de la razón. Con esto ganarían sentido diversas inconsistencias aparentes del sistema kantiano. Hay planteamientos que no se entienden, se advierte, a menos que se tome en cuenta la perspectiva desde la cual se abordan. Por otro lado, hay que distinguir un plano "empírico" y otro "normativo" en los asuntos tratados por Kant. (Cfr. Serrano, 2004) Lo que no deja de ser llamativo es que los dualismos de Kant tengan que salvarse con otros dualismos.

En lo que llevamos expuesto de ambas Críticas, si bien no hemos hecho una reconstrucción exhaustiva de las ideas de Kant, ya están a la vista varios de los planteamientos que, a los ojos de Hegel, resultan inapropiados para un tratamiento filosófico de la libertad. Han aparecido dualismos que, desde una lógica crítica, resultarían insostenibles en su mera oposición, toda vez que carecen de la negación determinada que vuelve mutua e íntimamente dependientes a los términos involucrados en toda oposición. Es el caso de tener que considerar a la libertad a veces como fenómeno y a veces como noúmeno; el tener que considerar al ser humano como sujeto a dos mundos antagónicos, uno sensible y otro racional; el tener que pensar en una causalidad natural y una causalidad libre...

El otro elemento problemático es la aseveración kantiana de que sólo llegamos a tener noticia de la libertad en cuanto somos conscientes primeramente del deber, es decir, por medio de un principio ajeno o de un antecesor más primitivo que la libertad misma, a la cual se supone autónoma. ¿De dónde proviene ese deber que luego nos permite, de acuerdo con Kant, ser conscientes de la libertad? Más allá de afirmar que es un "hecho de la razón", algo dado, el filósofo no da explicaciones al respecto.

Han surgido también otros rasgos problemáticos, como la convicción kantiana de que la acción moral debe operar bajo la renuncia de toda materia, ateniéndose pues exclusivamente a la mera forma de la legislación universal. Hegel hará notar más tarde que esta conclusión de la filosofía práctica kantiana puede llegar a hacer imposible la determinación concreta en el actuar. Si el planteamiento kantiano fuese coherente, piensa Hegel, la determinación concreta sería inviable porque, si el único móvil de la acción moral 
ha de ser el querer cumplir la ley, cuando el sujeto se determine perderá en autonomía. ${ }^{8} \mathrm{Y}$ esto conduce a que la moral pura (y con ella la libertad en tanto autonomía formal), deba terminar siendo considerada un mero pensamiento, un mero principio regulativo de la razón en su uso práctico, un deber-ser. Y este es el tipo de conclusiones al que se llega cuando el tratamiento filosófico de la libertad comienza con la mera oposición de términos. En este caso, la oposición de los términos o los principios antagónicos que sirven de punto de partida no hace sino profundizarse en el transcurso de la investigación, no importando que el interés del filósofo consista en afianzar uno de ellos. En el caso de Kant, es claro el interés por dotar de primacía a la ley moral, frente a las exigencias de la sensibilidad, pero hasta el punto de que la acción concreta de un sujeto parece imposible, porque la sensibilidad no deja de ser nunca una externalidad a la cual tiene que renunciarse para llegar a ser libre.

Hemos encontrado asimismo la convicción kantiana de que debemos perseguir constantemente la perfección en el mundo fenoménico, pero asumiendo que se trata de un fin que no podemos (ni debemos) alcanzar jamás. Porque, si al actuar bajo la ley esperamos alcanzar algún bien, propósito, efecto, fin u objetivo determinado, significa que realmente no estamos siendo movidos por el puro respeto a la ley, sino por el principio del amor propio; y esto supondría que no estamos siendo ni autónomos, ni racionales. Porque, como piensa Kant, las únicas acciones que gozan de valor moral son las que se realizan por deber y, aun cuando se actúe por deber, el valor moral radica exclusivamente en "querer respetar la ley" y no en los fines o consecuencias que de esto se pueda derivar. (Fundamentación..., pp. 3739)

Ya tenemos a la vista, por último, la conclusión kantiana de que la libertad no debe ser atribuida a la voluntad, sino solamente al arbitrio en tanto es el que elige los motivos para la acción, de entre dos fuentes contrapuestas.

3. Conviene observar también las repercusiones que este andamiaje de la moral pura ejerce en el ámbito de lo político, donde Kant introdujo un giro significativo con respecto a la tradición del contractualismo. En varios de sus trabajos Kant se refiere también al hipotético "estado de naturaleza" que está marcado por la guerra (o al menos por su constante amenaza), por una libertad sin ley. También para él se trata

\footnotetext{
${ }^{8}$ De ello daremos cuenta en el cuarto apartado, al revisar la crítica de Hegel a la moralidad.
} 
de una situación en la que no existen tribunales que juzguen con base en el derecho y donde el medio para imponer el derecho es la fuerza. Ese es el estado que obligaría al ser humano a instaurar un estado de paz, un estado legal. Kant escribe en La paz perpetua que, de no ser por la autoridad que los obliga, los hombres realmente nunca le otorgarían a los demás la seguridad de no lesionarlos. $Y$ es por eso que todos los hombres que viven bajo influencias recíprocas están obligados a dejar el estado de naturaleza y a sujetarse a la constitución en un Estado civil-legal.

En ese tenor, la quinta proposición plasmada en Idea de una historia universal con sentido cosmopolita, afirma que el mayor problema de la especie humana es precisamente la instauración de aquella sociedad civil que administre el derecho en general; una sociedad en donde la libertad bajo leyes externas se vincule a una constitución civil plenamente justa que albergue la mayor libertad individual, pero que determine los límites para coexistir con la de los otros. En la primera Crítica, Kant lo había dicho del siguiente modo:

Una constitución que promueva la mayor libertad humana de acuerdo con leyes que hagan que la libertad de cada uno sea compatible con la de los demás (...) es, como mínimo, una idea necesaria que ha de servir de base, no sólo al proyecto de una constitución política, sino a todas las leyes. ( $\mathrm{CrPu}, \mathrm{B} 373)$

El hipotético estado de naturaleza encarnaría pues una situación propicia para la violencia en la que sólo existe un derecho privado sin el apoyo del orden civil. De acuerdo con este discurso, los individuos preferirían ingresar al orden civil, en vistas de que representaría un riesgo menor para sus propios intereses materiales: no por convicción, sino por cálculo. Desde la propuesta kantiana, sin embargo, en línea con la fundamentación de la moral pura, el cálculo estratégico es insuficiente para explicar la validez del orden legal. Por eso plantea Kant que la instauración de un orden civil es, ante todo, un deber de la razón práctica al que nos vemos obligados por la razón misma y no por nuestros intereses materiales. Para Kant, el hecho de preferir la libertad de los seres racionales (que se someten a una fuerza legal auto-impuesta), en lugar de la libertad sin ley, equivale a superar la barbarie, el primitivismo y la degradación de la humanidad. Por eso se dice que la política moral kantiana prescribe que todo pueblo se convierta en Estado de acuerdo a los conceptos jurídicos generales de la libertad, un mandato que se basa en el deber y no en la sensibilidad. Con el deber de establecer un orden civil legal ocurre pues lo mismo que con el establecimiento de la moral pura; aquí también el fundamento de determinación de la 
voluntad debe evitar toda materia empíricamente dada, todo objeto, y debe surgir exclusivamente de la obediencia a la ley.

Al abandonar por deber el estado de naturaleza, entonces, la única asociación humana que es un fin en sí misma, concluye Kant, es el orden civil en cuanto hace posible la formación de los individuos como seres libres bajo una legislación jurídica.

Con todo, no podemos dejar de advertir que la legislación jurídica también contiene un aspecto problemático en la propuesta de Kant, especialmente por su relación de externalidad con la moral. En un primer momento, Kant escribe que las leyes de la libertad son morales, pero si afectan a acciones externas y a su conformidad con la ley, solamente son jurídicas. La diferencia entre una legislación y otra radica en el móvil: aquella legislación que nos ordena realizar una acción porque es un deber y ese deber es el único móvil existente, esa es una legislación ética. La que no incluye el deber como móvil, en cambio, sólo es una legislación jurídica, por lo que, seguramente, requerirá de la "coacción".

Así las cosas, no obstante que inicialmente parece haberse superado la oposición entre el individuo egoísta y el orden civil, (al demostrar que éste último debe pensarse como auto-impuesto), la de Kant se presenta, al mismo tiempo, como una solución en donde difícilmente puede considerarse que la libertad se realiza en la configuración del orden civil vigente. Dado que el punto de partida de Kant es un ser humano atravesado por una relación de externalidad entre la razón y su propia naturaleza, el filósofo sabe que el derecho vigente difícilmente será atendido por el puro deber. El orden civil es una condición para la libertad, pero parece requerir necesariamente de la coacción. En una mirada de profundo pesimismo sobre la humanidad, Kant sabe que el derecho vigente difícilmente será concebido como una auto-imposición por parte de unos seres ciertamente racionales, pero cuyo arbitrio puede optar por el impulso natural. De allí que el derecho también requiera plantearse necesariamente en dos extremos: como ideal y como coacción. Sabiendo que es irrealizable, sólo sirve como un ideal y, sabiendo que los seres humanos elegirán lo sensible, sirve para coaccionar al arbitrio, para obligarlo a elegir lo racional. De lo contrario, los seres humanos nunca respetarán la autonomía y la dignidad de los otros.

Esta parece ser una consecuencia natural y explícita del concepto de libertad en Kant. En los términos de la primera Crítica, la libertad en cuanto causalidad racional sólo es 
"pensable" sin contradicción como perteneciente al mundo inteligible, aunque desconocido, de lo en sí. Mientras que, en la segunda Crítica, la libertad se fundamenta bajo el principio de autonomía de la voluntad, pero que consiste en determinarse exclusivamente por "la mera forma de la legislación universal", es decir, evitando toda materia en el actuar. De este modo, un mundo configurado según el tipo de libertad que Kant concibe no puede constituir más que un ideal, un deber-ser. El mismo Kant asegura que el mundo moral no es “...más que una idea, pero una idea práctica que puede y debe tener su influencia real sobre el mundo de los sentidos para hacer de éste lo más conforme posible a esa idea." (CrPu, B 836). Y, mientras tanto, lo que queda es ejercer la coacción en este mundo fenoménico, a fin de coordinar los arbitrios.

Según habíamos adelantado, entonces, la filosofía práctica de Kant está atravesada por esta serie de oposiciones irremediables. De resolverse, de mostrar que cada parte de la oposición sólo es explicable por su relación con la otra, toda la propuesta de Kant perdería sentido. Para él es un requisito distinguir la inevitable pervivencia independiente e incompatible entre dos mundos, el fenoménico (donde los seres humanos no son más que un cúmulo de impulsos, deseos, intereses y necesidades; donde están sujetos a la causalidad natural y por tanto es preciso coaccionarlos), y uno inteligible o nouménico (donde puede pensarse que son libres, racionales y autónomos). Para Kant es igualmente un requisito separar el uso teórico del uso práctico de la razón: cada uno actúa por su lado y cada uno tiene ciertos límites y ciertas posibilidades. En el uso teórico, la razón pone sólo la estructura formal de los fenómenos, pero requiere de la intuición para conocerlos cabalmente; mientras que en el uso práctico, la razón es legisladora, aunque en un plano puramente formal, universal.

Robert Pippin sugiere que habría sido precisamente este cúmulo de dualismos, propios del sistema kantiano, lo que estimuló la prolífica discusión que caracteriza la fase del idealismo alemán que va desde Reinhold hasta Hegel, pasando por Jacobi, Fichte y Schelling, cada uno reaccionando a su manera al mismo desafío. Todos estos pensadores habrían aceptado los aspectos centrales de la crítica de Kant al empirismo y a la metafísica tradicional, pero estarían interesados en revisar internamente el sistema kantiano que, habiendo postulado la existencia necesaria e incognoscible de un ámbito de lo "en sí", no hacía sino abrir la puerta al escepticismo y a la fe. En el caso específico de Hegel, esto es lo 
que habría motivado la construcción del idealismo absoluto. (Pippin, 1997: 130-131) La observación del comentarista parece atinada, lo que puede constatarse desde los textos tempranos de Hegel, como el que revisaremos a continuación.

\section{EL ENSAYO SOBRE EL DERECHO NATURAL, PRIMERA CRÍTICA DE LA LÓGICA UNILATERAL.}

En 1802 Hegel publicó un ensayo que no forma parte del sistema, pero en el que ya se ocupa filosóficamente del mundo ético, en un intento por superar los planteamientos del empirismo y del idealismo trascendental. Allí encontramos ya una clara postura crítica frente a la lógica de la separación y la externalidad que caracteriza tanto a la filosofía de Kant, como al contractualismo en su conjunto. Nos referimos a Sobre las maneras de tratar científicamente el derecho natural... ${ }^{9}$

En esa pequeña obra, el blanco de su crítica lo constituyen los teóricos del Derecho Natural, la filosofía práctica de Kant y las ciencias del Derecho Positivo, a quienes reorganiza en "ciencias empíricas", "ciencias formales" y "ciencias positivas", respectivamente. Para efectos prácticos del presente trabajo sólo vamos a revisar lo relativo a las primeras dos tradiciones. Hegel considera que a pesar de la aparente diferencia entre una y otra, ambas posturas representan formas no-científicas de tratar el derecho. Las ciencias empíricas se caracterizan por la despreocupada mezcolanza de la intuición empírica y lo universal, y las ciencias formales por la oposición absoluta hacia lo real; pero, a los ojos de Hegel, los ingredientes de ambas tradiciones son los mismos, a saber: los conceptos empíricos y la intuición como cosas independientes.

En dicho ensayo encontramos, además, en un estado incipiente, buena parte de las ideas que Hegel desarrolla dos décadas más tarde en la Filosofía del Derecho; también por eso es pertinente recuperarla. Quizá sólo debamos advertir que entre el ensayo sobre el Derecho Natural y la Filosofía del Derecho se dio un importante giro en el pensamiento de

\footnotetext{
${ }^{9}$ Se utiliza la traducción de Dalmacio Negro Pavón, publicada en Editorial Aguilar. En adelante citaremos este ensayo con las siglas $D N$.
} 
Hegel, hacia la construcción del idealismo absoluto, lo que le permitió distanciarse también del romanticismo, todavía notorio en el momento de escribir el ensayo que ahora vamos a comentar. Por otro lado, si no nos remitimos a Fe y saber ${ }^{10}$, (que apareció por la misma época y que tiene un carácter similar al ensayo sobre el Derecho Natural, es decir, una primera reacción ante los dualismos que Hegel encuentra en la filosofía de Kant), se debe a que Fe y saber se ocupa básicamente de la filosofía teórica y muy poco de la filosofía práctica.

\section{Crítica de las ciencias empíricas del Derecho.}

Hegel constata primeramente que, en el esfuerzo de las ciencias empíricas, el derecho ya es considerado al menos una ciencia filosófica, una parte esencial de la filosofía; pero que, al mismo tiempo, ha sido privado de lo filosófico de la filosofía, es decir, se le mantiene como algo independiente de la Idea. $\mathrm{Y}$ este es un destino inapropiado, piensa Hegel, sobre todo cuando se considera que en su sistema filosófico, si algo posee verdad es precisamente la Idea, es decir, la unidad entre lo pensado y sus determinaciones. Sucede pues que, abordado desde la perspectiva de las ciencias empíricas, el derecho, como otras ciencias particulares, se ve obligado a reconocer que su principio científico sólo puede provenir de la experiencia empírica, renunciando con esto a ser una ciencia verdadera. Cabe anotar aquí que la superación del empirismo es un avance que Hegel reconoce a Kant y que comparte con él. Recordemos que, para Kant "aunque todo nuestro conocimiento comienza con la experiencia, no todo se origina en ella". Si algo le reprocha Hegel a Kant más tarde, es precisamente el haber retornado al empirismo, al afirmar que los conceptos son sólo formas vacías que, para ser cabales, requieren de la intuición sensible como de algo distinto y complementario.

En las ciencias empíricas del derecho, nos dice Hegel, lo científico se reduce a la aglomeración de múltiples cualidades. Como consecuencia, suele hacerse pasar por esencial a una determinación que realmente es parcial. Se convierte a una singularidad determinada en el fin y la esencia del todo. Pero, a falta de la necesidad interior, que sólo

\footnotetext{
${ }^{10}$ Traducción de Glauben und Wissen que, al igual que el ensayo sobre el Derecho natural, fue publicado en el Kritisches Journal der Philosophie, el diario filosófico que Hegel y Schelling dirigieron juntos temporalmente.
} 
radica en la Idea, una tal determinación parcial no está en relación necesaria con las otras, de manera que cada una de ellas podría reivindicar, sin problema, su independencia del resto. Es por eso que, de modo arbitrario, el empirismo eleva sus experiencias a la universalidad y luego persigue las consecuencias que se siguen de ellas..., hasta que un nuevo material empírico se contrapone con el anterior, teniendo ahora éste el derecho de ser pensado y tomado como principio, y obligando a dejar abandonada la determinación precedente.

Lo que Hegel tiene aquí en mente son, sin duda, las diversas teorizaciones del "estado de naturaleza". Sabido es que Hobbes, Locke, Rousseau e incluso Kant, destacaron algún aspecto de la naturaleza humana para explicar desde allí la necesidad de transitar a un orden civil por medio de un contrato. En este escrito temprano, Hegel denuncia que semejante procedimiento obedece más a una psicología empírica que a un esfuerzo filosófico. Por otro lado, exhibe también que lo que primeramente se afirma como necesario, posteriormente se reconoce como algo no real, algo meramente imaginado y como cosa-delpensamiento; "allí como una ficción, aquí como una simple posibilidad, lo que constituye la más violenta contradicción." (DN, p. 16) Hegel se refiere con esto al planteamiento de los propios teóricos del contractualismo, quienes también afirman que el "contrato social" no es más que una hipótesis, un modelo normativo, un recurso de argumentación por medio del cual podría llegarse a suponer que el Estado es fruto de nuestro consentimiento subjetivo.

Hegel señala entonces que el tratamiento empírico del derecho carece de un criterio para identificar la frontera entre lo accidental y lo necesario, lo que debiera permanecer y lo que debiera suprimirse, tanto en lo que toca al estado de naturaleza como a las abstracciones sobre la supuesta naturaleza del ser humano.

Es por eso que, al referirse al Estado y a fin de explicarlo como una formación necesaria, la ciencia empírica del derecho termina colocando arbitrariamente un rasgo apropiado para ordenar el caos que se representó como lo inicial. (Ibíd.: 17) Sucede pues que, en el discurso de la ciencia empírica del derecho, la unidad positiva tiene que añadirse sobre la multiplicidad, pero como algo diferente y extraño. Hegel hace notar entonces que, en las teorías del "estado de naturaleza", el estado se postula efectivamente como un producto de la fragmentación. Sin embargo, al igual que en la física, si sólo nos atenemos al principio de la absoluta multiplicidad, la unidad misma ya sólo puede presentarse en forma 
de contactos superficiales, así como en vínculos y mezcolanzas ligeras entre las partes que primeramente han sido afirmadas como existiendo en forma atomizada. $Y$ es precisamente a ese tipo de "unidad" a lo que el contractualismo denomina Estado:

Se trata pues de una multiplicidad de lo dividido o de relaciones y, en la medida que la unidad se pone como todo, se puede poner el nombre vacío de una armonía externa y sin forma, bajo el nombre de sociedad y de Estado. (Ibíd.: 19)

En un Estado constituido así, empero, la relación entre gobernantes y gobernados también está marcada por la externalidad, por relaciones de dominio y obediencia. En un estado que se justifica así, el derecho se presenta necesariamente como algo extraño a los individuos, un poder ante el cual simplemente deben ser sumisos. $Y$ todo, advierte Hegel, debido a que el principio de la ciencia empírica excluye desde el comienzo la unidad absoluta de lo uno y lo múltiple, la unidad de la identidad y la no-identidad. Hegel sostendrá, por su parte, que la eticidad orgánica es el momento de la unidad absoluta que soporta en su interior la oposición de la unidad y la multiplicidad, constituyendo así la totalidad absoluta, es decir, aquella que no requiere de nada externo a sí misma para ser comprendida. (Cfr. ibíd.: 21) Aun cuando en este momento Hegel todavía no llega a la comprensión de la eticidad como fruto de un despliegue dialéctico de las formas de existencia de la libertad, al menos ya está claro que la vida ética, cuya principal institución es el Estado, no debiera configurarse como un poder extraño que sólo restringe la supuesta "libertad natural" de los individuos, sino todo lo contrario: como un conjunto de instituciones que le permite a los individuos salir de esa naturalidad y llegar a ser plenamente humanos. Pero este resultado no es posible cuando, de antemano, se ha tomado al individuo como el principio explicativo del Estado.

\section{Crítica de las ciencias formales del Derecho.}

A diferencia de las ciencias empíricas, las ciencias formales se aferran a lo que Hegel denomina la "pura infinitud", entendida como oposición absoluta a lo múltiple, a lo finito. Toda vez que afirma sus principios formales como lo absoluto y a priori, la ciencia formal del derecho (entiéndase Kant), comienza por excluir a lo empírico de su "aprioridad" y de su ciencia. Como consecuencia, la razón considera que lo real está fuera de ella. De dicha separación proviene también, ya en el ámbito de la filosofía práctica, la externalidad entre 
vida ética y naturaleza, expresada de otro modo como libertad y necesidad. Pero Hegel hace notar desde este momento que, visto desde el marco de la razón y no sólo desde el entendimiento, la necesidad podría entenderse como libertad negada, y la libertad como necesidad negada porque, cuando este y otros pares de términos son puestos en movimiento por la fuerza de la negación determinada y la contradicción, se demuestra que se implican el uno en el otro, que cada uno requiere del otro para ser lo que es; pero este movimiento es uno que la ciencia formal, que se queda en el nivel del entendimiento, no hace. Como sabemos, en el marco de la Crítica de la razón pura, la dialéctica goza de un tratamiento marginal por parte de Kant, quien prefiere adoptar respectos, puntos de vista o perspectivas distintas para referirse al mismo objeto, (una vez como fenómeno y otra como cosa en sí), antes que afrontar las contradicciones en que incurre la razón y constituyen al objeto mismo.

Este primer aspecto de la crítica de Hegel a Kant amerita que nos detengamos por un instante. Tanto en el ensayo relativo al Derecho Natural que venimos comentando, como en Fe y saber, nuestro filósofo señala que el afianzamiento de "lo real fuera de la razón" es una característica distintiva del dualismo en la filosofía de Kant. En efecto, Hegel hace notar que, al igual que la metafísica tradicional, Kant mantiene como cosas distintas al "ser de la intuición" y al "pensar del entendimiento"; no llega pues a percatarse de su unidad en el pensamiento. El empirismo había sido incapaz de explicar el modo en que el sujeto reúne o sintetiza la multiplicidad de sensaciones; es decir, ignoraba el concepto. En tanto que la metafísica tradicional pretendía que podemos conocer sin recurrir a la experiencia. Kant dio un paso significativo al demostrar que es el sujeto el que pone las condiciones trascendentales que hacen posible el conocimiento, pero, a fin de cuentas, también concluye que dichas condiciones trascendentales sólo son la estructura formal del fenómeno y que, además, sólo sirven para conocer fenómenos, pero no lo que las cosas son en sí mismas. De acuerdo con Kant, el sujeto cognoscente sólo produce pues la forma en que se nos presenta lo real. De suerte que, como advierte Hegel, la autosuficiencia e independencia entre el "ser de la intuición" y el "pensar del entendimiento" no hacen sino profundizarse en la filosofía de Kant: por un lado está el yo con sus condiciones trascendentales y por el otro la multiplicidad de lo sensible y el ámbito de lo en sí.

En torno a este asunto, algunos comentaristas de Kant han hecho notar recientemente que la crítica de Hegel habría sido inadecuada, toda vez que la separación 
establecida por Kant no se ajusta necesariamente a la que encuentra Hegel entre el "ser" y el "pensamiento". (Cfr. Guyer, 1993: 179) Es el caso de Paul Guyer, quien ratifica que, si bien Kant afirma la universalidad del conocimiento como algo a priori o independiente de la experiencia, también sostiene que dicho conocimiento se restringe al modo en que las cosas aparecen para nosotros. Guyer confirma que el argumento kantiano se dirige básicamente a superar el empirismo, así como a evitar las pretensiones de la metafísica tradicional; y esta es una motivación que Hegel no habría tomado en cuenta. (Cfr. Ibíd.: 172)

De acuerdo con Guyer, entonces, la crítica que hace Hegel a Kant proviene de una lectura sesgada que reinterpreta la terminología de Kant bajo distintos presupuestos. (Cfr. Ibíd.: 181) La de Hegel sería una crítica externa en la que, además, el comentarista no encuentra que Hegel haya demostrado suficientemente el modo en que los conceptos podrían hacerse de conocimiento sin recurrir a la intuición sensible, ni el modo en que el ser y el pensamiento, lo particular y lo universal, podrían estar unidos. (Cfr. Ibíd.: 205) Al igual que otros autores contemporáneos, entonces, Paul Guyer no ve en la postura de Hegel otra cosa que afirmaciones metafísicas que carecen de demostración. El comentarista concluye que, ignorando los límites señalados por Kant, Hegel querría eliminar la contingencia que supone la separación entre las dos fuentes de conocimiento.

La reacción de Paul Guyer, sin embargo, reduce su atención a Fe y saber, dejando de lado toda la argumentación sobre ese problema central en la Fenomenología del espíritu y en la Ciencia de la Lógica. Es decir, el comentarista tampoco atiende el desarrollo sistemático de la argumentación hegeliana. No atiende, por ejemplo, que la Fenomenología tiene por objetivo superar precisamente la oposición entre la conciencia y su objeto, y que toda la Ciencia de la Lógica despliega las determinaciones del pensamiento inmediato del puro ser, una vez demostrado que el ser y el pensamiento comparten una misma estructura lógica.

Por otro lado, Guyer considera básicamente el componente epistemológico de la crítica de Hegel a Kant, dejando entrever que esto pondría también en entredicho la reacción de Hegel ante la filosofía práctica de Kant. Pero la crítica de Hegel al planteamiento de Kant en la filosofía práctica no sólo se refiere a la separación entre el pensamiento y el ser, sino a toda otra serie de problemáticas. Incluso si se acepta que la crítica de Hegel fuese injusta en lo que respecta al dualismo entre concepto e intuición, habría que decir que la concepción 
kantiana de la libertad está marcada por otras debilidades, desde su punto de partida hasta sus conclusiones.

Un aspecto que sí resulta de vital importancia para la concepción kantiana de la libertad y al que se presta menos atención es el ámbito de lo "en sí". Sabemos que todos los dualismos de la filosofía de Kant requieren, a su modo, de dicho ámbito, e incluso los límites impuestos por Kant a la metafísica tradicional dependen del postulado de que, tras los fenómenos, hay cosas en sí a las que la razón no puede acceder. Pero el ámbito de lo en sí es un mundo indeterminado e indeterminable al que no puede accederse ni por medio de la intuición, ni por medio de las categorías del entendimiento, aunque tengamos que aceptarlo como algo efectivamente existente. Kant termina diciendo por eso que lo en sí es un mero límite. Pero incluso esta salida tendría consecuencias en su propia filosofía práctica. Si lo en sí es un mero límite, ¿qué sucede con aquellas ideas tan indispensables para dotar de sentido a la moral kantiana, es decir, Dios y la inmortalidad? ¿Cómo concilia Kant la centralidad de que gozan esas entidades en la moral pura, con la aseveración de que lo en sí, ámbito al cual pertenecen, representa un mero límite? (Cfr. Pérez, 2008: 30)

Lo que esto nos hace pensar es que, donde Kant recurre al postulado de las cosas en sí para "acomodar" una serie de dualismos y evitar que la razón entre en contradicción, Hegel percibe que la contradicción es precisamente el componente más valioso de la razón y de lo real, porque de ella depende su movimiento. $Y$, cuando se asume la contradicción, ya no hace falta echar mano de ningún tipo de ámbito que sería evasivo del mundo humano o de la propia razón, en cualquiera de sus usos. No es que la razón elimine pues la contingencia que comporta el conocer o el actuar, es que también se hace cargo de dicha contingencia.

Volviendo al ensayo del Derecho Natural, cuando Hegel procede a revisar directamente el pensamiento de Kant, nos recuerda que, para Kant, la razón práctica debe renunciar a toda materia de la ley y que sólo puede convertir en ley suprema la forma de la aptitud de la máxima. Se trata de la abstracción absoluta de toda materia de la voluntad porque, de adoptar un contenido cualquiera, se caería en la heteronomía. Hegel revira ante esto que, dado que en la filosofía práctica se trata de saber qué es el derecho y qué es el deber, la pregunta, lo mismo que la acción, nos remiten al contenido de la ley ética, no sólo a su forma. En la filosofía formal de Kant, empero, la esencia de la voluntad pura y de la razón 
pura práctica consiste en abstraerse de todo contenido, por lo que resulta contradictorio, en sí mismo, buscar allí una legislación ética, ya que ésta tendría necesariamente un contenido.

En efecto, según habíamos apuntado, Kant concluye que, para que una máxima de la voluntad pueda valer simultáneamente como principio de una legislación universal, esta ley fundamental de la razón pura práctica requiere, de todos modos, que se ponga alguna determinación como contenido de la máxima de la voluntad particular, cosa que la moral pura kantiana parece rechazar simultáneamente. En vistas de lo anterior, Hegel observa que cualquier determinación particular gozaría de aptitud para ser recibida en la forma del concepto y, por tanto, no habría nada que no pudiese llegar a convertirse en una ley ética, incluso si se trata de máximas sobre asuntos poco relevantes para la moral. (Ibíd.: 36)

En este caso tampoco ignoramos la defensa que algunos intérpretes contemporáneos han hecho de Kant. Según esto, no es verdad que el imperativo categórico carezca de contenido. Allí está por ejemplo la otra formulación del mismo: "obra de tal modo que uses la humanidad, tanto en tu persona como en la persona de cualquier otro, siempre como un fin al mismo tiempo y nunca solamente como un medio." En la filosofía práctica de Kant, aquello que se refiere a las necesidades e inclinaciones del hombre, aquello que puede ser sustituido por algo equivalente..., eso tiene un precio; pero lo que constituye un fin en sí mismo, lo que está por encima de todo precio, lo que sólo tiene valor interno..., eso es la dignidad humana. De tal manera que el imperativo categórico no carece completamente de contenido y es inadecuado suponer que en él cabría cualquier cosa. La dignidad humana representa un contenido imposible de ignorar.

Se dice también que el imperativo categórico contiene un principio de justicia universal, cuando nos manda actuar de manera libre, racional y autónoma. Por ende, el imperativo nos ordena reconocer y respetar a los otros sujetos que también se comprometen a actuar racionalmente; es decir, el imperativo categórico pone las condiciones para la práctica de los agentes morales autónomos. (Cfr. Sedgwick, 1996: 583) He aquí el contenido del imperativo categórico que pondría en entredicho la crítica que despertó en Hegel.

Pero si se acepta que el imperativo categórico tiene un contenido, también debiera advertirse que Kant decidió fundamentar la ley moral y la libertad, como el actuar bajo "la mera forma de una legislación universal". Si el principio de la dignidad humana, el mandato 
de actuar racionalmente o el reconocimiento de los otros como seres igualmente autónomos es un contenido, una materia o un objeto del imperativo categórico..., también debe ser claro que el único contenido de determinación de la voluntad libre, de acuerdo con Kant, es la mera forma de la ley, que lo único moralmente válido debe ser el querer cumplir la ley, la ley por sí misma. Habría que reconocer entonces que el mandato de actuar racionalmente, respetar y reconocer la dignidad y la autonomía de los otros es un contenido secundario, cuando lo que importa, lo moralmente válido es únicamente el "querer cumplir la ley" o el actuar bajo "la mera forma de una legislación universal". De este modo, incluso cuando se acepta que el imperativo categórico tiene un contenido, el problema de la indeterminación seguiría vigente.

Parece pues que la relación problemática entre abstracción absoluta y determinación sigue vigente incluso si se decide colocar el mandato de actuar racionalmente, el principio de la dignidad humana o el reconocimiento de la autonomía de los otros como contenido del imperativo categórico. $Y$ todo, porque el punto de partida de Kant es el hecho básico de que la naturaleza y la razón humana guardan una relación de externalidad incluso al interior del sujeto mismo, y esto lo lleva a sostener que, para ser autónomos, el arbitrio debe elegir los mandatos de la moral pura, ignorando cualquier contenido material.

Como Peter Steinberger comenta, lo que la crítica de Hegel señala es que lo correcto o incorrecto de una acción no es únicamente una cuestión de forma -un asunto sobre si el móvil de la acción proviene de los impulsos sensibles o de la razón-, sino también una cuestión del contenido, es decir, de lo que realmente se hace. Mientras que Kant se empeña en definir la moralidad como la búsqueda de "la naturaleza de la acción moral per se", Hegel piensa que ésta también debiera incluir, pero de modo mucho más importante, un esfuerzo por orientar la acción concreta. (Cfr. Steinberger, 1988: 150)

Hegel critica también que el imperativo categórico, planteado así, no nos daría motivos para actuar, ya que, cuando el sujeto debe cumplir un deber en función de la mera forma de una legislación universal, de cualquier modo es él quien debe seguirlo, un sujeto que no puede prescindir de sí mismo, de su formación, de la carga de deseos y necesidades particulares que lo identifican, de su propio interés.

...hay que considerar la determinación del sujeto: quiere algo que está fundado en él; quiere satisfacer su placer y sus pasiones. Pero el bien y lo justo constituyen también un contenido, no ya meramente natural, sino puesto por mi racionalidad: mi libertad 
convertida en contenido de mi voluntad es una determinación pura de mi propia libertad. El más elevado punto de vista moral es, por lo tanto, encontrar la satisfacción en la acción, y no permanecer en la ruptura entre la autoconciencia del hombre y la objetividad del hecho. (FD, §121, Agregado)

En el caso de Kant no parece existir una respuesta satisfactoria para esta necesidad de hacer coincidir lo universal y lo particular. Por todo esto, Hegel prosigue diciendo en el ensayo sobre el Derecho Natural que, aparentemente, para la razón práctica formal kantiana realmente sería indiferente cuál determineidad es la que toma la forma de lo absoluto, de la ley, del deber. $Y$ advierte que, a fin de cuentas, el formalismo kantiano también termina por hundirse en la necesidad empírica, participándole la apariencia de una verdadera absolutez. (Cfr. DN, p. 14). Al libre arbitrio sólo le toca elegir entre diversas determineidades opuestas, y sería una mera falta de habilidad el no poder encontrarle un fundamento semejante a cualquier máxima para la acción.

Anclado en la oposición, propia de las ciencias formales del derecho, entre finitud e infinitud, Hegel descubre también desde esta obra temprana el motivo de que el derecho y la moral aparezcan como elaboraciones independientes en la filosofía kantiana, incluso como ciencias distintas: una de ellas relativa al ser-uno del concepto puro y del sujeto (la moral), y la otra relativa al no-ser-uno (el derecho). Lo ético se separa en moralidad y en legalidad, pero sin que ninguna de las dos ciencias llegue a ser absolutamente positiva 0 verdaderamente ética. (Ibíd.: 45-46) El problema que Hegel avista con dicha relación de externalidad es que, si las dos resultan ser completamente necesarias, es preciso establecer que el concepto puro y el sujeto del deber y del derecho no deben pertenecer a una sola de ellas. De suerte que la ley moral, la libertad universal de todos, se opone a la conciencia real, al sujeto, al ser racional, a la libertad singular. De allí que resulte necesario echar mano de la “compulsión", lo que a los ojos de Hegel representa un retroceso en el principio de la autolegislación kantiana. El recurso a la "compulsión", puesta como algo exterior a la libertad y necesaria para hacerla posible y para adecuar la "libertad singular" con el derecho, advierte Hegel, deja a la libertad sin fundamento, ya que, de acuerdo con su definición formal, la libertad debería consistir precisamente en que no posee nada exterior en absoluto, en que es autónoma. 
Comentando este pasaje, Dalmacio Negro Pavón nos dice que la crítica de Hegel se dirige al hecho de que, una vez excluida la auto-imposición por parte de los sujetos, (la motivación para actuar), lo único que puede esperarse es la obligación legal como una suerte de causalidad mecánica. Hegel propone en cambio que, si bien el derecho abstracto y la moralidad son dos configuraciones distintas de la libertad, no por ello son absolutas, independientes o auto-suficientes, sino que la una integra y conduce necesariamente a la otra, además de superar su mera oposición en el momento de la eticidad; de allí la importancia de que el derecho (la libertad realizada) se exprese además como vida ética. En este caso, la coerción sólo será un recurso positivo secundario tendiente a confirmar el derecho cuando llegue a ser negado, y a reconocer al ciudadano como un ser racional en todo momento, incluso cuando comete delito.

Cuando Hegel se ocupa filosóficamente de la libertad, coincide con Kant en que el derecho debe provenir del consentimiento de los sujetos, pero su planteamiento llega a ser algo más amplio en este punto, porque su demostración implica reconocer que el principio de auto-legislación nos precede en cuanto individuos. Mientras que Kant ubica el consentimiento y la capacidad auto-legisladora en el plano puramente formal y subjetivo, el planteamiento hegeliano permite reconocer que el derecho objetivo también es fruto de un proceso colectivo de auto-legislación. En el planteamiento hegeliano, el proceso de autolegislación es, además de subjetivo, histórico y colectivo porque, como advierte Pippin, resulta difícil imaginarse la existencia de un sujeto previo a toda norma objetiva, que sería el productor originario de una regulación que se auto-impone más tarde. Hegel demuestra que la formación y el auto-sometimiento es un proceso gradual, colectivo e histórico; por eso requiere de la comunidad ética, que es la que se reconoce como independiente de la naturaleza y de lo sobre-natural, y que se reconoce autora de sus propias restricciones. (Pippin, 2000: 192-5) Debido a una perspectiva lógico-filosófica distinta, ni siquiera los impulsos e inclinaciones pertenecen en lo absoluto a una naturalidad simplemente dada en el planteamiento de Hegel, porque incluso en el nivel de los impulsos hay un trabajo de la voluntad para organizarlos y buscar su satisfacción, siempre bajo la mediación de una eticidad que nos precede y nos forma como seres libres. El individuo no puede separarse pues de la eticidad ni siquiera en el nivel de los impulsos naturales.

El desenlace del planteamiento hegeliano en la "vida ética" no proviene, entonces, de la exaltación ingenua de las costumbres o la tradición. Por el contrario, en confrontación directa con la Escuela Histórica (representada en su época por Savigny), que sí adoptaba 
una postura de ese tipo, Hegel defiende que en una Constitución política no debe reconocerse como válido más que aquello que se conforma al derecho de la razón. En el planteamiento de Hegel, la fuente última del derecho debe ser siempre la razón que se actualiza. (Cfr. Bobbio, 1989: 383) Eso está claro desde el comienzo de la Filosofía del Derecho: "la explicación y la justificación históricas no pueden ser ampliadas hasta alcanzar el significado de una justificación válida en y por sí." (FD, §3)

En breve, en el ensayo sobre el Derecho Natural, Hegel reconoce lo avanzado por Kant, pero al mismo tiempo critica que, entre otras cosas, haya confinado la libertad al momento de la pura autonomía formal subjetiva, lo que da cuenta de una lógica unilateral que se aferra en un punto del movimiento del concepto. La crítica se refiere pues a una insuficiencia, al no proseguir con la dinámica de la negación de toda determinación. 


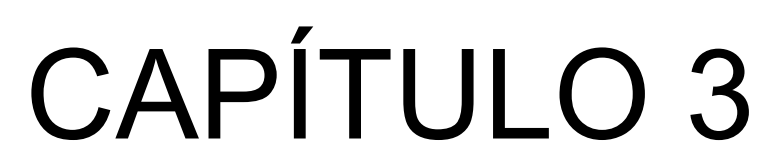

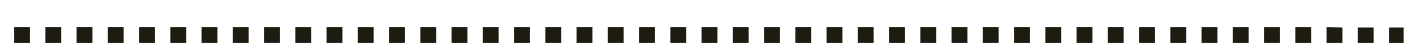

\section{EL CONTENIDO DE LA VOLUNTAD}


Una vez revisado el planteamiento de Immanuel Kant en torno a la fundamentación de la libertad, y una vez expuesta la primera reacción que esto despertó en Hegel, nos parece que estamos en condiciones de revisar el modo en que este último propone desplegar el concepto de voluntad libre. Para ello, primeramente dirigiremos nuestra atención a la parte introductoria de la Filosofía del Derecho. La intención, como hemos dicho, es observar directamente el modo en que las exigencias de la Ciencia de la Lógica son atendidas en dos momentos clave de la ciencia filosófica del derecho: cuando se ocupa del contenido de la voluntad y cuando se ocupa de las configuraciones de la libertad en su existencia. Aquí abordaremos el primero de dichos momentos.

En las primeras líneas del Prefacio a la FD, Hegel nos hace saber que la obra tiene como propósito desarrollar de modo sistemático los conceptos fundamentales "sobre esta parte de la filosofía" que ya habían sido tratados en la Enciclopedia de las ciencias filosóficas. La diferencia entre un texto y otro es que, mientras la Enciclopedia fue pensada como guía para los cursos en la universidad, la publicación de la FD hizo necesario ampliar el texto mismo, a fin de hacerlo más claro y accesible al público no universitario. Lo que interesa destacar aquí es la indicación del propio Hegel en cuanto a que la $F D$ no es un tratado o una ciencia en sí misma y por separado del sistema, sino sólo una parte. Dicho sistema comprende, como se sabe, una lógica, una filosofía de la naturaleza y una filosofía del espíritu. Esta última se divide, a su vez, en espíritu subjetivo, espíritu objetivo y espíritu absoluto. Y la Filosofía del derecho sólo desarrolla lo correspondiente al "espíritu objetivo".

Robert Pippin advierte que toda la "filosofía del espíritu", con sus tres divisiones, contiene lo que puede considerarse la "filosofía práctica" de Hegel, es decir, aquella cuyo objeto es dar cuenta de las acciones para las que pueden exigirse razones o justificaciones a los sujetos que se considera responsables de ellas; es decir, se trata de la filosofía que se ocupa de la libertad. (Cfr. Pippin, 2000: 180) En ese sentido, lo propio de la filosofía del "espíritu objetivo" es dar cuenta de la libertad, pero no considerada ya subjetivamente, sino "en su concepto y realización”.

Con esta orientación, en lo que resta del capítulo revisaremos dos aspectos: el planteamiento de que la libertad es el fundamento del derecho y, segundo, la propuesta hegeliana para desplegar el contenido de la voluntad libre. 


\section{LA LIBERTAD COMO FUNDAMENTO DEL DERECHO.}

En el §4 de la $F D$, Hegel escribe que "el terreno del derecho es lo espiritual, su lugar más preciso y su punto de partida es la voluntad, que es libre, de modo tal que la libertad constituye su sustancia y determinación, y el sistema del derecho es el reino de la libertad realizada..." (p. 77)

Sabiendo que para Hegel lo "espiritual" designa, en términos generales, "toda creación humana", lo dicho en este parágrafo significa que nuestro filósofo persigue un objetivo similar al de Kant: mostrar que el derecho sólo tiene sentido en cuanto es autoimpuesto, superando con ello, en definitiva, las tradiciones del Derecho Natural y del empirismo. Lo que más adelante marca una diferencia entre un autor y otro es que, mientras que Kant considera que el principio de auto-legislación es básicamente algo subjetivo y formal, Hegel cree poder demostrar que la auto-legislación es además un proceso histórico intersubjetivo, sin poner por ello en entredicho el principio de autonomía. En la propuesta de Hegel, el derecho es una expresión del espíritu mismo, la realización objetiva de la libertad.

Aunque Kant haya logrado establecer el principio moral de la autonomía, no parece pensar que el sistema del derecho sea "el reino de la libertad realizada", sino simplemente su condición de posibilidad. Como ya se hizo notar, al vernos afectados por causas naturales que son ajenas, la legislación externa no siempre coincide con los motivos del puro deber. Es por eso que, para Kant, una cosa es la moralidad y otra la legalidad, cuya coincidencia sólo ocurre cuando las leyes de lo externo fungen, además, como fundamento de determinación del actuar. Pero, puesto que nunca dejamos de ser particulares y sensibles, difícilmente lograremos actuar por el puro deber, por la mera forma de una legislación universal. De allí que el derecho termine por expresarse fundamentalmente en dos sentidos muy distintos: como ideal normativo y como coacción, en cuyo caso ya no coincide ni con la legislación vigente, ni con el principio de autonomía. El derecho sólo tiende pues a garantizar una distribución igualitaria de la libertad, mediante la restricción del arbitrio.

En contraste, el §̧ de la FD nos deja ver que, en el caso de Hegel, el derecho está constituido por todas aquellas normas en las que la libertad se realiza objetivamente, incluido el deber moral, pero también por la legislación externa encarnada en las instituciones de la 
vida ética (la familia, la sociedad civil y el estado). En el planteamiento hegeliano, la voluntad libre constituye "lo más preciso y el punto de partida del derecho". Hegel no dirá, entonces, que la moral está por un lado, produciendo leyes puras, y el derecho por el otro, restringiendo el arbitrio. Hegel pretende demostrar que la libertad subjetiva se expresa en un orden objetivo al que se reconoce como una concreción propia.

El fin, en la medida en que es sólo nuestro es para nosotros una carencia, porque libertad y voluntad son para nosotros unidad de lo subjetivo y lo objetivo. El fin debe por lo tanto ponerse como objetivo, con lo que no pasa a otra determinación unilateral, sino a su propia realización. (FD, § 8, Agregado)

En Denis Rosenfield encontramos una expresión acertada de lo que Hegel afirma en el parágrafo 4: "La voluntad es, así, el principio de realización del derecho, el acto gracias al cual las relaciones humanas se dan una nueva forma de existencia." (Rosenfield, 1989: 38) $Y$ es este mismo sentido el que se completa en el §30, donde Hegel afirma que el derecho es algo sagrado en cuanto es la "existencia" o el "ser alli" del "concepto absoluto, de la libertad autoconsciente". De modo que cuando Hegel habla del derecho no sólo se refiere a la legislación externa.

Es verdad que Hegel reconoce el principio de autonomía avanzado por Kant. Él también piensa que "la libertad es una determinación fundamental de la voluntad", y que la "voluntad sin libertad es una palabra vacía". (FD, §4, Agregado) La diferencia radica en que Kant sólo demuestra la posibilidad de una voluntad pura, libre de toda determinación, que sólo ella es buena, buena por el puro "querer cumplir la ley", independientemente de todo objeto... En tanto que Hegel intenta mostrar que las instituciones objetivas de la sociedad política también expresan y realizan la libertad, dotando incluso de sentido a la libertad meramente subjetiva.

Esta es la perspectiva hegeliana que viene a confrontarse con la lógica de la externalidad y con las diversas dicotomías de la filosofía política de Kant. Implica primeramente la crítica de la dicotomía entre dos facultades supuestamente existentes por separado, (la voluntad y el pensamiento), o, para ser precisos, la existencia de dos "usos" de la razón, cada uno con distintos límites y capacidades. Para Hegel, la consideración de que el hombre "piensa" por un lado, y "actúa" por otro, es una representación vacía. Según podemos leer en el Agregado al mismo §4: tanto la voluntad es un modo particular del 
pensamiento, como el pensar es activo. No hay actos humanos sin pensamiento, ni pensamiento sin acción. La voluntad es el pensamiento mismo en tanto impulso a darse una existencia, y el pensamiento no es una facultad meramente contemplativa o formal, sino un modo de acción, toda vez que, cuando conoce, realiza una apropiación de objeto, transformando lo conocido y transformándose a sí mismo.

Para la inteligencia, en cuanto pensante, el objeto y el contenido son siempre algo universal, y ella misma se comporta como algo universal. (...) En la voluntad comienza la finitud propia de la inteligencia, y sólo porque la voluntad se eleva nuevamente al pensamiento y da a sus fines la universalidad inmanente, elimina la diferencia entre forma y contenido y se convierte en voluntad objetiva infinita. Por eso entienden poco del pensar y del querer quienes opinan que el hombre es infinito en la voluntad y limitado en el pensar (o que la razón misma es limitada). (FD, §13, Observación)

Por consecuencia, la propuesta hegeliana también ofrece una crítica de la dicotomía entre la libertad y su realización en el mundo. Para Hegel, la libertad no es un ideal normativo que la filosofía o el sujeto moral autónomo le propongan a la historia humana contingente como un modelo para orientar la acción práctica, sino que, de por sí, la historia no es otra cosa que la voluntad humana que se ha venido realizando, apropiándose del mundo, determinándose, poniendo reglas de intercambio, haciéndose responsable de su acción, estableciendo instituciones políticas... Si el pensamiento y la voluntad son una y la misma cosa, quiere decir que el pensamiento libre ya está actuando desde siempre en la historia contingente, independientemente de si, además, elabora nuevos planteamientos "normativos" cuando las instituciones vigentes ya no le satisfacen. A fin de cuentas, un ideal normativo no surge de la nada, sino que su punto de partida es siempre lo ya existente, aquello que pretende negar o transformar. De allí que, a juicio de Hegel, la filosofía no esté llamada sólo a diseñar un orden ideal que sirva de modelo para la acción sino, fundamentalmente, a concebir lo racional que ya está presente en las configuraciones contingentes por medio de las cuales la voluntad libre se ha venido dando, de por sí, una existencia.

Por eso, haciendo un retorno al polémico Prefacio de la misma Filosofía del Derecho, Hegel nos dice que "De todos modos, la verdad sobre el derecho, la eticidad y el Estado es tan antigua como su conocimiento y exposición en las leyes públicas, la moral pública y la religión..." (Ibíd.: 48) La filosofía sólo consiste pues en concebir lo que es, lo presente, lo real, puesto que ya es racional en sí mismo. A la filosofía no le toca, entonces, proponer un 
más allá vacío y unilateral, arbitrario. El cometido de una filosofía del derecho, para Hegel, no debe ser otro que el de "intentar concebir y exponer al Estado como algo en sí mismo racional." (Ibíd.: 60), algo que no proviene pues del azar.

Lo que Hegel escribe en este pasaje del Prefacio podría sugerir que se renuncia al potencial crítico de la filosofía, como si el fundamento del derecho y del Estado no fuese la voluntad libre, sino lo inmediatamente dado en el estado de cosas, en la tradición. Puesto que cada uno de nosotros nace en medio de otros seres humanos que lo preceden y que ya de por sí se rigen bajo determinadas normas, que viven conforme a unas costumbres establecidas y que ya se orientan por una creencia religiosa específica..., tal parece pues que, para conocer "la verdad" sobre el derecho, la eticidad y el Estado, bastaría con describir esas prácticas aceptadas y nada más. Pero, si así fuera, ¿qué sentido podría tener entonces la filosofía? Si la verdad sobre el Estado ya se conoce y está expuesta ¿qué importancia podría tener el pensar? La filosofía quedaría reducida a un ejercicio inútil, pues lo que ella pretende ofrecer, la verdad de un objeto (en este caso del concepto de la libertad y su realización), ya está desde siempre en las instituciones públicas existentes. ¿Es esto lo que Hegel afirma? Si detenemos nuestra lectura en la primera frase del párrafo, tal parece que así es $y$, en dicho supuesto, estaríamos autorizados a concluir que el autor pone efectivamente a la tradición como el fundamento del derecho, y no a la voluntad libre, como el §4 anuncia.

Sin embargo, apenas avanzamos en ese mismo pasaje del Prefacio, Hegel nos advierte que aquello que se conoce y expone en las leyes y la moral públicas existentes tan sólo es una "verdad parcial", ciertamente correcta, pero al mismo tiempo insuficiente. Porque si suscribimos el irrenunciable principio moderno de la subjetividad, (al que Hegel se refiere aquí con los términos de "espíritu pensante" y "pensamiento libre"), resulta que aquella primera verdad no es más que un "conocimiento inmediato" con el que el espíritu no se conforma de ninguna manera. Lo aprehende, pero sabe que eso no puede ser toda la verdad. Queda pues insatisfecho porque, a los ojos del pensamiento libre, la verdad parcial e inmediata que nos viene dada en las instituciones públicas existentes todavía no goza de legitimidad, es decir, todavía no está justificada ante el pensamiento. El espíritu pensante no acepta ninguna de las versiones de lo simplemente dado: ni lo que se apoya en la autoridad positiva del estado, ni lo que se apoya en el consenso de los hombres, ni en el sentimiento. 
El pensamiento libre, por el contrario, "parte de sí mismo y, justamente por ello, exige saberse unido en lo más íntimo con la verdad." (Ibíd.: 48).

Bajo esta nueva perspectiva que, insisto, se halla unas líneas abajo en el mismo Prefacio, para conocer "la verdad" sobre el derecho, la eticidad y el Estado, no basta con aceptar y describir las prácticas existentes; lo que hace falta es concebir su verdad, comprenderla, comprender lo racional de todas aquellas instituciones del derecho objetivo que al principio sólo se experimentan de manera inmediata, dada.

Queda claro pues que, en la obra de Hegel, la libertad constituye en todo momento la sustancia y la determinación del derecho, su lugar más preciso, su punto de partida. La justificación del derecho no requiere pues una elaboración distinta a la fundamentación de la libertad. No se trata de "deducir" primeramente la libertad y su posibilidad, y luego analizar si ésta es o no una causalidad que opera en el derecho, sino que toda la Filosofía del Derecho trata de la "Idea" del derecho, es decir, de su "concepto y realización", que no pueden ser cosas distintas. La libertad es el principio tanto del derecho abstracto, como de la moralidad y de la eticidad; o, dicho a la inversa, el derecho abstracto, la moralidad y la eticidad no son sino la existencia que la voluntad libre se da a sí misma, que no difiere de su idea como si fuese algo externo. En el caso de Hegel no existe pues ningún motivo para poner a la libertad y al derecho como cosas aisladas...; algo que sí ocurre en el argumento de Kant, según lo señala el propio Hegel:

La determinación kantiana, admitida generalmente, cuyo momento central es "la limitación de mi libertad o arbitrio de modo tal que pueda coexistir con el arbitrio de todos de acuerdo con una ley universal", contiene sólo una determinación negativa, la de la limitación. (...) ....el fundamento esencial y primero no es la voluntad en cuanto racional y existente en y por sí, sino en cuanto voluntad del individuo según su propio arbitrio... (...) Una vez aceptado este principio, lo racional sólo puede aparecer como una limitación para esa libertad, es decir, no como racional inmanente, sino sólo como universalidad abstracta, exterior. (FD, §29)

El principio de auto-legislación avanzado por Kant es irrenunciable, un punto de no retorno para la filosofía política moderna. El problema es que, aun cuando llega a reconocer que el derecho debe ser auto-impuesto, la propuesta kantiana no supera el momento meramente formal y subjetivo de la moral. El énfasis de Kant está en que el sujeto es autónomo, pero lo es formalmente, como si el derecho no fuese realmente una determinación suya. De este modo, cualquier expresión objetiva le resulta algo ajeno, como 
si "el bien" del sujeto fuese incompatible con el ámbito objetivo. Desde la perspectiva del sujeto moral, "el bien" es algo que siempre se posterga, algo que nunca es ya real.

\section{EL CONTENIDO DE LA VOLUNTAD.}

Hegel explora el contenido de la voluntad libre en los parágrafos 5,6 y 7 de la $F D$, mostrando que es así como la voluntad habría de desplegarse cuando se la concibe según su propia necesidad. El contenido de la voluntad se demuestra en su despliegue dialéctico y no como un "atributo" que podamos deducir de algún otro fenómeno, de la conciencia de alguna ley moral dada, o como una capacidad natural en el ser humano. Lo que tenemos a continuación es entonces el modo más apropiado para ocuparse filosóficamente de la libertad, de acuerdo con Hegel.

En apego a las exigencias de la Lógica, Hegel no inicia anteponiendo algún principio en torno al contenido de la voluntad, comienza por lo más indeterminado de la voluntad misma; en tanto que la investigación no avanza sino hacia donde la conduce el concepto de la propia voluntad. Como fruto de este procedimiento, el contenido de la voluntad se despliega en tres momentos o dimensiones, pero queda claro que no se trata de momentos añadidos o superpuestos, sino el desarrollo de la voluntad misma que sale paulatinamente de su unilateralidad.

\section{a. El momento de la pura indeterminación.}

Hegel señala primeramente que la conciencia de la voluntad comienza con la pura indeterminación, con la reflexión del yo en sí mismo, con la disolución de todo límite, de todo contenido determinado. En este acto, la voluntad se aparta de cualquier contenido que pudiera representar un límite a las posibilidades infinitas del ser práctico. Hegel define a este comienzo de la voluntad como el momento de la "libertad negativa o del entendimiento". (Cfr. §5) Cuando actúa una voluntad que se sabe así indeterminada, su acción se traduce exclusivamente en la destrucción de todo orden social existente, en el rechazo de toda realidad positiva, de todo compromiso particular. La voluntad lo destruye y lo aniquila todo. 
Es un momento de pura abstracción, pero, por cierto, es también una capacidad de la que sólo goza el ser humano:

El hombre es el puro pensamiento de sí mismo y sólo en cuanto pensante es la fuerza de darse universalidad, es decir, de borrar toda particularidad, toda determinación. (FD, §5, Agregado)

En el Agregado al $§ 5$ se anotan algunas expresiones históricas de este momento de pura indeterminación: en la religión hindú, donde el practicante se esfuerza por mantenerse en el espacio vacío de la interioridad; así como en la etapa del terror de la Revolución Francesa, ese momento en que el pueblo destruyó las instituciones que recientemente habían sido creadas por él mismo. Instalada en el elemento de su pura indeterminación, la voluntad rechaza pues cualquier postura y no quiere verse reflejada en lo real de modo alguno, no existe ni una sola concreción que le satisfaga. Es la pura posibilidad infinita.

Con todo, el acto de indeterminación de la voluntad libre es tan importante que, como observan algunos comentaristas, en él descansa la posibilidad misma de que el yo llegue a percibirse como un ser práctico, de que logre percibirse como agente. El yo debe ser capaz de desprenderse de lo positivo, de negarlo todo, de abandonar cualquier limitación, abstraerse de toda situación particular; de lo contrario, jamás llegará a saberse capaz de actuar, como fuente de cambio para llegar a elaborar nuevas posibilidades, para llegar a producir lo que todavía no es. Gracias a este momento de abstracción y de pura indeterminación, entonces, el yo se halla inmediatamente presente ante sí mismo y se sabe con el poder de hacer e iniciar un curso de acción en un sentido distinto al existente, a lo dado. Esto demuestra también que el ser humano es capaz de negar y sobreponerse a las pasiones, deseos e intereses propios de la causalidad natural, porque sería capaz de renunciar incluso a su propia vida. En este momento de pura indeterminación el sujeto percibe que todo puede ser modificado y que él es precisamente la fuente de toda una gama de posibilidades para generar cambios en el mundo: "es sólo porque el sujeto es capaz de abstraerse de toda situación específica que puede concebirse como capaz de generar lo que todavía no es." (Cfr. Houlgate, 1995: 865)

De acuerdo con el mismo Houlgate, este momento de la pura indeterminación no termina aquí, sino que permanece incluso cuando el yo se decide en un sentido específico. Es decir, si la capacidad de abstracción es indispensable para reconocernos como seres 
prácticos, esta debe estar presente en todo momento, incluso cuando optamos en un sentido particular. "...uno debe preservar el sentido de que, aunque se haya resuelto por esta posibilidad y no otra, uno no está limitado por ninguna de ellas y siempre puede resolverse por cualquier otra." (Ibíd.: 866)

Con este momento de la pura indeterminación resurge pues una notable diferencia entre Hegel y Kant porque, para Kant, la conciencia de la libertad es algo secundario, una "capacidad de hacer" cuya conciencia sólo se debe a que, primeramente, hemos tenido conciencia de algún deber que Kant considera un "hecho dado".

\section{b. El momento de la particularización.}

De conformidad con Hegel, sin embargo, la voluntad no se queda fija en este momento inicial, abstracto e indeterminado, sino que quiere salir de sí misma, quiere manifestarse, quiere poner una diferencia. De tal manera que la voluntad niega aquel primer elemento y de ese modo transita de la pura indeterminación indiferenciada a la diferenciación, al poner una determinación, un contenido y un objeto. En este segundo momento el yo no sólo expresa que "quiere", sino que además "quiere algo". (Cfr. FD, §6) Esto conlleva que la voluntad se pone un límite, el yo entra en la existencia. Pero este elemento también es negación, en tanto que niega y elimina aquella primera indeterminación.

Con este segundo momento Hegel quiere advertirnos que la indeterminación primera no es del todo indeterminada, sino que su determinación consiste precisamente en ser unilateral y abstracta; esa es precisamente su carencia, su finitud. "Una voluntad que (...) sólo quiere lo universal abstracto, [en realidad] no quiere nada y no es por tanto una voluntad. (...), para ser tal, la voluntad debe en general limitarse." (FD, §6, Agregado)

La relevancia de este segundo momento radica pues en que el yo se particulariza, sale de aquella universalidad abstracta e introduce la diferencia. $Y$ es que la identidad de que goza el yo en el primer momento es tan indeterminada como universal, es decir, le pertenece al mismo tiempo a cualquier otra voluntad igualmente indeterminada. Allí no existe especificidad, no hay una diferencia que permita distinguir a una voluntad indeterminada de otra. De acuerdo con este momento de particularización, entonces, el yo debe elegir una 
opción particular y actuar en una situación específica para llegar a ser libre. Porque, si acaso decide quedarse en el momento de la pura indeterminación, con ello estaría renunciando a una serie de rasgos específicos (naturales, históricos, opciones hechas...) que permiten distinguir a una voluntad, con respecto a otras que también son indeterminadas. (Cfr. Houlgate, 1995: 867)

Para expresar de otro modo el rasgo distintivo de este segundo momento en que la voluntad se determina, conviene recurrir a las nociones lógicas de "negatividad" y "mediación". En su indeterminación, la voluntad carece de mediaciones, puesto que lo rechaza y lo niega todo. En el momento de la diferenciación, por su parte, lo que ocurre es que aquella misma negatividad se mediatiza en el mundo. Apoyados en Rosenfield notamos que:

“... la voluntad se sitúa como igual a sí misma en la exterioridad de su ser otro... (...) Esto significa que el "Yo", en la abstracción de su infinitud individual, acepta someterse a la finitud de las cosas, a la diferencia, a la desigualdad. La voluntad anuncia aquí cómo empieza a aventurarse en la creación de un mundo propio, corriendo el riesgo en la certeza de que la libertad no puede ser engendrada sino cuando se enfrenta a sus limitaciones... (Rosenfield, 1989: 42-43)

Y cabe hacer otro apunte sobre las variaciones entre Hegel y Kant. Según este último, el sujeto debe elegir siempre actuar por deber, por el puro "querer cumplir la ley". Hegel diría, sin embargo, que este formalismo deja al sujeto en el momento de la indeterminación, y una voluntad que no se determina, que no elije "algo" en particular, no es realmente una voluntad. Una voluntad que sólo quiere la forma de la legislación universal es una voluntad trunca en su proceso de autoproducción como voluntad libre: "Una voluntad que no decide nada no es una voluntad real. (...) Sólo por medio de la decisión entra el hombre en la realidad, por muy amargo que esto pueda parecerle...” (FD, §13, Observación)

\section{c. El momento de la unidad.}

Pero la voluntad libre tampoco detiene su proceso de determinación en el momento de la mera particularidad, sino que avanza hacia la unidad de los dos momentos precedentes y esto constituye el momento de la plena autodeterminación del yo, porque el sujeto se ha puesto un límite, pero se lo ha puesto él mismo. De modo que, aun cuando entra en la 
existencia y se pone un límite, permanece en su identidad indeterminada consigo. Hegel piensa que la voluntad solamente es libre porque se niega a sí misma, pero retorna a sí. Significa pues que, no obstante que se particulariza, que se arriesga en lo finito, permanece como sí mismo, como universal. El comentario de Houlgate era pues correcto. Este tercer elemento que reúne a los dos anteriores significa que aun cuando el yo se determina, dicha determinación es suya, es una posibilidad puesta por él mismo y a la que, por ende, no permanece atado.

Hegel piensa que el concepto y la sustancialidad de la libertad sólo radican en esta unidad internamente diferenciada, en este tercer momento que niega, supera y contiene a la vez los dos primeros momentos de la universalidad y de la particularidad. (Cfr. §7) Quiere decir pues que la voluntad es libre en cuanto: 1) es capaz de abstraerse de todo; 2) sale de sí, se determina, se pone un límite, y 3) retorna a sí. Este es el contenido de la voluntad libre de acuerdo con Hegel. En un plano pragmático, significa que el ser humano sólo es libre en un mundo al que reconoce como propio, como obra suya. Según esto, un sujeto debe comprometerse e identificarse con una opción, debe aceptar una situación como resultado del esfuerzo humano. En vez de huir a los compromisos, debe aceptar una situación de vida. Aunque se reconoce como la fuente de nuevas posibilidades, la libertad tiene un componente real, efectivo. La autoconciencia se sabe universal y particular a la vez, pero lo realmente verdadero es que la voluntad, en tanto particular, se sabe coincidente con lo universal: “... sólo es voluntad como esa actividad que se media en sí misma y como retorno a sí." (Ibíd.: Observación)

Este es el concepto concreto de la libertad, mientras que los dos momentos precedentes se han manifestado enteramente abstractos y unilaterales. (Ibíd.: Agregado)

Una concepción concreta de la voluntad libre se logra entonces cuando, por vía de la negación, se transita de la pura "indeterminación" universal a la "particularidad" y, por vía de la negación de la negación, a la unidad de ambos momentos previos en la "singularidad", en un proceso dialéctico que no se detiene.

Es por eso que a Hegel le parece insuficiente la convicción kantiana de que la libertad sólo es un atributo del arbitrio, o bien, el ideal de elegir aquellos motivos de acción relativos al puro querer cumplir la ley. Para Hegel, además de la capacidad de estar consigo en su 
universalidad, la libertad es también el arriesgarse y el ponerse límites en este mundo contingente hecho por nosotros mismos. La voluntad libre es pura posibilidad, pero no sólo, también es una posibilidad determinada; más aún, la voluntad libre es posibilidad determinada que, sin embargo, no por ello pierde su autonomía. La voluntad libre es práctica, abandona su indeterminación, se determina, pero, sobre todo, se auto-determina. La voluntad es universal, pero también es algo real y objetivo. En pocas palabras, “...la voluntad verdadera consiste en que aquello que se quiere, su contenido, sea idéntico a ella, es decir, que la libertad quiera la libertad." (FD, §21) Adriaan Peperzak resume al respecto que:

...el ser humano libre experimenta la libertad por medio de su participación en un mundo humano y creado por él mismo de derecho, vida familiar, economía y política. Sólo aquí en el mundo de las relaciones sociales, costumbres e instituciones, puede la voluntad, que quiere su propia libertad, encontrar un contenido adecuado para su autonomía. (Peperzak, 1989: 112-113)

Lo relevante no es, entonces, la estructura tridimensional del concepto de voluntad, sino la insistencia hegeliana de que la verdad jamás radica en alguno de sus momentos, sino en su unidad internamente diferenciada. Tomadas por separado, cada una de aquellas dimensiones carece de sentido y eso es lo que le habría sucedido al contractualismo, que se queda con la idea de que la libertad es algo meramente natural; pero también a Kant, que sólo piensa en la libertad como autonomía formal subjetiva. En la lógica hegeliana, en cambio, no nos vemos obligados a elegir y argumentar cuál de las versiones anteriores de la libertad es la más atinada porque, sencillamente, es la voluntad misma la que exige abandonar las posturas abstractas, en busca de nuevas determinaciones.

Los dos primeros momentos del concepto de libertad se ven entonces suprimidos en su unilateralidad, en su abstracción y en su carácter inmediato, pero están presentes en el tercer momento de la autodeterminación. Por otro lado, el modo en que el contractualismo y el idealismo trascendental han concebido la libertad son, de cualquier manera, momentos por los que el espíritu ha transitado y transita en su proceso de autoconciencia de la libertad, hacia formas cada vez más plenas.

He aquí el modo en que hay que concebir filosóficamente el contenido de la voluntad, de acuerdo con Hegel. Este es el modo en que la voluntad se autoproduce y toma conciencia de sí misma en cuanto libre. El procedimiento de Hegel, lejos de rehuir la contradicción, se 
apoya precisamente en ella y eso es lo que le permite relacionar dialécticamente aquellos términos que en planteamientos precedentes sólo se habían tomado como dato básico e ineludible. 


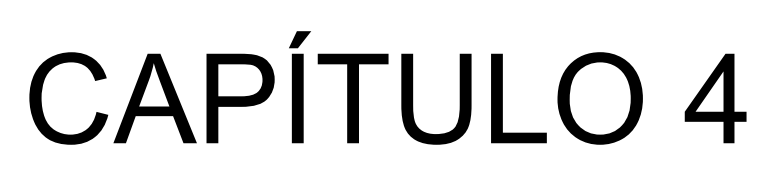

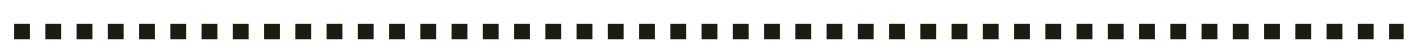

\section{LA LIBERTAD \\ EN SU EXISTENCIA}


El divorcio entre libertad e institución, si fuese durable, marcaría la más grande negación de la idea de razón práctica.

Ricoeur. Hermenéutica y acción.

En la sección precedente abordamos el modo en que Hegel propone concebir filosóficamente el contenido de la libertad. Por lo que allí pudimos observar, el procedimiento que sigue nuestro autor le permite desplegar teóricamente el concepto de voluntad libre sin tener que recurrir a una separación dicotómica entre un mundo fenoménico y uno de lo "en sí". El concepto de libertad no adquiere su razón de ser a partir de algún principio externo a ella misma, sino atendiendo a la necesidad interna del concepto. Por esto mismo, la libertad no debe reducirse ni a su aspecto universal, ni a la mera facultad del arbitrio para elegir entre distintos motivos de acción. En la propuesta hegeliana, la concepción de la voluntad libre comienza con un acto de pura indeterminación en donde el yo se abstrae y lo niega todo, está consigo mismo y se sabe un sujeto de posibilidades infinitas...; pero no llega a ser una voluntad plenamente libre sino cuando niega este primer momento y transita hacia otras determinaciones igualmente indispensables: la de particularizase en un sentido específico de acción y la de reconocer que este modo limitado de actuar es suyo, es decir, cuando se sabe una voluntad concretamente auto-determinada.

Hemos hecho notar también que, bajo este modo peculiar de concebir la libertad, no es necesario plantear una relación de externalidad entre una moral pura y una antropología pragmática, ni entre una legislación moral interna y otra legislación jurídica externa... Porque, insistimos, el proceso de autoproducción de la libertad no concluye con el mero estar consigo de la voluntad en su universalidad, sino que debe reconocerse como libre en lo otro de sí, en un mundo objetivo que se da a sí misma. Es por eso que, con Hegel, todo el sistema del derecho, (que comprende la legislación jurídica, pero también el deber moral y las nomas de las instituciones éticas), es la realización de la libertad misma y no sólo las condiciones de posibilidad para su realización. Si bien se trata de expresiones de la voluntad en el mundo contingente de la experiencia, no por ello carecen de su aspecto universal. La argumentación hegeliana nos permite pues reconocer que el proceso racional de autolegislación es efectivo, real e histórico, y no sólo un modelo que se mantiene a distancia de lo contingente, influyendo sobre él. En suma, el modo en que Hegel propone concebir la libertad nos dice que la realización de la voluntad en el mundo es un aspecto tan indispensable como la demostración de su mera posibilidad; esto es lo que puede concluirse 
cuando se atiende no sólo el contenido manifiesto, sino también el modo peculiar que tiene Hegel de conceptualizar.

Sin embargo, hasta ahora sólo hemos reconstruido el concepto de voluntad libre, todavía no su existencia. Los primeros parágrafos de la Filosofía del Derecho sólo se refieren al contenido de la voluntad libre, a su fundamentación, pero no abordan aquello que Hegel llama la "determinación y existencia" de la libertad; es decir, todavía no consideran el ser-allí de la libertad, el modo en que la voluntad actúa en el mundo. El paso a este ámbito se registra en los parágrafos del 29 al 33 de la FD. En la Observación al §30, Hegel escribe que

Cada estadio del desarrollo de la idea de libertad tiene su propio derecho, pues es la existencia de la libertad en una de sus determinaciones peculiares. (...) La moralidad, la eticidad, el interés del estado, constituyen cada una un derecho peculiar, porque cada una de esas figuras es una determinación y existencia de la libertad. (p. 92)

Como se indica, las determinaciones, formas de existencia o configuraciones de la libertad que Hegel explora en la FD son: el derecho abstracto o la libertad de la persona, la moralidad o el derecho de la voluntad subjetiva, y la eticidad o la autodeterminación concreta. $Y$ el despliegue de estas configuraciones de la libertad es el segundo momento en donde se percibe el apego de la Filosofía del Derecho a las exigencias que la Ciencia de la Lógica le interpone a toda ciencia filosófica. Aquí también, bajo un procedimiento que nuestro autor considera como el más adecuado para una ciencia filosófica, la investigación renuncia a toda reflexión preliminar, comienza por lo más inmediato y, finalmente, avanzar exclusivamente por donde la conduce la propia voluntad que se realiza. Se comienza por el "derecho abstracto" y no se transita a una nueva configuración sino cuando esta primera realización se contradice a sí misma. Es así como nos vamos percatando de que la libertad de la persona y la libertad del sujeto moral son configuraciones necesarias, aunque también insuficientes, de una plena realización de la libertad, por lo que requieran de la eticidad. Lo que leemos en el $\$ 30$ señala justamente que, aún en su inmediatez, cada una de estas formas de existencia constituye una expresión auténtica de la ldea de libertad, cada una es el ser-allí de la Idea de libertad. Lo que se intenta destacar en este apartado es, entonces, por qué cada una de estas configuraciones entra en contradicción, haciendo preciso superarlas y tomarlas en su relación indisoluble, en lugar de afianzar alguna de ellas en su aislamiento. 
Hacia la tercera sección de la $F D$ Hegel plantea que la eticidad es un ámbito en el que se subsumen y adquieren sentido el derecho abstracto y la moralidad; plantea también que la eticidad es la identidad concreta del bien con la voluntad subjetiva..., pero tales afirmaciones pueden parecer arbitrarias, a menos que se tenga en cuenta el procedimiento que adopta el autor, según el cual, las determinaciones mismas transitan de una a otra. Por el contrario:

...el abstraer del entendimiento consiste precisamente en asirse a viva fuerza a una determinidad y en esforzarse en oscurecer y alejar la conciencia de la otra [determinidad] que reside allí... (Enc., §89, Nota)

La eticidad no es, entonces, una propuesta arbitraria, sino resultado del proceso de determinación de la voluntad misma. Esto significa también que el derecho abstracto y la moralidad no son configuraciones erróneas o equivocadas de la libertad. No se trata de determinaciones de la libertad que simplemente deban dejarse atrás, como si el devenir hacia la eticidad describiese un progreso lineal en el tiempo. En todo caso, la filosofía política hegeliana quiere dar cuenta del proceso conceptual que nos conduce, de modo necesario, hasta la posición de la libertad como eticidad; pero dicho proceso puede comprenderse como un "ir al fundamento" y no como un progreso lineal en el tiempo; se trata de ir a lo firme, a lo mediado, a lo más concreto, a lo menos abstracto e inmediato...

Así podemos entender que, si Hegel comienza la Filosofía del derecho con el "derecho abstracto", no es porque piense que dicha configuración habría sido la primera que tuvo lugar en la historia. De semejante configuración puede decirse, en cambio, que es la más abstracta, la más inmediata, la más indeterminada de las formas de libertad de que se tiene conciencia en un momento dado. $Y$ el tránsito de una configuración de la libertad a otra responde, más bien, a la exigencia de "ir al fundamento", de pasar de lo inesencial a lo esencial, de lo que es abstracto a lo que se media internamente.

Bajo esta comprensión, nuestro autor considera pues que el tomar al objeto como dialécticamente constituido es el procedimiento que mejor se ajusta al quehacer de la filosofía, ya que no admite nada como "dado" y no acepta principios externos como explicación posible del objeto en cuestión, aquí la voluntad libre en su existencia. En refuerzo de una de las exigencias para toda ciencia filosófica expuestas en la Lógica, en el Prólogo a la Fenomenología Hegel nos dice que “...un llamado fundamento o principio de la 
filosofía, aun siendo verdadero, es ya falso en cuanto es solamente fundamento o principio..." (p. 18) Sabido es que para Hegel, al igual que para la filosofía moderna en general, la razón es autosuficiente en lo que al conocer y al actuar concierne. Luego de Descartes y Hobbes, la razón es el único principio aceptable en todos los ámbitos. El matiz en el caso de Hegel es que, además, plantea que la razón está movida internamente por la negatividad, por la contradicción. La razón no es entonces una estructura formal fija que opere bajo algún principio dado.

Llamo dialéctica al principio motor del concepto, que disuelve pero también produce las particularidades de lo universal. (...) La más elevada dialéctica del concepto consiste en no considerar la determinación meramente como límite y opuesto, sino en producir a partir de ella el contenido positivo y el resultado, único procedimiento mediante el cual la dialéctica es desarrollo y progreso inmanente. (FD, §31, Observación)

Esto nos da una idea de la labor que Hegel emprende en la Filosofía del derecho. La voluntad libre se determina y se configura de cierto modo, se da una cierta realidad en el mundo y esto puede parecernos un límite. Pero, movida por la negatividad o la negación de su propia delimitación, la voluntad libre continúa superando la inmediatez o la unilateralidad en la que suele fijarse, poniendo con ello otras formas de realización de la misma voluntad. Hegel toma a su cargo la tarea de conceptuar lo que hay de necesario, de racional, lo que hay de permanente en todas aquellas formas contingentes e históricas en que se realiza la voluntad, ya sean estas obligaciones jurídicas, deberes morales o códigos éticos. Por eso escribe que, para aprehender verdaderamente la libertad, es preciso conocerla "en su concepto y en la existencia que adopta su concepto." (FD, § 1)

Hegel insiste también en que la filosofía no debe dividir desde fuera o clasificar cierta materia ya existente, utilizando algún principio aceptado, sino atender al "diferenciarse inmanente del concepto mismo." ( $F D$, §33) Por eso, lo que ahora nos interesa revisar es exactamente en qué consisten, según el autor, tanto la importancia como la insuficiencia del derecho abstracto y la moralidad, así como la necesidad de transitar de una configuración de la libertad a otra, hasta llegar a la eticidad, que las contiene y les da sentido.

En el presente capítulo revisaremos el despliegue de la voluntad libre en su existencia, pero debe tenerse en cuenta que, en cualquiera de sus determinaciones, el concepto de voluntad libre que subyace es uno y el mismo: 
En cuanto la voluntad tiene como contenido, objeto y fin a la universalidad, a sí misma en su carácter de forma infinita, no sólo es voluntad libre en sí sino también por sí, es verdadera idea. (...) El principio del derecho, de la moralidad y de toda eticidad está constituido precisamente por esta autoconciencia que se capta como esencia por medio del pensamiento, toda vez que así se desprende de lo contingente. (FD, §21)

Ya hemos hecho notar que, bajo esta perspectiva, Hegel ejerce una crítica de los sistemas filosóficos de Rousseau y de Kant, para quienes las determinaciones objetivas de la voluntad libre, como son la legislación jurídica o la vida ética, parecen encarnar una fuerza meramente limitante e impuesta desde fuera, que amenaza la universalidad del sujeto particular. En tanto que, para Hegel, la voluntad libre permanece ella misma, en su universalidad, incluso cuando se manifiesta en la existencia bajo la forma objetiva del derecho, de la moral y/o las instituciones de la vida ética, particularmente el Estado. Hay dos comentaristas de Hegel que destacan este aspecto; uno de ellos anota que "La universalidad no es más que universalidad puesta, despliegue en lo otro que es, en verdad, interior en ella misma." (Rosenfield, 1989: 25). El otro comenta que, "para realizar su concepto en el lado objetivo exterior, la libertad quiere ser un mundo determinado por ella..." (Pawlik, 2005: 26).

Al avanzar en las diversas determinaciones que adopta la voluntad libre, entonces, habrá que tener presente esta idea: es la misma voluntad la que se da una existencia, la que se determina o, mejor aún, la que se auto-determina. En efecto, otro modo de comprender el trabajo de Hegel, en su conjunto, es mirarlo como un esfuerzo por alcanzar aquella forma de libertad más concreta y auto-determinada, esto es, la menos determinada por algún factor extraño, cualidad que sólo cumple la eticidad.

\section{EL DERECHO ABSTRACTO O LA LIBERTAD DE LA PERSONA.}

La primera configuración de la libertad se define, en términos generales, por su abstracción, por su inmediatez, por el comportamiento meramente negativo de la persona frente a un mundo externo dado, así como por su carácter individual. 
El mundo frente al que quiere actuar el individuo es un mundo dado, hecho. Cuando éste reconoce en sí su derecho, su libertad, percibe que el mundo simplemente está allí para ser negado, para actuar sobre él, para apropiárselo. El individuo no advierte, por lo pronto, que se trata de un mundo ya estructurado por otras voluntades que se han venido dando ciertos medios de realización.

La libertad de la persona se define pues por su abstracción e inmediatez; el derecho del individuo carece de contradicción, carece de cualquier tipo de mediación. En primera instancia, la persona sólo se percibe a sí misma, es decir, considera que el derecho es únicamente suyo, su derecho individual. Cada uno considera que tiene un derecho ilimitado. Visto en perspectiva, puede notarse que la conciencia de alguna oposición entre universalidad e individualidad está del todo ausente en esta primera forma de existencia de la libertad, oposición que sí encontramos en la moralidad. Y, no habiendo oposición, tampoco es posible hallar aquí algún tipo de unidad internamente diferenciada, a la que sólo se aspira en el momento de la eticidad. La libertad abstracta consiste, por tanto, en un comportamiento de mera negación de lo real y es a esto a lo que Hegel denomina la "libertad de la persona":

La personalidad sólo comienza cuando el sujeto tiene conciencia de sí no meramente como algo concreto, determinado de alguna manera, sino como yo abstracto, en el cual toda limitación y validez concreta es negada y carece de valor. En la personalidad está, por lo tanto, el saber de sí como objeto, pero como objeto que ha sido elevado por el pensamiento a la simple infinitud y es por ello puramente idéntico consigo mismo. (FD §35, Observación)

La relevancia de esta primera forma de la libertad radica en que aquí la persona deja de ser vista como un objeto más y deja de ser considerada un ser natural. El individuo que se sabe libre sólo puede ser objeto de sí mismo, sólo él dispone de sí mismo. Esta primera forma de existencia de la libertad implica pues la superación del ser natural. Aunque se trate de un ser finito (con las condiciones corporales, psicológicas, socio-históricas y demás que lo caracterizan), la persona se sabe al mismo tiempo depositaria de lo infinito, de una amplia gama de posibilidades.

En este punto resulta conveniente indicar, una vez más, la diferencia entre el punto de partida del pensamiento político de Hegel y el de los diversos contractualismos. Para éstos últimos, el punto de partida es la consideración del individuo como un ser natural, 
determinado por las inclinaciones, los deseos y las pasiones naturales; o bien, libre por naturaleza. En tanto que, para Hegel, el punto de partida es la consideración del individuo como capaz de abstracción, capaz de reconocerse como un ser indeterminado. Más que pensar en el dato de un ser natural, Hegel quiere demostrar el modo en que la voluntad supera las determinaciones naturales, en un proceso tendiente hacia determinaciones cada vez más libres. En función de esta diferencia, la tradición del contractualismo ha tenido que pensar en la libertad como una "facultad" que se añade o se impone al ser humano, o bien, como una posibilidad que ya existe en él de modo natural y que hay que controlar si queremos coordinar la convivencia social. Hegel, por su lado, comienza con la conciencia de la indeterminación del propio sujeto, de tal manera que la voluntad es una capacidad que se auto-produce y se realiza inmanentemente en sus distintas configuraciones. Para las distintas versiones del contractualismo, lo natural del ser humano es un dato, un hecho; para Hegel, la libertad comienza con la concepción del "yo" como un ser indeterminado, en un acto de abstracción. Luego se verá que esta forma de libertad, en su abstracción e inmediatez, sólo es el "comienzo", pero Hegel muestra que la existencia de la libertad inicia con esta primera configuración que, aunque abstracta, individual e inmediata, afirma el derecho de la persona y contiene la posibilidad de otras formas de libertad mucho más firmes. Esta forma de libertad revelará, en su momento, la fijeza, la unilateralidad y el aislamiento, volviendo forzoso el poner otra forma de libertad más concreta.

Dado su carácter inicial, esta forma de libertad no puede expresarse sino en reglas formales y prohibitivas tales como "sé una persona y respeta a los demás como persona..." (FD, § 36), y "no lesiones la personalidad y lo que se sigue de ella." (FD, § 38) Aun así, el yo que se sabe libre busca darse una existencia conforme a su derecho y es exactamente bajo este afán que la voluntad se actualiza y ejerce su derecho en las figuras de la propiedad, el contrato y la injusticia, que veremos a continuación.

Debido al enfoque de nuestro trabajo, no nos vamos a detener con detalle en cada una de las expresiones del derecho abstracto, pero conviene revisarlas por el tratamiento lógico que Hegel hace de ellas. 


\section{a. La propiedad.}

De acuerdo con nuestro autor, el derecho a la propiedad es un ejercicio indispensable de la persona, toda vez que así se hace de una esfera exterior en la que manifiesta su saberse libre. Para ser libre, la persona debe tomar posesión de las cosas que le son externas, debe concretar su interioridad en la exterioridad. En pocas palabras, la voluntad adquiere existencia primeramente por medio de la propiedad.

Hegel puntualiza al respecto que lo más importante de la propiedad no radica pues en la satisfacción de necesidades, sino justamente en la exigencia que tiene la voluntad de ejercer su derecho. Y precisa también que la propiedad tiene su límite en la personalidad misma, ya que una persona no debe apoderarse de otra, porque la estaría tomando como una cosa, negando su derecho elemental a ser persona.

Aquí es pertinente subrayar la reflexión que hace Hegel en la Observación al §44 con motivo del derecho de apropiación de la persona. El derecho de propiedad nos enseña que las cosas carecen de valor por sí mismas y que sólo adquieren sentido en la medida que se lo da la voluntad. Con base en ello, nuestro autor retoma la crítica de la supuesta relación de externalidad entre la voluntad y las cosas. Cuando la voluntad se apropia del mundo demuestra que las cosas no son independientes en y por sí, sino que dependen enteramente de la voluntad. De cara al postulado kantiano de un ámbito de lo "en sí" que nos evade, Hegel advierte que este simple comportamiento pragmático de la voluntad humana es una prueba de que no hay nada de las cosas que nos resulte ajeno. Las cosas del mundo son determinadas por la voluntad humana en tanto que tomamos posesión completa de ellas: en lo que "son" realmente y en lo que "aparecen".

Con esto vuelve a ponerse en juego la convicción hegeliana de que la voluntad y el pensamiento no pueden ser facultades o usos de la razón que actúen por separado. Así como el pensamiento "universaliza" y hace suyo lo finito que conoce; así la voluntad, cuando se determina en un acto de apropiación, se "particulariza". Resulta pues difícil pensar que la voluntad y el pensamiento actúan como dos facultades o usos distintos en cualquiera de estos movimientos. Y resulta difícil aceptar, asimismo, que la voluntad o el pensamiento sólo se relaciona con la expresión fenoménica de las cosas en sí mismas. 
Pero quizá el aspecto más relevante de la figura de la propiedad es la "toma de posesión" del propio cuerpo. La persona debe hacer que su naturaleza empírica se determine libremente; la voluntad debe tomarse como su propio objeto. Hegel reitera con esto que la libertad no es entonces una capacidad que sólo se ejerce de modo espiritual, sino que opera en la existencia empírica de la persona, en su propio cuerpo:

\begin{abstract}
Según su existencia inmediata, el hombre es en sí mismo algo natural, exterior a su concepto. Sólo por medio del cultivo de su propio cuerpo y espíritu, esencialmente cuando su autoconciencia se aprehende como libre, se toma él en posesión y deviene propiedad de sí mismo y frente a los otros. Este tomar en posesión es, a la inversa, el poner en la realidad lo que él es según su concepto... (FD, §57)
\end{abstract}

Lo anterior implica que ninguna justificación de la esclavitud es realmente admisible, porque todas ellas tomarían al ser humano como un ser meramente natural, lo que contradice su concepto, su ser libre, el ser dueño de sí. Sin duda que la persona puede ser esclavizada de facto, pero se trata de una condición que no podría defenderse bajo ninguna perspectiva. La posibilidad de la esclavización, por cierto, le permite a Hegel adelantar que la existencia de la libertad como derecho abstracto, lejos de estar en oposición con el derecho del Estado, en verdad lo presupone y lo requiere; de lo contrario, el derecho de la persona podría llegar a verse reducido a un deber que los individuos podrían cumplir o dejar de cumplir, según su capricho: “...únicamente con el conocimiento de que la idea de la libertad es sólo verdadera como estado se asegura que el espíritu objetivo, el contenido del derecho, no sea nuevamente reducido a su concepto subjetivo..." (Ibíd., Observación)

\title{
b. El contrato.
}

En el afán por ejercer su derecho, la voluntad requiere manifestarse, además, en la figura del contrato. Ésta es la segunda de sus expresiones, que se sigue necesariamente de la propiedad. La importancia del contrato se halla en que aquí la voluntad individual ya no sólo se realiza unidireccionalmente con respecto a una cosa, al apropiarse de ella, sino que ahora tenemos la relación entre dos propietarios. A fin de cuentas, nos recuerda Hegel, lo esencial de toda forma de "existencia" es que "existe para otro". (Cfr. Enciclopedia, §91) Quiere esto decir que la existencia que la voluntad se da a sí misma en la propiedad carece de sentido, a menos que otra voluntad la reconozca. A juicio de Hegel, la figura del contrato se presenta incluso como el fin y el sentido de la propiedad; es decir, la persona no busca 
solamente apropiarse de las cosas del mundo, sino que quiere que los otros la reconozcan como una persona libre, como propietario:

Esta relación de la voluntad con la voluntad es el campo propio y verdadero en el que la libertad tiene existencia. Esta mediación por la que se tiene una propiedad no sólo mediante una cosa y mi voluntad subjetiva, sino al mismo tiempo mediante otra voluntad y por lo tanto en una voluntad común, constituye la esfera del contrato. (FD, $\S 71)$

En la medida que el contrato es un esfuerzo de la voluntad por obtener el reconocimiento de los otros, en esa misma medida representa un primer obstáculo para el derecho abstracto que inicialmente se tenía por ilimitado. Puesto que en el contrato intervienen dos voluntades, ambas tienen algo que ceder: ambas tienen que otorgarle al otro su reconocimiento y deben comprometerse a respetar un acuerdo. El problema de la abstracción persiste, no obstante, en la medida que las voluntades involucradas continúan comportándose como "voluntades aisladas" e "independientes", que se aferran pues a su individualidad, y que se niegan a identificarse la una con la otra.

Aquí conviene recordar que los alcances del contrato están debidamente acotados en la filosofía política de Hegel. Si bien el contrato da cuenta de una primera relación de reconocimiento entre dos voluntades, su contenido empírico sólo puede referirse a las cosas exteriores que, de suyo, son las únicas susceptibles de enajenación. Por contraste, se entiende que hay algunos bienes, (tales como la "personalidad, la universal libertad de mi voluntad, la eticidad, la religión...") (FD, §66), que no pueden formar parte de un contrato, dado que no se trata de cosas exteriores a la voluntad. En ese tenor, queda claro que la utilización del "contrato" como un "modelo discursivo" o como un "recurso teórico" que pudiera explicar las relaciones políticas propias del Estado, es algo que sencillamente está fuera de sitio. El contractualismo recurre al "contrato", según esto, para destacar la prioridad de las relaciones simétricas y horizontales entre los ciudadanos de un Estado. Se dice también que el contrato favorecería la resolución pragmática de los conflictos políticos y que puede abonar al reconocimiento de la legitimidad o validez de las leyes y del Estado vigentes, en tanto permite suponer que han sido fruto de nuestro consentimiento.

Hegel observa al respecto que la utilización del contrato no es más que una intromisión de las relaciones de la propiedad privada en el ámbito del Estado, con lo cual se traslada un tipo de relación privada a una esfera completamente distinta, donde no se trata 
de "cosas" enajenables. Esa es una preocupación que Hegel ya tenía al escribir el ensayo sobre el Derecho Natural, en donde nos previene que el "derecho civil", que sólo es "una parte" del Derecho y que rige exclusivamente en materias como la posesión y la propiedad, tiende a tomarse a sí mismo como el todo. En ese caso, el derecho civil olvida que sólo es una parte condicionada del Derecho y pretende sobreponerse al derecho político o al derecho internacional. (Cfr. DN: 101-102)

Dados los cargos que actualmente siguen pesando sobre la filosofía política de Hegel, bien vale la pena recuperar completo este pasaje del ensayo sobre el Derecho Natural, ya que allí también advierte, con el mismo énfasis, lo que podría suceder en el caso contrario; es decir

Igualmente podría querer relacionarse el Derecho político a secas, como tal, con el [individuo] singular y querer penetrar enteramente, como una perfecta policía, el ser del singular y reducir a nada, de este modo, la libertad civil: lo cual constituiría el más duro despotismo. (Ibíd.: 102) ${ }^{11}$

Con esto queda de manifiesto que, aun cuando Hegel sostenga que el Estado moderno es un fin en y por sí mismo, no es verdad que con ello se proponga o prefigure la anulación de los derechos del individuo sin más. Como hemos venido diciendo, bajo la perspectiva hegeliana, el quehacer de la filosofía se orienta precisamente a impedir que cualquiera de las partes se quede fija, se aísle y se sobreponga a las demás, ya que la filosofía se ocupa de la Idea. (Ibíd.: 103)

Toda vez que el contrato se refiere pues a la propiedad y la enajenación que las voluntades individuales ejercen sobre las "cosas", no tiene mucho qué explicar en torno a la comunidad política. Explicar las relaciones políticas propias del Estado con base en el modelo del contrato supondría que el Estado depende únicamente del arbitrio de la persona, lo que lo vuelve una institución endeble y pone en riesgo la realización de la libertad en cualquiera de sus otras configuraciones.

En la perspectiva hegeliana, la insuficiencia del contrato reside entonces en que, si bien la persona cede algo, si bien ha dado un paso hacia lo universal en cuanto reconoce que comparte su derecho individual de apropiación con otras voluntades..., todo esto lo

\footnotetext{
${ }^{11}$ La palabra entre corchetes ha sido añadida por el traductor.
} 
hace desde su libre arbitrio, al cual no está dispuesta a renunciar. En el contrato, la libertad individual reconoce que el derecho de hacer lo que le plazca y de apropiarse de las cosas del mundo tiene un límite, y ese límite consiste en respetar el derecho de las otras voluntades a esa misma posibilidad. En una palabra, la libertad individual reconoce que su derecho, además de ser suyo, es un derecho de toda otra persona. El problema es que el reconocimiento de los otros se queda en lo arbitrario y en lo contingente de la voluntad particular. Puede reconocer a los otros, pero existe la misma posibilidad de que no los reconozca. La persona que se sabe libre tiene, así, la posibilidad de enfrascarse en la realización ilimitada de su propio derecho y en la negación sin más del derecho de los otros. La voluntad particular permanece entonces en la pura inmediatez de su derecho, abstrayéndose de lo universal. Según se anota en la Observación al §81 de la $F D$, la voluntad individual renuncia, en el contrato, a disponer arbitrariamente de "todas" las cosas, puesto que reconoce el derecho de otros propietarios, pero no renuncia a la contingencia, $\mathrm{ni}$ a la arbitrariedad de su relación con ellos. De suerte que el contrato no podría servir como fundamento de una relación social firme y duradera. Las diversas voluntades particulares todavía no reconocen la "voluntad universal" como aquella realidad efectiva ante la cual deben rendir sus intereses particulares. (Cfr. FD, §86) Y es que la misma percepción de que el derecho es exclusivamente "mi derecho", comenta Houlgate, ofrece la ocasión permanente para que la persona se preocupe sólo de su propia libertad, ignorando su arraigo en la libertad universal de toda otra persona. (Cfr. Houlgate, 1995: 870)

El contrato, como acuerdo que surge del arbitrio y que versa sobre una cosa contingente, contiene al mismo tiempo el ser puesto de la voluntad accidental; ésta no es tampoco adecuada al derecho y da lugar así al entuerto [Unrecht, no-derecho] ${ }^{12}$, por lo cual, sin embargo, no queda suprimido el derecho que es en y para sí, sino que surge solamente una relación entre derecho y entuerto. (Enc. §495)

Cuando esto sucede, nos dice Hegel, surge la injusticia, que constituye la negación de lo universal. Pero, paradójicamente, será la misma injusticia la que ponga las condiciones para transitar del "derecho abstracto" a la "moralidad":

De esta manera aparece aquí la negación, que antes estaba en la voluntad existente en sí; esta negación es precisamente la injusticia. El proceso consiste en purificar a la voluntad de su inmediatez y extraer así de su comunidad la particularidad que se declara contra ella. (FD, §81, Agregado)

\footnotetext{
${ }^{12}$ Ese es el sentido del término que el propio traductor aclara en el comentario al parágrafo.
} 


\section{c. La injusticia o el no-derecho.}

Comprendida en clave de la Ciencia de la lógica, más que ser considerada como un daño que la voluntad particular le infringe al derecho universal, la injusticia es un acto de la voluntad particular que propicia que el derecho abstracto se exprese ya no como "ser", sino como mera "apariencia", favoreciendo con ello su superación. Lo aparente es aquello que sólo tiene una existencia separable de su concepto y esencia, nos dice Hegel (Cfr. Enc., §76), y esto es precisamente lo que la injusticia exhibe del derecho abstracto. A la luz del \$114 de la misma Enciclopedia, la injusticia es el acto negativo de la voluntad individual que propicia que el derecho universal se manifieste como lo "esencial" capaz de contener dentro de sí al derecho abstracto, pues la esencia sólo es tal en la medida que "...tiene en ella misma lo negativo de sí (...) Posee por tanto lo inesencial como su propia apariencia en ella misma."

Ya hemos visto que, al nivel del derecho abstracto, la libertad se reduce a un derecho personal. Decir "derecho" equivale a decir "derecho de la persona". La libertad se afianza y adquiere existencia exclusivamente como derecho particular. Esa es su existencia y no otra; ese es el "ser" del derecho en el momento del derecho abstracto. La voluntad particular se sabe libre, al tiempo que le reconoce ese mismo derecho a toda otra persona. Es decir, si bien es cierto que la voluntad particular quiere agotar el derecho en sí misma, también tiene noticia, especialmente en la figura del contrato, del derecho de las otras voluntades. El problema es que dicho reconocimiento sigue anclado en la arbitrariedad y la contingencia de la voluntad particular. En eso consiste precisamente la injusticia, en la insistencia de la voluntad particular por afirmarse como algo separado del derecho general del que ya tiene noticia.

En el ámbito del contrato y de la injusticia ya comienza en realidad a establecerse una relación con la voluntad de los demás, pero la concordancia que tiene lugar en ellos se funda en el arbitrio. Por otra parte, la relación esencial con la voluntad ajena es allí, en cuanto jurídica, sólo negativa... (FD, § 113, Observación)

Lo que cabe apreciar es que, a través de la negación de lo universal, ese "ser" del derecho se exhibe como mera "apariencia", como algo in-esencial. Entonces queda de manifiesto que el concepto del derecho universal no puede verse reducido a esa forma que se tenía a sí misma como "todo el ser" del derecho. Cuando la voluntad individual comete 
injusticia o delito, el ser del derecho abstracto queda expuesto como apariencia. Y, gracias a ello, se vuelve necesario superar el momento de abstracción de aquella primera configuración de la libertad:

La verdad de esta apariencia es que ella es nula y que el derecho se restaura por la negación de esta negación suya. ( $F D, \S 82)$

La voluntad particular se opone al derecho universal y lo niega porque percibe que puede abstraerse, porque se considera ilimitada, infinita, sumida como está en la inmediatez. En eso consiste la injusticia. Pero, en cuanto negación del derecho universal, la injusticia motiva la negación de su negación por parte del derecho y esto deja ver que, en realidad, el proceder abstracto de la voluntad particular era una ilusión. Para la voluntad particular realmente no es posible sustraerse del derecho universal, pero dicha verdad sólo llega a ser evidente cuando lo niega y se le opone, cuando comete injusticia. La injusticia favorece que lo que al comienzo sólo era tomado como algo aparente (el derecho universal) llegue a ser lo efectivamente real, puesto que "la realidad efectiva es lo que (...) se conserva en su ser otro, mientras que lo inmediato es aún susceptible de negación.” (Ibíd., Agregado)

Sabido es que Hegel estudia tres formas de injusticia: la injusticia de buena fe, el fraude y el delito. Para efectos de nuestro trabajo no es necesario revisar los detalles; es más valioso detenerse en el caso del delito, la única forma de injusticia que tiene por cometido "anular" al derecho en sí mismo: "La auténtica injusticia es el delito, en el cual no se respeta el derecho ni en sí ni como se me aparece a mí, con lo que se lesionan ambos lados, el objetivo y el subjetivo." (FD, § 90, Agregado) En el parágrafo 95 Hegel escribe también que el delito es un "juicio negativo infinito", dando a entender que no sólo atenta contra cierta persona o contra determinado bien, sino contra el derecho universal en cuando tal.

En este sentido, el delito es un acto negativo inmediato que pide ser negado por parte del derecho, exige una pena. Ahora bien, como algunos comentaristas observan, debe notarse que, en tanto que la pena es una "negación de la negación", realmente constituye una medida afirmativa cuyo fin es precisamente restablecer el derecho. Mientras que la injusticia es un acto negativo, la pena es un acto de afirmación que tiende a desvanecer la ilusión de que la voluntad particular podría agotar el derecho. La pena es el acto del derecho universal por medio del cual se declara que el derecho, aunque aparentemente haya sido 
negado por el delito, es lo eterno y lo universal, lo que se mantiene, y que es capaz de soportar lo negativo en su interior. (Cfr. Steinberger, 1988:125)

Vale la pena subrayar también que, en cuanto la pena es para Hegel una medida que restablece al derecho, al mismo tiempo es el reconocimiento del carácter racional del que comete un delito. El que comete un delito es alguien que pretende libre y racionalmente desarraigarse del derecho universal y negarlo; es alguien que ha querido identificar arbitrariamente su derecho particular como un derecho sin límites. Dado que el punto de partida de Hegel no es el dato de un ser humano atravesado por una relación de externalidad entre la razón y la naturaleza, en el caso de Hegel no hay lugar para "justificar" que alguien cometió injusticia movido meramente por lo sensible. El punto de partida en la concepción de la libertad en Hegel es un acto de abstracción, con lo que incluso la naturaleza se internaliza como lo otro-de-sí en el ser libre. De allí que, para Hegel, el recurso a las pasiones, los instintos, los sentimientos o la naturaleza para atenuar o dejar de aplicar la pena, es equivalente a negarle el carácter de un ser racional al que comete el delito. La pena o el castigo no solamente afirma el carácter universal del derecho, sino que ratifica también el carácter racional de la voluntad particular que ha tenido la ilusión de poder aislarse de lo universal. Esto propicia que la voluntad particular llegue a reconocerse a sí misma en lo universal, evitando que se pierda en lo natural. En el caso de Hegel, la pena o el castigo no se dirigen, así, contra las pasiones; no es un acto de displacer para persuadir al arbitrio, sino un acto afirmativo dirigido al carácter racional del que quiso negar lo universal.

La lesión que afecta al delincuente no es sólo justa en sí; por ser justa es al mismo tiempo su voluntad existente en sí, una existencia de su libertad, su derecho. ( $F D$, $\S 100)(. .$.$) ...en la acción misma del delincuente está la racionalidad formal, el querer$ del individuo. (Ibíd., Observación)

El sentido de la pena no consiste, de este modo, en aleccionarnos para que elijamos la ley y rechacemos las pasiones como motivos para la acción; no, el sentido de la pena es restaurar el carácter universal del derecho negado, al tiempo que afirma el carácter racional del individuo que lo niega. Disuadir al arbitrio por medio del displacer para que elija la ley puede ser importante; aleccionar al que comete un delito también podría ser conveniente para una sociedad..., pero ese no sería, en todo caso, de acuerdo con Hegel, el sentido lógico primordial de la pena. El sentido de la pena es, primero, señalar que la injusticia es una negación del derecho en sí mismo; y, segundo, disolver la ilusión de que la libertad 
podría configurarse exclusivamente como pura arbitrariedad individual. He aquí el sentido de la pena. (Cfr. Houlgate, 1995: 872)

La injusticia y la pena señalan, de este modo, el tránsito necesario del derecho abstracto a la moral. En cuanto afirmación del derecho, en cuanto castigo de la injusticia, la pena deja ver la exigencia de superar la arbitrariedad y la contingencia de la voluntad particular:

...es, pues, la exigencia de una justicia no vengativa sino punitiva. Se tiene aquí, en primer lugar, la exigencia de una voluntad que, en cuanto voluntad subjetiva particular, quiere lo universal como tal. Este concepto de la moralidad no es, sin embargo, sólo una exigencia, sino que ha surgido en este movimiento mismo. (FD, § 103)

Aquí tenemos la clave del tránsito a la moralidad. La configuración de la libertad como derecho abstracto es insuficiente porque la voluntad particular puede o no atender el derecho, porque tiende a cometer injusticia. Es entonces preciso que la voluntad quiera lo universal en sí mismo, que quiera la ley. Como veremos enseguida, la voluntad subjetiva es aquella que reconoce y hace suya la diferencia entre la arbitrariedad individual y el derecho universal. La voluntad moral es aquella que se libera de la ilusión de que el derecho está meramente al servicio de sus intereses y acepta completamente que la libertad no sólo es "su" derecho. De este modo, la moralidad supera el carácter "abstracto" del derecho, es decir, la tendencia de la libertad personal a considerar que el derecho sólo es algo suyo. La moralidad supera también la "inmediatez" o la falta de mediación entre lo universal y lo particular que describen a la persona. Supera asimismo la propensión de la voluntad individual a darse una existencia solamente en la "externalidad" de las cosas, en la propiedad. Y supera, por último, la "contingencia" o el carácter arbitrario en que la persona pretendía relacionarse con los otros. Es así como, en un movimiento interno que pasa por la vivencia de la injusticia y su negación, la propia voluntad exige que lo universal sea lo que valga como derecho y no ya la voluntad subjetiva arbitraria. (Cfr. FD, § 89) La moralidad introduce la universalidad, la mediación y la interioridad del sujeto. Pero nada de esto habría sido posible sin el impulso de la personalidad por afianzarse de modo independiente, por considerar que el derecho sólo es un derecho suyo, si no hubiese querido darse existencia apropiándose de las cosas del mundo y buscando el reconocimiento de los otros, y si no se hubiese aferrado a la contingencia y la arbitrariedad..., sin la injusticia. Esto es lo que hace 
necesaria la intervención del derecho para negar esa primera negación de lo universal, propiciando que la voluntad reflexione sobre sí y quiera directamente la ley.

De conformidad con la perspectiva que hemos querido adoptar en este trabajo, lo que conviene destacar es que el tránsito del derecho abstracto a la moralidad obedece a un tránsito necesario e interior de la voluntad misma que se realiza. Según el planteamiento lógico que subyace a la Filosofía del Derecho, Hegel nos dice que cuando un objeto es tratado filosóficamente, las determinaciones de un concepto no deben ser posiciones agregadas por el filósofo, sino el despliegue o desdoblamiento de lo que el concepto mismo implica por sí mismo. En este sentido, al filósofo le corresponde explorar el contenido del concepto que, negándose a sí mismo, transita de una configuración abstracta a otra más compleja. Y esto es lo que notamos en el paso del derecho abstracto a la moralidad. El filósofo nos hace ver que, cuando la voluntad libre se realiza como derecho abstracto, tiende a apropiarse de las cosas, que tiende a entablar contratos con las otras voluntades, pero, asimismo, tiende a negar el derecho universal, toda vez que se percibe separada..., comete delito. Y es la propia voluntad que se realiza la que demanda superar este modo de configuración, hacia uno en que sea posible que la voluntad quiera lo universal. No se trata simplemente de una crítica de Hegel a las teorías del contrato, sino también de la demostración lógica del modo en que un concepto se desenvuelve cuando es tratado filosóficamente. Es así como debiera proceder la filosofía, de acuerdo con nuestro autor. El movimiento necesario del derecho abstracto nos conduce entonces a la moralidad.

\section{LA MORALIDAD O EL DERECHO DE LA VOLUNTAD SUBJETIVA.}

Una vez que la voluntad exige salir de su abstracción, es de suma relevancia detenerse ahora en el tratamiento que hace Hegel de la configuración de la libertad como "moralidad". Esto, debido a que en su sistema hay motivos para interpretarlo como un pensador 
simplemente anti-individualista, o como alguien que habría subestimado la importancia de la conciencia y la responsabilidad subjetiva frente a las instituciones de la vida ética. En el Agregado al §145 de la Filosofía del Derecho, por citar un ejemplo, nuestro autor afirma que los individuos son algo meramente accidental con respecto a las determinaciones éticas de la libertad, es decir: la familia, la sociedad civil y el Estado. Y, bajo esta perspectiva, el individuo parecería quedar ciertamente relegado a un segundo plano; es tenido como lo noverdadero, como lo inesencial, especialmente con respecto al Estado y la historia. De allí que, para muchos de sus lectores modernos y contemporáneos, la filosofía política de Hegel no represente más que una reacción negativa frente a las ideas liberales modernas. Se ha pensado que Hegel propone un nuevo tipo de absolutismo y, dada la preeminencia de que gozan el Estado y la historia en su sistema, hay quienes incluso piensan que el planteamiento de Hegel sería una prefiguración de los totalitarismos del siglo XX. (Cfr. Cassirer, 1997: 316)

Al respecto, primeramente conviene observar que, para Hegel, la "moralidad", (lo mismo que el derecho abstracto y la eticidad), es un momento necesario del desarrollo de la idea de libertad, es decir, que la "moralidad" es una determinación específica de la libertad tan auténtica y necesaria como las otras (Cfr. §30, Observación), una determinación de la que simplemente no podría prescindirse. La segunda sección de la Filosofía del Derecho nos deja ver que, sin la configuración de la libertad como "moralidad", (que da cuenta de la infinita certeza de sí misma de la conciencia), las instituciones de la vida ética se impondrían como un poder extraño, al no ser asumidas y auto-impuestas por el sujeto. En este sentido, hay que notar que, si Hegel creyese que el Estado podría prescindir del sujeto autónomo, no le habría dado importancia a este modo subjetivo necesario en que se configura la idea de libertad. Puesto que atiende debidamente el momento de la moralidad, no cabe duda que, para Hegel, las instituciones de la vida ética requieren de la integración "reflexiva", (no coactiva, ni ciega, ni inmediata), del sujeto que les da vida.

Lo que entra en cuestión en la moralidad es el interés propio del hombre, y su elevado valor consiste en que se sabe a sí mismo absoluto y se determina. (.......el hombre que deviene interior, quiere estar él mismo en todo lo que hace. (FD, § 107, Agregado)

Esto mismo se corrobora en el $\$ 264$ de la $F D$, ya en la sección correspondiente al Estado, donde Hegel aclara que los ciudadanos que se integran conscientemente a un Estado, conservan su individualidad "que sabe y quiere por sí". La moralidad es, entonces, 
un ser-allí ineludible de la Idea de libertad; un ser-allí al que se llega, además, de modo necesario, luego de haber experimentado la inmediatez, la abstracción, la externalidad, la contingencia y la arbitrariedad del derecho de la persona. Hemos destacado que el tránsito a la moralidad se debe a las exigencias de la propia voluntad, que se niega a permanecer en una relación contingente y arbitraria con los otros, que se niega a actuar obligada meramente por una fuerza exterior y que quiere ser reconocida, más bien, como fuente de una ley universal, como una voluntad que quiere lo universal por sí mismo. En este sentido, Hegel describe el tránsito del derecho abstracto a la moralidad como un movimiento de reflexión indispensable en el proceso de realización de la voluntad libre, un proceso que va de lo in-esencial a lo esencial y de lo inmediato a su fundamento.

Por otro lado, Hegel nos deja ver en reiteradas ocasiones que la "moralidad" no es una forma secundaria de existencia de la libertad, sino precisamente aquella que marca la diferencia entre el mundo de los antiguos y el mundo moderno, ya que sólo se llega a tener conciencia de la libertad subjetiva en el momento que los individuos han superado su relación armónica e inmediata (dada, no problemática) con la comunidad que le da sentido a sus vidas; cuando han llegado a percibirse como agentes autónomos que pueden aspirar a lo universal sin la mediación indispensable de su comunidad..., algo que los antiguos no habían experimentado. La configuración de la libertad como moralidad comienza pues cuando el sujeto se concibe a sí mismo como una "libre personalidad infinita", y

Esta idea ha venido al mundo por medio del cristianismo, según el cual el individuo en cuanto tal tiene un valor infinito por cuanto siendo él objeto y fin del amor de Dios, está destinado a tener su relación absoluta con Dios en cuanto espíritu y tener ese espíritu en su interior, esto es, que el ser humano está en sí determinado a la libertad suprema. (Enciclopedia, §482, Nota)

De acuerdo con Hegel, entonces, la libertad subjetiva es una configuración imprescindible; se trata de una determinación necesaria tanto lógica como históricamente hablando, un ser-allí irrenunciable en el proceso de autoproducción de la voluntad libre. De modo que aquel primer anti-individualismo y la mera exaltación del Estado que parecerían agotar su pensamiento político, bien pueden matizarse o, por lo menos, entenderse de otro modo. 
Lo que tampoco se puede ignorar, ciertamente, es que Hegel expone, además, una postura crítica frente a la convicción de que la libertad podría reducirse a su configuración subjetiva.

Sólo en el sujeto puede realizarse la libertad, pues es el verdadero material para esa realización. Esta existencia de la voluntad, que llamábamos subjetividad, es, sin embargo, diferente de la voluntad existente en y por sí. [De modo que] La voluntad tiene que liberarse de esta nueva unilateralidad de la mera subjetividad para devenir voluntad existente en y por sí. (FD, § 107, Agregado)

\section{LA LIBERTAD DEL SUJETO.}

En su tránsito del derecho abstracto a la moralidad, la voluntad realiza un movimiento "reflexivo", superando con ello su expresión solamente exterior. Nos parece que este movimiento es el mismo que Hegel había descrito en la Fenomenología del espíritu. Allí, la moralidad corresponde al estadio del "espíritu cierto de sí mismo", uno en donde la conciencia "...es absolutamente libre porque sabe su libertad, y precisamente este saber de su libertad es su sustancia y su fin y su único contenido." (FE, p. 353) En la Filosofía del Derecho, por su parte, la moralidad es el momento en que el derecho se determina como "subjetividad", donde las exigencias del derecho universal dejan de ser algo ajeno e impuesto, porque la voluntad subjetiva no sólo quiere lo universal, sino que incluso se concibe como su fuente; es entonces que la persona se determina como sujeto. (Cfr. FD, $\S 105)$

En la configuración de la libertad como "derecho abstracto" la persona sólo cumple con ciertas reglas y prohibiciones formales que le son impuestas por algún poder extraño. Allí no importan pues las convicciones internas que la persona pueda tener para actuar. El dar razones del propio actuar pertenece entonces a otro ser-allí de la libertad, pertenece al terreno de la voluntad subjetiva.

El punto de vista moral es, por lo tanto, la figura del derecho de la voluntad subjetiva. Según este derecho, la voluntad es y reconoce sólo lo que es suyo, es decir, aquello en lo que ella existe como algo subjetivo. (FD, §107)

Vuelve a ser claro el valor que esta forma de existencia de la libertad adquiere para Hegel. Siguiendo a Kant, Hegel confirma que la "convicción" interna del ser humano es algo 
que no se puede invadir, algo sobre lo que no se puede ejercer ningún tipo de violencia. (Cfr. FD §106, Agregado). La configuración de la libertad como moralidad se refiere, entonces, a un ámbito que ni siquiera la comunidad política, (aunque constituya lo sustancial de la libertad en la filosofía práctica hegeliana), puede ni debe invadir.

La configuración de la libertad como moralidad tiene una serie de determinaciones que conviene revisar, ya que Hegel registra aquí diversos movimientos lógicos que también contribuyen a la comprensión de su modo peculiar de ocuparse filosóficamente de la libertad.

Nuestro autor anota, por ejemplo, que la subjetividad es pura "autodeterminación infinita" y que en esto consiste, justamente, el aspecto formal de la voluntad. Sin embargo, puesto que tal autodeterminación es la de una "voluntad individual existente" que se sabe distinta de la autodeterminación en sí, el punto de vista moral se determina, además, como puro deber ser. Y, por último, dado que la subjetividad es aquella que se diferencia del lado objetivo y que quiere oponerse a lo exterior dado, la voluntad subjetiva también posee la determinación de ser una conciencia finita que aparece en el mundo fenoménico. Aquí tenemos entonces tres elementos descriptivos de la voluntad subjetiva: es "lo formal" y es "deber-ser", pero es también una voluntad que "aparece" en el mundo. (Cfr. FD, §108)

Vale la pena subrayar lo que Hegel entiende aquí por "lo formal" de la voluntad subjetiva. Es claro que el aspecto "formal" de la moralidad no amerita ningún tipo de crítica por sí solo. Al contrario, "lo formal" es expuesto como un rasgo irrenunciable de la voluntad subjetiva, como el aspecto que la define. En cuanto autodeterminación infinita, "lo formal" es justamente el aspecto inmanente de una voluntad subjetiva que se sabe auto-legisladora. Habría que comprender entonces que, si Hegel advierte más tarde que la moralidad sólo se determina como un "formalismo", no se debe a que le asigne una mayor importancia a los "contenidos materiales" dados, sino a que vislumbra que la vida ética constituye el modo más adecuado de autodeterminación, uno en donde lo "formal" (es decir la autodeterminación infinita) se concreta cabalmente, haciendo posible incluso la realización de la libertad en todas sus configuraciones precedentes. Deshacerse de "lo formal" sería equivalente a renunciar a un aspecto básico de la libertad, pero no transitar a la concreción de "lo formal" que se alcanza en la vida ética equivaldría a quedarse con un modo todavía abstracto (no mediado) de autodeterminación. Si se toma como referencia el 
perfeccionamiento lógico que va de lo "in-esencial" a lo "esencial que se media a sí mismo", es claro que solamente la eticidad cumple con esta última determinación de lo esencial, mientras que la voluntad subjetiva tiende a encerrarse en la universalidad de su pura interioridad.

El otro con que está en relación la voluntad subjetiva tiene un doble carácter: es, por un lado, lo sustancial del concepto y por otro lo existente exteriormente. Aunque lo puesto en la voluntad subjetiva fuese el bien, no estaría por ello todavía realizado.

(FD, §108, Agregado)

Volviendo a las determinaciones de la voluntad subjetiva, vemos que Hegel expone también el movimiento dialéctico que le permitiría a la voluntad subjetiva superar la mera contraposición inicial con la objetividad. Esta dialéctica consta de tres momentos: en el primero de ellos, el sujeto se percibe como pura reflexión infinita capaz de negar todo lo objetivo que se le interpone como un límite externo, ya que los límites son algo inaceptable para una voluntad que se sabe auto-legisladora. En un segundo momento, la voluntad reconoce que eso finito exterior es un límite "suyo" al que desea traspasar, porque quiere realizarse en el lado objetivo. Pero en este movimiento de poner lo subjetivo en lo objetivo, la voluntad se percata de que su identidad consigo permanece en todo momento, y es así como se da un "fin" determinado en el cual se reconoce a sí misma, reuniendo con ello los lados que aparecían primeramente como algo simplemente contrapuesto; este es el tercer momento. Aquí tenemos pues la triada de la infinitud, lo finito y el fin, a la que Hegel se refiere con los términos lógicos de la identidad, la diferencia y la oposición en la identidad. (Cfr. FD, §109) Como Rosenfield señala, lo que sucede en este movimiento es que "El noser de su exterioridad deviene el ser-otro de su interioridad." (Op. cit.: 111)

Es este tipo de procedimiento el que le permite a Hegel pensar los aspectos subjetivo y objetivo siempre como mutuamente dependientes. Pero se trata de un desarrollo que no encontramos en Kant, quien piensa primero en uno de los términos (el sujeto y su autonomía formal), luego en el otro como un ámbito aislado (el mundo objetivo), y al final su relación como un tercer elemento distinto a los primeros dos. Es por eso que, en la filosofía práctica de Kant, tanto en su punto de partida, como en sus conclusiones, la relación sujetoobjeto no pasa de ser un contacto externo y accidental. En la propuesta de Kant, lo primero es demostrar la capacidad subjetiva de auto-legislación, pero esto obliga a que el sujeto se relacione externamente incluso con su propia naturaleza, que le resulta siempre ajena. Lo 
"otro" nunca llega pues a ser pensado como lo "otro-de-sí", sino simplemente como un otro en toda su exterioridad.

En los $\S \S$ del 110 al 113 tenemos, por último, los componentes de la "acción moral", a saber: 1) la acción moral debe ser sabida como un contenido propio de la voluntad subjetiva, como algo mío; 2) la acción moral tiene que relacionarse con el concepto en la forma de un deber-ser, no importando su contenido particular, y 3) la acción moral debe permitirle a la voluntad superar la subjetividad inmediata, propiciando una relación positiva con los otros.

Todas estas determinaciones de la voluntad subjetiva revelan que, si bien lo característico del tránsito del derecho abstracto a la moralidad es un movimiento "reflexivo" hacia la interioridad, también es cierto que el sujeto de la moralidad, al igual que la persona del derecho abstracto, quiere darse una existencia, quiere ser-para-otro. Hemos visto que a la persona no le bastaba con saberse poseedora de un derecho ilimitado, sino que era igualmente importante que su derecho fuese reconocido por los otros en la existencia. Esto mismo sucede con el sujeto del deber moral: no le basta con saberse "interioridad infinita", con saberse autodeterminado, sino que quiere "actuar" en el mundo fenoménico y quiere tener una relación positiva con las otras voluntades auto-legisladoras. La voluntad subjetiva sabe y quiere lo universal, pero también es práctica, es finita y busca particularizarse por conducto de la acción. Cabe adelantar que con este impulso de la voluntad subjetiva al actuar surge una serie de contradicciones que no siempre se resuelven apropiadamente en el ámbito de la moralidad.

Hay diferencias, por supuesto, entre la persona y el sujeto en lo que a la relación con los otros y el actuar se refiere. En la moralidad, la relación con los otros ya no tiene como motivo la propiedad y el intercambio de "cosas", sino que ahora se trata de un deber, el deber de actuar racionalmente y de reconocer a los otros como seres racionales. Ya decíamos que para la persona del derecho abstracto, la diferencia entre lo universal y lo particular no era clara, porque allí el derecho se agotaba en "su derecho". La voluntad moral, en cambio, "acepta completamente que la libertad no sólo es propia, sino que es algo universal en sí misma." (Houlgate, 1995: 872)

El concepto de la moralidad es el interno relacionarse consigo de la voluntad. Pero aquí no hay sólo una voluntad, sino que su objetivación tiene al mismo tiempo la determinación de que en ella se elimina la voluntad individual, por lo cual, al 
desaparecer la determinación de la unilateralidad, resultan puestas dos voluntades y una relación positiva de una a la otra. (FD, §112, Agregado)

Existe otra notoria diferencia en el modo de particularizarse, pues cuando la persona ejerce su derecho, cuando se apropia de las cosas del mundo, no duda que su apropiación es completa. La persona se apropia de las cosas, establece contratos e incluso comete delito, sin percibir que algo se le escapa. Cuando la voluntad subjetiva se particulariza, en cambio, una y otra vez encuentra que lo particular no termina de ajustarse con lo universal (con el deber-ser), de lo que ahora sí tiene conciencia. La voluntad subjetiva experimenta pues una permanente disparidad entre lo universal y lo particular, entre su interior y lo existente, el deber-ser y lo contingente... Y semejante desencuentro es palpable en todas las expresiones de lo que Hegel denomina "el derecho de la voluntad moral". Así como la persona se expresaba en la propiedad, el contrato y el delito al ejercer su derecho, así el sujeto se expresa en las figuras del "propósito y la responsabilidad", "la intención y el bienestar" y, finalmente, "el bien". Pero una nota constante y muy propia del punto de vista moral es que el sujeto moral siempre duda que lo universal logre realmente particularizarse, de que lo interior pueda ser puesto efectivamente en lo exterior y lo subjetivo llevado a la objetividad. La voluntad subjetiva sabe cómo debiera ser el mundo y sabe que el mundo es obra suya, pero al mismo tiempo considera que éste "no es" cabalmente como ella se representa que "debiera ser". A la voluntad moral se le dificulta pues determinarse apropiadamente; o bien, su determinación termina siendo la indeterminación. De allí que, en la configuración de la libertad como moralidad, aun cuando la voluntad es práctica y quiere objetivarse, lo universal es algo que tiende a quedarse en el interior, del lado subjetivo.

Por eso revisaremos ahora, brevemente, las expresiones del derecho de la voluntad moral, ya que allí encontramos también las contradicciones que luego exigen que se transite a un ser-allí de la libertad más adecuado a su concepto.

\section{a. El propósito y la responsabilidad.}

Dado el interés por actuar, la figura del "propósito y la responsabilidad" da cuenta de la contradicción que la voluntad subjetiva experimenta entre lo necesario y lo contingente del acto y sus consecuencias. La voluntad subjetiva vive un conflicto cuando, sabiéndose 
autodeterminada (es decir, portadora de fines necesarios y universales), debe actuar, sin embargo, en un mundo dado (o sea, contingente). La voluntad subjetiva se plantea pues fines racionales, pero en medio de circunstancias preexistentes que le impiden tenerlo todo bajo control, especialmente las consecuencias imprevistas de sus actos.

Surge entonces un problema, el de averiguar qué es exactamente lo que puede adjudicarse a la voluntad subjetiva. De toda acción se desprenden consecuencias que, en principio, le pertenecen; sin embargo, también es cierto que la acción está condicionada por fuerzas que le son completamente ajenas. ¿Qué consecuencias podrían entonces imputársele al sujeto con toda seguridad? ¿De qué cosa es responsable? Lo que Hegel nos dice es que el derecho de la voluntad moral es precisamente el de no aceptar como "su responsabilidad" sino lo que ella misma ha previsto:

El derecho de la voluntad consiste en que en un hecho suyo sólo se reconozca como su acción propia y sólo tenga responsabilidad sobre aquello que ella sabía en su fin acerca del objeto presupuesto, es decir lo que estaba en su propósito. (FD, §117)

En este sentido, la figura del "propósito y la responsabilidad" es otra seña de la transformación histórica en el modo de concebir la libertad: en el mundo moderno, la voluntad subjetiva exige saber de qué consecuencias es responsable; lo que sucede en el mundo ya no se explica entonces en función del "destino", como pasaba entre los antiguos.

El tratamiento lógico de esta contradicción entre lo necesario y lo contingente nos dice, sin embargo, que las "consecuencias" no deben ser completamente ignoradas, (puesto que pertenecen a la naturaleza de la acción), ni ser tampoco el único criterio para juzgarla, (pues están sometidas a fuerzas contingentes). Lo más adecuado, de acuerdo con Hegel, es pensar dialécticamente, un procedimiento que nos permite reconocer lo necesario en lo contingente, y viceversa. Nuestro filósofo explica un movimiento semejante en el $\$ 149$ de la Enciclopedia, del siguiente modo:

Lo que es necesario es por medio de otro (...), un contingente que al mismo tiempo es condición. Lo necesario, en cuanto es por otro, no es en y para sí, sino un mero puesto. Pero esta mediación es también inmediatamente la superación de sí mismo...

La figura del "propósito y la responsabilidad" revela entonces que, al actuar, la voluntad subjetiva, (que es, ciertamente, portadora de lo universal), debe entregarse a la 
finitud, la inmediatez y la contingencia de un mundo dado, y mediarse en ella, porque es allí donde puede realizar su propósito. Así, lo contingente llega a reconocerse como lo-otro de la necesidad, al tiempo que la necesidad reconoce que requiere de ese su-otro para mediarse y aparecer en la existencia. Hegel advierte que "actuar quiere decir [precisamente] entregarse a esta ley." (§118, Observación) Esto conlleva que, en la existencia, las acciones implican la contingencia. La contingencia no debiera ser vista entonces como algo simplemente ajeno a la necesidad, ni la necesidad como algo que pudiera evadirse de la contingencia.

\section{b. La intención y el bienestar.}

En la figura de la "intención y el bienestar", la otra expresión de la voluntad moral que actúa, surgen nuevas relaciones de contradicción, esta vez entre lo singular y lo universal, y entre lo particular y lo universal, mismas que a Hegel también le interesa revisar. A su juicio, la moralidad kantiana no resuelve adecuadamente ninguna de estas contradicciones, pues en su caso los términos se afianzan simplemente como aspectos contrapuestos, ajeno el uno del otro, según hemos dicho ya.

Conforme al "derecho de la intención", la voluntad moral exige querer y reconocer lo universal que contiene su acción, no importando el aspecto singular o empírico de la misma. "El propósito atañe solamente a la existencia inmediata, pero la intención se refiere a lo sustancial y al fin de esa existencia." (Enc., §505) Al estudiar la "intención" Hegel parece entender lo singular como aquello que sólo se percibe por medio de los sentidos, lo que existe externamente, lo múltiple. Y sucede que, cuando la voluntad actúa, su acción está determinada inicialmente por estos rasgos empíricos de la singularidad: es múltiple, sensible y externa. Hegel ya nos decía, sin embargo, que un elemento de toda "acción moral" es el estar esencialmente ligada a lo universal, a pesar de su componente empírico. Pues en esto consiste precisamente el derecho de la voluntad moral representado en la "intención", en afirmar que

...la verdad de lo singular es lo universal, y la determinación de la acción no es por sí un contenido aislado en una singularidad exterior, sino un contenido universal que contiene en su interior una conexión múltiple. (FD, §119) 
Como puede verse, lo singular y lo universal, que primeramente surgen como aspectos contrapuestos en la figura de la "intención", realmente no pueden verse separados, de acuerdo con Hegel. El sujeto moral parece exigir que, de su acción, se aísle sólo el aspecto determinado como lo universal pensado y sabido por ella. Este es ciertamente el derecho de la voluntad moral porque en ello descansa la libertad subjetiva, la capacidad de agencia y el reconocimiento del sujeto moral como un ser pensante. Con todo, Hegel señala que "En lo viviente, lo singular no existe como parte sino como órgano en el que está presente lo universal como tal..." (Ibíd., Observación) Nuestro autor se vale aquí de un argumento traído del organicismo, pero que tiene al menos un par de implicaciones: primera, que el querer separar lo universal de lo singular sería un acto arbitrario y, segunda, que lo universal de la voluntad moral se engendra, en todo caso, en lo singular mismo: “......al actuar el hombre se entrega a la exterioridad." (Ibíd., Agregado) De nueva cuenta, el procedimiento lógico seguido por Hegel evita que nos quedemos con uno sólo de los componentes de la acción moral: primero acentúa lo irrenunciable del aspecto universal de la voluntad moral que se afirma en la "intención", pero luego advierte que este lado subjetivo no debiera separarse arbitrariamente de lo singular de su acción, sino reconocerse y realizarse precisamente allí. La figura de la "intención" nos enseña, de este modo, que lo propio del sujeto moral es comprobar interiormente la forma en que se auto-determina; sin embargo, dicha auto-determinación ocurre necesariamente en el mundo fenoménico.

Y este resultado nos conduce a la otra expresión de la voluntad moral, a la figura del "bienestar", donde Hegel atiende la relación contradictoria entre el aspecto universal y el particular que contiene la acción moral. Hemos dicho que, de acuerdo con Hegel, lo universal se expresa necesariamente en lo particular, pero la moralidad no parece concebirlo cabalmente de ese modo. La moralidad se aferra a la mera contraposición entre la ley moral y los impulsos naturales, el deber y la felicidad, la acción autónoma desinteresada y la acción heterónoma interesada, lo universal y lo particular... El modo en que Hegel aborda la figura del "bienestar", en cambio, supone que la libertad también está en juego cuando la voluntad particular persigue su propio interés. Hegel no piensa que la acción moral, para ser tal, deba prescindir de los intereses particulares. Según su concepción de la voluntad libre, la acción del sujeto moral consiste precisamente en reunir lo universal y lo particular.

...mi libertad convertida en contenido de mi voluntad es una determinación pura de mi propia libertad. El más elevado punto de vista moral es, por lo tanto, encontrar la 
satisfacción en la acción, y no permanecer en la ruptura entre la autoconciencia del hombre y la objetividad del hecho. (FD, §121, Agregado)

Como puede apreciarse, la figura del "bienestar" pone al descubierto otro de los aspectos polémicos entre la filosofía práctica de Hegel y la de Kant. Para éste último, el interés particular no debiera mezclarse en la acción autónoma, dado que la voluntad actúa moralmente cuando quiere cumplir la ley por la ley, sin importar el bien, el propósito, el efecto, la finalidad o el objetivo particular que el sujeto pueda encontrar en ello. Cuando Kant separa la felicidad y el deber, lo hace precisamente en términos de una mera oposición, porque piensa que el fin práctico supremo de la razón es el de formar una voluntad buena, y eso conlleva renunciar a las inclinaciones naturales. Palabras más, palabras menos, lo que Kant propone en la segunda Crítica es que la razón tiene que presentarle a la voluntad los preceptos dignos de respeto que habrán de debatirse contra todas aquellas necesidades e inclinaciones que sólo aparentan conducirnos a la felicidad. El filósofo de Königsberg afirma una y otra vez que el principio de la felicidad, (por más que en él se use del entendimiento y la razón), no contiene para la voluntad ningún otro fundamento de determinación que el de la facultad de desear de acuerdo a un objeto. De suerte que, aunque el "ser feliz" es un anhelo de todo ser racional finito, y por tanto, fundamento de determinación de su facultad de desear, es imposible considerarlo una la ley moral. Kant defiende pues que:

...existen realmente leyes morales puras que determinan enteramente a priori (con independencia de motivos empíricos, esto es, de la felicidad) lo que hay y lo que no hay que hacer, es decir, el empleo de la libertad de un ser racional en general... (CrPu, B 835)

Es posible relacionar la felicidad con la moralidad, añade Kant, pero sólo en un mundo inteligible. La relación de la felicidad y la moralidad no es entonces más que una idea cuya realización dependería de que "todas las acciones de seres racionales sucedan como si procedieran de una suprema voluntad que comprendiera en sí o bajo sí todas las voluntades privadas." (Ibíd., B 838)

Para Hegel, en cambio, existen al menos dos motivos para no dejar de lado el aspecto particular de la voluntad en una configuración adecuada de la libertad. Según el primero de estos motivos, no es que Hegel proponga que la búsqueda de la felicidad puede ser una ley práctica, un deber, pero sí tiene claro que la voluntad subjetiva se determina, necesariamente, en su "existencia subjetiva natural", es decir, en la búsqueda del bienestar o la felicidad como su fin. (Cfr. FD, §123). Aquí debe aclararse, sin embargo, que atendiendo al 
tratamiento filosófico de la voluntad que se realiza, "el bienestar o la felicidad" nunca son equiparables con el mero impulso natural. Los impulsos e inclinaciones nunca son meramente algo "otro" de la voluntad, sino que han sido mediadas desde el comienzo como el fin particular de una voluntad que es "finita", sí, pero que también es "reflexiva". De este modo, el bienestar o la felicidad no corresponden a un contenido extraño que provenga de la naturaleza, (como Kant parece tomarlos), sino que se trata de demandas que el aspecto formal de la voluntad subjetiva ha hecho suyas desde el comienzo y, por ende, lo universal de la voluntad también se realiza en esos fines particulares que responden a lo natural mediado, por heterónomos que parezcan.

Y el segundo motivo para no deshacerse del aspecto particular nos indica que, aun cuando la voluntad libre consiga abstraerse de todos sus deseos e inclinaciones dadas, todavía le queda precisamente aquel interés que la hace una voluntad: el deseo de ser libre. Según la sugerencia de Alan Patten, ese es precisamente el sentido exacto del §21 en la FD. (Cfr. Patten, 2002: 98) Dicho en otra terminología, lo que Hegel piensa con ocasión de la figura del "bienestar" es que lo universal requiere necesariamente de la mediación del sujeto y de sus fines particulares, porque

Lo ético concierne al contenido que, en cuanto tal, es lo universal (algo inactivo) y que tiene en el sujeto aquello que lo activa. (Enc., § 475, Nota)

Al demostrar que la acción del sujeto es precisamente la que reúne lo universal y lo particular, Hegel parece cerrar, además, un ciclo abierto en el momento del "derecho abstracto". El tránsito del derecho abstracto a la moralidad es un tránsito necesario porque, cuando la persona sólo se ocupa de sus intereses particulares, su querer es arbitrario; por eso exige querer lo universal. En la moralidad, por contraparte, la figura del "bienestar" nos deja ver que lo universal requiere de lo particular (es decir, del interés particular de la voluntad subjetiva), para darse una existencia. Lo uno requiere (necesariamente) de lo otro.

Pero lo que interesa destacar aquí es que este resultado sólo es posible para un planteamiento que se atiene al despliegue dialéctico inmanente del concepto; "La reflexión abstracta, por el contrario, fija este momento [de lo particular] en su contraposición y diferencia con lo universal, dando lugar así a una visión de la moralidad que la presenta como una lucha contra la satisfacción propia..." (FD, §124, Observación) 
Debe anotarse, por último, que tampoco es que Hegel exalte el interés particular en sí mismo, sino que, al estar ubicado en la moralidad, éste ha cobrado dimensiones intersubjetivas. La subjetividad es particular y universal a la vez. Por eso piensa que el bienestar de los otros también es "un fin esencial y un derecho de la subjetividad." (FD, §125) Ya no estamos pues en la esfera del derecho abstracto, sino en la moralidad, y aquí la relación de la voluntad subjetiva con los otros es una relación positiva. Ahora, la voluntad subjetiva quiere lo universal en sí mismo y es capaz de poner incluso "la vida" y el "derecho de emergencia" por encima de las meras reglas del derecho abstracto.

Es así como llegamos a la figura del "bien", la última de las expresiones del derecho de la voluntad moral.

\section{c. El bien.}

Hemos insistido en que el tránsito del derecho abstracto a la moralidad es necesario porque la persona debe superar el carácter arbitrario e inmediato en el modo de ejercer su derecho; es preciso que la "particularidad" (de la persona) salga de su abstracción y se medie en la "universalidad". Lo que acabamos de presenciar en la figura del "bienestar", sin embargo, es que la voluntad subjetiva que "quiere lo universal" tampoco puede quedarse únicamente en el aspecto formal e inmanente de la voluntad, es decir, en la mera posibilidad de la autodeterminación infinita. Por tratarse de una conciencia finita que actúa, ésta requiere mediarse obligadamente en la particularidad. Es decir, aquí el aspecto "universal" (de la voluntad subjetiva) debe salir de su indeterminación. Así tenemos que, con la superación del derecho abstracto en la moralidad, la voluntad alcanza la mediación de lo particular en lo universal, en tanto que la acción del sujeto moral es precisamente aquella que quiere poner lo universal en lo particular.

Es en este sentido que el "bien" se nos presenta como un momento de unidad en el que las configuraciones precedentes alcanzan su mediación. Puesto que expresa el derecho de una voluntad "particular" que quiere lo "universal", la categoría del "bien" es el resultado interno del proceso dialéctico en el que ambos aspectos rebasan su carácter independiente, unilateral y abstracto: 
El bien es la idea como unidad del concepto de la voluntad y de la voluntad particular. Tanto el derecho abstracto como el bienestar y la subjetividad del saber y la contingencia de la existencia exterior están eliminados en el bien en cuanto independientes por sí, pero al mismo tiempo están contenidos y conservados en él según su esencia. (FD, §129)

El "bien", la última de las expresiones del derecho de la voluntad moral, consiste en "reconocer como válido" solamente aquello que se considera "bueno". (Cfr. FD, §132) Esto conlleva que la voluntad moral ejerce un poder de negación sobre todo aquello que no considera "bueno". Ahora bien, en tanto que la voluntad moral es aquella que quiere lo universal, es claro que el contenido de lo "bueno" ya no se refiere simplemente al interés individual. Habíamos visto que la persona del derecho abstracto también ejerce un poder de negación sobre lo dado, pero hicimos notar también que su negación responde a intereses meramente individuales. Cuando el sujeto moral rechaza lo dado, en cambio, lo hace en función del "bien", una expresión que, de acuerdo con Hegel, reúne el "concepto de la voluntad" y "la voluntad particular", lo universal y lo particular. En principio, la voluntad moral no niega pues al mundo de manera arbitraria, sino solamente cuando éste no responde a lo universal sabido y querido por ella. El sujeto moral es precisamente aquel que exige comprobarlo todo, pero bajo el criterio de lo universal; es aquel que no acepta lo irracional. En el Prefacio a la Filosofía del Derecho Hegel ya nos adelantaba que el "pensamiento libre", esa configuración característica de la modernidad, no acepta ninguna de las figuras de lo inmediato: ni lo que descansa en la autoridad positiva del estado, ni lo que se apoya en el consenso de los hombres, ni en el sentimiento, ni en la aprobación inmediata del espíritu... (FD, Prefacio, p. 42) Al sujeto moral no le basta pues con describir o aceptar lo existente, sino que exige concebir su verdad y comprenderla, exige que sea "bueno", racional, universal. "El derecho de no reconocer lo que yo no considero racional es el más elevado derecho del sujeto...” (FD, §132, Observación)

En el transcurso del presente apartado hemos venido revisando, con Hegel, el modo en que la voluntad libre se despliega dialécticamente en su existencia; es decir, las distintas configuraciones que la voluntad libre adopta cuando actúa en el mundo. Ahora que nos encontramos en la figura del "bien", nos parece que existe alguna semejanza con lo que John Stuart Mill considera el deber de un pensamiento libre, cuando afirma que "Nadie puede ser un gran pensador sin reconocer que su primer deber, como tal, consiste en seguir a su inteligencia, cualesquiera que sean las conclusiones a que se vea conducido." (Mill, 
2007 [1859]: 98) Como se sabe, al pensador londinense le preocupaba profundamente la opresión que el poder político, la religión, la ley, las costumbres y las opiniones sociales podían ejercer sobre la libertad del individuo particular; por eso dedica buena parte de su obra a defender la necesidad y la importancia del "pensamiento libre". Como se hace patente en el pasaje que acabamos de citar, bajo su perspectiva es de vital importancia que el "pensamiento libre" individual se ejerza, no importando si su ejercicio desata crisis en las estructuras establecidas de la vida social. De allí que Sócrates, Jesucristo y Lutero le sirvan como modelos de esta forma de libertad.

En un sentido similar, decimos, Hegel describe al "bien" como aquel derecho de la voluntad moral que exige juzgar todo lo existente. Más aún, Hegel parece afirmar que los cambios históricos se deben justamente a esta expresión del derecho de la voluntad moral:

...todo lo que reconocemos como derecho o deber puede ser señalado por el pensamiento como algo nulo, limitado y de ninguna manera absoluto. Pero, dado que todo contenido se disuelve en ella, la subjetividad debe desarrollarlos nuevamente a partir de sí. Todo lo que surge en la eticidad es producido por esta actividad del espíritu. (FD, §138, Agregado)

Así se confirma pues el carácter necesario de esta forma de existencia de la libertad. En un abierto reconocimiento a la filosofía práctica de Kant, nuestro autor afirma que la voluntad sólo es libre en la medida que su verdad, su esencia y su único deber es el "bien": "Debo cumplir con el deber por el deber mismo, y lo que realizo en el deber es mi propia objetividad, en sentido verdadero: cumpliéndolo estoy conmigo mismo y soy libre." (FD, $\S 133$, Agregado)

Es aquí mismo, en la cima de la moralidad, sin embargo, donde Hegel encuentra que la configuración de la libertad como moralidad es un ser-allí insuficiente.

\section{LOS LÍMITES DE LA MORALIDAD.}

Al ocuparse del despliegue de la voluntad en su existencia, Hegel encuentra que la moralidad es una configuración igualmente insuficiente de la libertad. Primeramente, porque no logra superar su carácter puramente subjetivo. Puesto que aquí la definición del "bien" 
descansa únicamente en el juicio del sujeto, la libertad se restringe a su aspecto formal, es decir, a la autodeterminación infinita de un sujeto que sabe en su interior lo que es el bien, pero que se percibe separado de la objetividad. Sin embargo, el sujeto no puede ser el único que defina lo que es el "bien”, porque su “...apreciación puede ser tanto verdadera como una mera opinión y error." (FD, §132, Observación)

En segunda instancia, la configuración de la libertad como moralidad resulta insuficiente, a los ojos de Hegel, debido a la pervivencia de una separación entre la conciencia finita y el "bien" en cuanto tal. El punto de vista moral coloca de un lado al "bien", como lo universal querido y sabido por el sujeto, y de otro a la propia conciencia moral existente, depositaria de ciertos intereses particulares. Así las cosas, la voluntad moral no lograría infundirle una finalidad universal a sus actos particulares, y esto es precisamente lo que se pretendía lograr en la moralidad. (Cfr. Rosenfield, 1989: 128)

En estrecha relación con este último punto, Hegel encuentra que la moralidad adopta entonces una expresión abstracta, toda vez que el "bien" se entiende básicamente como el cumplimiento del deber, como pura "universalidad abstracta". (Cfr. FD, §135) Si en el momento del "derecho abstracto" era el aspecto particular el que carecía de mediación, aquí la abstracción radica en que la moralidad apela exclusivamente al aspecto universal de la auto-legislación. En esto consiste, como sabemos, el señalamiento hegeliano de que la moralidad no es más que un "formalismo vacío".

Dicho tópico ya se ha discutido ampliamente en la bibliografía especializada; en cambio, se han dejado de lado otros aspectos, como es el señalamiento de que la propia conciencia moral evita someterse a la crítica. En el momento de la moralidad se logra establecer que la conciencia moral sabe en su interior lo que es el derecho y el deber, lo que es el "bien", pero ella misma no se somete al juicio de si es o no verdadera. Lo que Hegel extraña en este caso es que el punto de vista moral no ejerza el poder de negación sobre la propia voluntad subjetiva, para evitar así una nueva configuración arbitraria del derecho. Como dijimos previamente, Hegel destaca la importancia del "principio supremo de la moralidad" alcanzado por Kant, pero al mismo tiempo le reprocha que no prosiga con la dinámica de la negación de toda determinación unilateral. De acuerdo con Hegel, el proceso de negación debiera pues aplicarse incluso sobre la universalidad formal que define a la moralidad. 
La conciencia moral está, por lo tanto, sometida al juicio de si es o no verdadera, y su apelación exclusiva a sí misma se opone inmediatamente a lo que ella quiere ser: la regla de un modo de actuar racional, universal y válido en y por sí. (FD, §137 Observación)

Hegel habla incluso en este punto de dos conciencias morales: una es la conciencia de la moralidad que sólo afirma el aspecto formal de la autonomía individual y otra es la conciencia de la vida ética, que quiere "lo que constituye en y por sí el bien y el deber". (Ibíd., Agregado) La conciencia de la moralidad es abstracta y se la puede distinguir de aquella que se auto-determina en la vida ética. De lo contrario, (y esto nos coloca en otra de las limitaciones que Hegel encuentra en la configuración de la libertad como moralidad), el derecho de la voluntad moral puede adoptar una expresión extrema y, en aras del "bien", ser capaz de disolver cualquier determinación del derecho, pero siempre con referencia exclusiva a sí misma y no necesariamente a lo racional y objetivo. Lo que preocupa a Hegel en este caso es que el derecho se afirme nuevamente de modo unilateral.

...la autoconciencia es posibilidad de convertir en un principio tanto lo en y por sí universal, como el arbitrio, de hacer predominar la propia particularidad sobre lo universal, y de realizarla por medio de su actuar; en otras palabras, tiene la posibilidad de ser mala. (FD, § 139)

La configuración de la libertad como moralidad es un punto de vista culminante de la vida moderna. Representa el derecho de juzgarlo todo y de no aceptar sino aquello que se valore como racional. En este momento se demuestra que el sujeto moral es capaz de autolegislar y que sólo es libre en la medida que quiere lo universal y que actúa bajo la guía de una ley auto-impuesta. Pero, al ejercer su derecho, la conciencia moral puede adoptar igualmente ciertas "formas degradadas" (Rosenfield), como cuando pretende justificar su acción solamente porque tiene una "buena intención", o cuando arguye que actúa porque al menos está "convencida" de hacer el bien, cuando es "hipócrita" o cuando es "irónica". En la última de dichas formas, "lo superior no es la cosa, sino yo; yo soy el señor que decide sobre la ley y la cosa, y juego con ellas como con mi capricho..." (FD, §140, Observación)

Así pues, la voluntad subjetiva es el momento de la autonomía, pero también es el momento del engaño y del auto-engaño. La configuración de la libertad como moralidad posibilita que la voluntad reconozca y haga suya la diferencia entre la arbitrariedad individual y el derecho universal. En la moralidad se supera ciertamente la falta de mediación de lo particular que caracteriza a la persona del derecho abstracto. Se supera, asimismo, la 
propensión de la voluntad individual a darse una existencia meramente "externa" en la propiedad de las cosas. Y se supera, en suma, la "contingencia" o el carácter arbitrario con el que la persona pretendía relacionarse con los otros. Aun así, Hegel no deja de observar que la voluntad moral sigue siendo abstracta cuando se aferra a ser ella, en su interior, la responsable única y última del reconocimiento de los otros y del querer lo universal. (Cfr. Houlgate, 1995: 873)

Si el despliegue dialéctico de las formas de existencia de la libertad se detuviese aquí, la definición del "bien" dependería solamente del sujeto, lo que le hace pensar a Hegel que la moralidad debe tener, seguramente, otro fundamento. Hegel advierte entonces que el bien que sólo es "deber ser" tiene un límite y un opuesto: la realidad; en tanto que la subjetividad que sólo "debe ser buena" también es limitada y tiene un opuesto: el bien. (Cfr. FD, §141, Observación) Y es así como la eticidad se prefigura como aquel ser-allí de la libertad que puede evitar una nueva configuración arbitraria del derecho.

Diversos intérpretes de Kant consideran, sin embargo, que la crítica de Hegel es injusta. Sedgwick, Wood y Allison, entre otros, coinciden en que la preocupación de Kant no era, en principio, la de llegar al establecimiento de deberes determinados, sino simplemente mostrar que la razón es práctica por sí misma, es decir, que la razón es capaz de autodeterminarse prescindiendo del sentimiento, de toda materia e incluso de todo fin particular que pudiera fungir como su fundamento. Tales autores nos recuerdan que Kant está en la búsqueda del "principio supremo de la moral", mismo que debe gozar de necesidad absoluta. En ese sentido, no tiene caso esperar, como hace Hegel, las determinaciones que dotarían de contenido a la voluntad.

Sally Sedgwick comenta que Kant está involucrado en dos proyectos distintos: uno en donde "el contenido" de la voluntad no juega ningún papel y otro en el que figura de modo considerable. Uno es el de la "filosofía moral pura" (que acabamos de referir), donde se trata de establecer a priori la validez objetiva del principio supremo de la moral, y el otro es la "pragmática", donde se trata de demostrar que la ley moral puede aplicarse en un sistema de deberes particulares. Según esto, Hegel parece ignorar que se trata de dos proyectos y exige que haya contenidos morales desde el primero de ellos. (Cfr. Sedgwick, 1988: 77) 
Allan Wood también abona en este sentido, cuando escribe que el "principio supremo de la moralidad" no está para dictar lo que debe hacer el sujeto moral en cada caso particular, sino simplemente para sostener y justificar un sistema general de normas y deberes, y para proveer una racionalidad general que nos permita decidir en aquellos casos de conflicto e indeterminación. Es por eso que en Kant no existe una ruta para determinar deberes específicos a partir de un principio supremo. Lo que sí está claro son las ideas generales de la autonomía racional, la dignidad de todos los seres racionales como fines en sí mismos y las leyes por medio de las cuales querrían estos conducirse. Aun así, el principio supremo de la moralidad admite una formulación material, cuando nos ordena tomar al ser humano como un fin en sí mismo. La lectura de Hegel sería pues injusta. (Cfr. Wood, 2006: 343-380)

Al respecto, quizá convenga comenzar por advertir que Hegel no está menos interesado que Kant en demostrar que la voluntad libre es auto-legisladora. Hay que recordar que cuando Hegel explora el contenido de la voluntad comienza precisamente con un momento de pura indeterminación en donde la voluntad se abstrae de todo contenido particular, donde está consigo misma y sus posibilidades infinitas. La diferencia, como hemos hecho notar en diversas ocasiones, es que, de acuerdo con Hegel, cuando la voluntad libre se aborda filosóficamente, de lo que se trata es de explorar el modo en que ésta se determina inmanentemente. Según hemos anotado, este tipo de procedimiento permite demostrar que el aspecto universal y el particular de la voluntad, la forma y el contenido, llegan a superar sus expresiones meramente aisladas.

Aquí el asunto es entonces que, atendiendo al despliegue dialéctico de la voluntad libre en su existencia, la principal de las carencias que Hegel halla en la moralidad no es exactamente la falta de contenido y de deberes específicos, sino la relación de externalidad que luego se establece y se afianza como algo necesario entre la voluntad subjetiva autónoma y todo aquello que se le presenta como lo simplemente "otro": ya sea el sentimiento, el querer finito particular, la objetividad existente o la realidad... En la moralidad "lo querido no pasa de ser un fin que no ha sido llevado a cabo" y que debe, por tanto, distinguirse de su concepto "existente en sí" (Cfr. FD, § 25). Hegel nos dice también que, en la moralidad, "el fundamento esencial y primero no es la voluntad en cuanto racional y existente en y por sí, sino en cuanto voluntad del individuo según su propio arbitrio; o sea que no es el espíritu en cuanto espíritu verdadero, sino en cuanto individuo particular..." 
(FD, § 29) La moralidad se revela, así, como un ser-allí limitado y unilateral de la libertad, una configuración que no soporta al otro en su interior; es una configuración in-esencial de la libertad que debe tener en otro su fundamento.

Allison piensa, por su parte, que la diferencia entre Hegel y Kant radica en la fuente de las normas. Según esto, en la propuesta de Kant las normas provendrían de la razón práctica del agente y, en la de Hegel, de las leyes e instituciones existentes objetivamente. ¿Quiere Allison decir con esto que, según Hegel, las normas no tienen su fuente en la razón práctica? Si es el caso, pensamos que no es así. El problema es que, en el caso de Kant, si bien la fuente de las normas es la razón práctica del agente, éste tiene una dificultad sistemática para identificarse en las leyes e instituciones existentes; dicho ámbito no parece gozar nunca de racionalidad a los ojos del sujeto moral para quien el "bien" siempre es algo que está por realizarse; el problema es que las leyes e instituciones existentes siempre son algo "otro" y nunca algo otro-de-sí. En el tratamiento filosófico hegeliano de la libertad, por el contrario, como el propio Allison reconoce, un sujeto sólo llega a ser libre en la medida que otro sujeto, también libre, lo reconoce como tal; todo ser libre requiere del otro, y el sujeto autónomo requiere de las instituciones existentes objetivamente. (Cfr. Allison, 2006: 403408) En esta misma línea, Leyva comenta que

Hegel coloca a la base del derecho no a los individuos aislados ni a una totalidad que abarcaría en forma distinta a todos los individuos por igual, sino más bien a las relaciones y figuras intersubjetivas, sociales, solamente en el interior de las cuales los individuos llegan a ser tales. De acuerdo con esto, la autonomía, la libertad de los individuos, no puede ser comprendida independientemente de las relaciones intersubjetivas en las que los individuos se encuentran por principio situados. (Leyva, 2000: 124-126)

La necesidad de superar la moralidad, entonces, no es un agregado hegeliano; no se refiere tampoco principalmente a la falta de deberes determinados, ni a la proposición de otra fuente de las normas, sino a una necesidad que proviene del interior de la propia moralidad. Por un lado, en la configuración de la libertad como moralidad se tiende a percibir a los otros y a las leyes e instituciones existentes, como algo simplemente ajeno, ya que "el bien" siempre es algo querido y sabido sólo por la voluntad subjetiva, en su interior. Por el otro, si bien la libertad se configura propiamente como autonomía en el momento de la moralidad, ésta es al mismo tiempo la posibilidad del engaño, del auto-engaño, de las "buenas intenciones", de la hipocresía, de la ironía y demás, toda vez que el reconocer al otro y al derecho universal es un acto dejado al arbitrio de la voluntad subjetiva. La 
moralidad no puede ser, entonces, aquella forma de existencia de la libertad que mejor se auto-determina, esto es, la que se ve menos determinada por algún factor extraño. He aquí la necesidad de transitar a la eticidad, a esa configuración de la libertad en donde "La voluntad existente en y por sí es verdaderamente infinita, porque su objeto es ella misma, o sea que no es otro ni un límite, sino que en él ella ha retornado a sí. (FD, § 22) (...) Sólo en esta libertad está la voluntad consigo misma, porque no se relaciona con nada que no sea ella misma, con lo cual desaparece toda relación de dependencia con algo otro." (FD, § 23).

Con todo, es preciso subrayar que la configuración de la libertad como eticidad no implica anular la moralidad; simplemente se supera su carácter unilateral, porque las nuevas determinaciones en las que la idea de la libertad se determina provienen de su interior; son su desdoblamiento, y no un contenido añadido por el filósofo que la estudia. Hegel puede afirmar por eso que lo ético es precisamente una "disposición subjetiva, pero [una disposición] que pertenece al derecho existente en sí.” (FD, §141, Observación)

Y es necesario reiterar, por último, que la eticidad es una configuración a la cual se accede de modo necesario, cuando se sigue el despliegue dialéctico de la propia voluntad en su existencia y se advierte que la moralidad entra en contradicción. Primero se demuestra que la libertad como "derecho abstracto" tiene en otro su fundamento: la moralidad. Y ahora se descubre que la moralidad requiere también de otro fundamento: la eticidad.

...el derecho y la autoconciencia moral muestran en sí mismos que desembocan en ella como en su resultado. (...) Si la moralidad es pues la forma de la voluntad según el lado de la subjetividad, la eticidad no es ya meramente la forma subjetiva y la autodeterminación de la voluntad, sino el tener como contenido su propio concepto, es decir, la libertad. Lo jurídico y lo moral no pueden existir [entonces] por sí y deben tener lo ético como sostén y fundamento. (FD, §141, Agregado)

No proseguiremos con el desarrollo que hace Hegel de la última de las configuraciones de la libertad en su existencia. Al revisar las dos primeras secciones de la Filosofía del Derecho ya hemos delineado su modo peculiar de conceptualizar, que es lo que aquí se pretendía destacar. Más allá de las opiniones externas que Hegel pueda tener "en torno" al derecho, lo que interesaba observar era el modo propuesto por Hegel para seguir el despliegue de la 
propia voluntad en su existencia, y creemos que dicho cometido se logra con lo expuesto hasta este punto. 


\section{CONCLUSIONES}

En el curso del presente trabajo hemos intentado destacar la importancia de leer la Filosofía del Derecho de Hegel a la luz de su Ciencia de la Lógica. En el Prefacio a la Filosofía del Derecho se nos advierte que la obra está regida por el mismo espíritu lógico que sostiene a todo el sistema hegeliano. Sin embargo, por estar destinada al tratamiento filosófico de un objeto concreto (la Idea del Derecho), al autor le parece inadecuado referirse nuevamente al procedimiento y al método. Asimismo, considera inapropiado demostrar en cada caso la concatenación lógica de los conceptos involucrados en la ciencia filosófica del derecho. Pero una cosa es clara: si se quiere comprender correctamente el sentido y la argumentación de la Filosofía del Derecho, es necesario tener en cuenta el modo en que éste se apega a la Ciencia de la Lógica.

Y es que, según lo expuesto en el primer apartado, la Ciencia de la Lógica contiene unas exigencias que, de acuerdo con Hegel, toda ciencia filosófica debiera atender; señala pues el modo en que la filosofía debiera tratar su objeto. Al respecto, toda ciencia filosófica tendría que comenzar con la suspensión de las reflexiones preliminares a la propia investigación; tendría que comenzar por lo más indeterminado, y no debiera avanzar sino por donde la lleva el objeto que se niega y se contradice internamente.

En un segundo apartado constatamos que la crítica de las ciencias empíricas del derecho y de las ciencias formales del derecho, crítica expuesta en el ensayo sobre el Derecho Natural, representa ya una primera intervención hegeliana por ocuparse de la idea del Derecho bajo una lógica distinta, la lógica más apropiada para una ciencia filosófica, evitando la unilateralidad de las posturas precedentes.

Por lo que vimos en el tercer y cuarto apartado, este es el procedimiento que sigue Hegel en la Filosofía del Derecho, cuando se ocupa del contenido de la voluntad, y cuando se ocupa de las configuraciones de la voluntad en su existencia. Bajo este procedimiento, lo que tenemos es que el contenido de la voluntad se despliega en tres momentos: la pura 
indeterminación, la particularización y la autodeterminación concreta. Bajo este procedimiento tenemos también que la voluntad se realiza necesariamente como derecho abstracto, como moralidad y como eticidad.

Al ocuparse filosóficamente de la libertad, queda claro que Hegel no opina de antemano que la libertad individual sea una configuración inapropiada. Tampoco afirma por anticipado que las configuraciones más concretas de la libertad (la familia, la sociedad civil y el Estado), deban imponerse como las únicas realmente válidas. Por el contrario, al explorar el contenido de la voluntad y al atenerse al despliegue de las configuraciones de la voluntad en su realización, se demuestra que cada momento del concepto goza de derecho propio y que no puede prescindirse de ninguno de ellos, aunque tampoco debe afirmárselos unilateralmente. En todo caso, es posible apreciar que cada momento del concepto entra en contradicción consigo mismo y exige realizarse de otro modo. Visto lo anterior, no cabe pues afirmar sin más que, en Hegel, las instituciones de la vida ética se antepondrían a la libertad individual. Lo que su tratamiento filosófico de la libertad nos indica precisamente es que, lejos de opinar o decidir cuál de las configuraciones de la libertad es la más adecuada, el filósofo debiera atenerse al despliegue del objeto mismo.

Adicionalmente, cuando la Filosofía del Derecho se revisa bajo la perspectiva de la Lógica, se demuestra que la concepción de la libertad en Hegel no sólo no es reaccionaria, sino que incluso nos permite realizar un ejercicio de crítica frente a ciertos planteamientos modernos y contemporáneos. En diversos planteamientos de la filosofía política moderna y contemporánea sí se aprecia la tendencia a optar de antemano por alguna de las configuraciones de la libertad, la libertad subjetiva; de modo que las investigaciones filosóficas ya sólo consisten en afianzar un punto de vista del cual ya se está convencido previamente. Se afirma también que es un error considerar que la libertad se realiza en instituciones como la familia, la sociedad civil o el Estado, porque se incurre en antropomorfismo cuando se piensa en dichas instituciones como entidades "libres". En este sentido, lo que el planteamiento hegeliano viene a decirnos es que no tenemos por qué optar por una configuración u otra, sino que debe atenderse a la propia voluntad en su despliegue. El objeto de la filosofía demuestra ser contradictorio en sí mismo, estar marcado por la negación. No es que la voluntad libre sea subjetiva u objetiva, o bien subjetiva y objetiva a la vez, como aspectos separados que ya se excluyen, ya se mezclan. Lo que el tratamiento filosófico de la libertad en Hegel nos demuestra es precisamente que la voluntad se realiza 
como sí en lo otro-de-sí. Dicho en otros términos, la libertad subjetiva se realiza como tal en lo objetivo (que es lo otro-de-sí); en tanto que las instituciones de la vida ética realizan la libertad en sí en lo otro-de sí que es la libertad subjetiva. No existe pues una relación de extrañeza entre ambas configuraciones. Caso contrario, cuando el filósofo afirma arbitrariamente y por anticipado que una u otra configuración es la mejor, se corre el riesgo de justificar, entonces sí, experiencias como la de un Estado omnipresente para el cual el individuo es algo secundario o, viceversa, la superposición de la libertad individual. En cualquiera de estos casos, entonces sí que se obstaculiza la realización de la libertad en sus otras configuraciones, según puede advertirse en la experiencia reciente de nuestro propio país. 


\section{BIBLIOGRAFÍA}

- ALLISON, Henrry E. (2006). "Kant on freedom of the will". En: Paul Guyer, The Cambridge Companion to Kant and Modern Philosophy. Cambridge University Press.

- AMENGUAL Coll, Gabriel, Ed. (2001). La moral como derecho. Estudio sobre la moralidad en la Filosofía del Derecho de Hegel. Trotta, Madrid.

- - (1961). "The Problem of War in Hegel's Thought". En: Journal of the History of Ideas, Vol. 22, No. 4 (Oct. - Dec., 1961), pp. 463-474. University of Pennsylvania Press.

- BEISER, Frederick (2005). Hegel. Routledge, Nueva York.

- ------ (1993). The Cambridge Companion to Hegel. Cambridge University Press, Cambridge.

- BERLIN, Isaiah (2004). La traición de la libertad: seis enemigos de la libertad humana. Fondo de Cultura Económica, México.

-

- BOBBIO, Norberto, (1989). "Hegel y el iusnaturalismo"; en: Gabriel Amengual (Ed.) Estudios sobre la "Filosofía del Derecho" de Hegel. Centro de Estudios Constitucionales, Madrid.

- CASSIRER, Ernst (1997). El mito del Estado. Fondo de Cultura Económica; México.

- COHEN, Jean L. y Andrew Arato (2000). Sociedad civil y teoría política. fondo de Cultura Económica, México.

- CUARTANGO, Román (1999). Una nada que puede ser todo. Reflexividad en la Ciencia de la Lógica de Hegel. Editorial Límite; Santander.

- DRI, Rubén (1999). La odisea de la conciencia moderna: hermenéutica del capítulo VI de la "Fenomenología del espíritu". Biblos, Buenos Aires.

- DUQUE, Félix (1999). La Restauración. La Escuela hegeliana y sus adversarios. Akal, Madrid.

- GADAMER, Hans-Georg [1980] (2007). La dialéctica de Hegel. Cinco ensayos hermenéuticos. Cátedra, Madrid.

- GIUSTI, Miguel (Coord.) (2003). El retorno del espíritu. Pontificia Universidad Católica del Perú, Perú.

- GUYER, Paul (1993). "Thought and Being. The Hegel's critic of philosophy of Kant". En: Frederick Beiser (Ed.) The Cambridge Companion to Hegel. Cambridge University Press, Cambridge.

- HABERMAS, Jürgen (1990). Pensamiento postmetafísico. Altea, Taurus, Alfaguara; México.

- HEGEL, G. W. F. (1968). Ciencia de la Lógica. Ediciones Solar, Buenos Aires. Dos tomos.

Madrid.

-

-

- $\quad$---------- (1966) Fenomenología del Espíritu. FCE, México.

- ------------ (2000) Fe y saber. O la filosofía de la reflexión de la subjetividad en la totalidad de sus formas como filosofía de Kant, Jacobi y Fichte. Biblioteca Nueva; Madrid.

- ----o (1988), Principios de la Filosofía del Derecho. O Derecho Natural y Ciencia política. EDHASA, Barcelona. 
(1979). Sobre las maneras de tratar científicamente el derecho natural. Su lugar en la filosofía práctica y su relación constitutiva con la ciencia positiva del derecho. Aguilar, Madrid.

- HOBHOUSE, L. T. [1918] (1999). The metaphysical theory of the state. A criticism. Batoche Books. Ontario, Canada.

- HOBBES, Thomas, (2001). Leviatán. O la materia, forma y poder de una república eclesiástica y civil. Fondo de Cultura Económica. México.

- HOULGATE, Stephen (1995). "The unity of theoretical and practical spirit in Hegel's concept of freedom". En: The Review of Methaphysics, v. 48, June 1995. The Philosophy Education Society. Pp. 859-881.

- $\quad$---- (2006). The opening of Hegel's Logic. From Being to Infinity. Purdue University Press; West Lafayette, Indiana.

- HYPPOLITE, Jean (1996). Lógica y existencia. Herder, Barcelona.

- KAIN, Philip (2005). Hegel and the Other. A Study of the Phenomenology of Spirit. State University of New York Press, Albany.

- KANT, Immanuel (1961) Crítica del juicio. Losada, Buenos Aires.

- - --------- (1961). Crítica de la razón práctica. Espasa-Calpe, México.

-

-

- ----------- (1981). Fundamentación de la metafísica de las costumbres. Espasa-Calpe, Madrid.

- $\quad$---------- (2005). La Metafísica de las costumbres. Tecnos, Madrid.

-

- ------------- (1980). Prolegómenos a toda metafísica del porvenir. Aguilar, Buenos Aires.

- LEYVA, Gustavo (2000). "La superación de la ética en la Rechtsphilosophie de Hegel". En: PIÑÓN, Francisco y Joel Flores (coords.), Ética y política: entre tradición y modernidad. UAMI/Miguel Ángel Porrúa/Centro de Estudios Antonio Gramsci/Plaza y Valdez.

- LÓPEZ Hernández, José (2000). "Actualidad y vigencia de la Filosofía del Derecho de Hegel”. En: Revista de Estudios Políticos, número 110, octubre-diciembre 2000, págs. 175-195. Centro de Estudios Constitucionales, Madrid.

- MARRADES, Julián (2001). El trabajo del Espíritu. Hegel y la modernidad. A. Machado libros, Madrid.

- - ----- (2006). "Estado y guerra en Hegel”; en: SÁNCHEZ Durá, Nicolás (ed.) La Guerra. Pre-Textos, Valencia. Pp. 11-34.

- NEUHOUSER, Frederick (2000). Foundations Hegel's social theory: actualizing freedom. Harvard University, Cambridge.

- NG, Karen (2009). "Hegel's Logic of Actuality". En: The Review of Metaphysics; Sep. 2009, № 63. ProQuest Humanities Module. Pp. 139-172.

- PATTEN, Alan (2002). Hegel's idea of freedom. Oxford University Press.

- PAWLIK, Michael (2005). La realidad de la libertad: dos estudios sobe la Filosofía del Derecho de Hegel. Universidad Externado de Colombia, Bogotá.

- PEPERZAK, Adriaan (1987). Philosophy and politics: a commentary on the preface to Hegel's Philosophy of Right. M. Nijhoff; Dordrecht, Boston.

- - - (1989). "Los fundamentos de la ética según Hegel". En: Gabriel Amengual (Ed.) Estudios sobre la "Filosofía del Derecho" de Hegel. Centro de Estudios Constitucionales, Madrid. 
- PÉREZ Soto, Carlos (2008). Desde Hegel. Para una crítica radical de las ciencias sociales. Ítaca, México.

- PINKARD, Terry (1986). "Freedom and Social Categories in Hegel's Ethics". En: Philosphy and Phenomenological Research, Vol. 47, $\mathrm{N}^{\circ} 2$ (Dic. 1986), pp. 209-232. International Phenomenological Society.

- - ----- (1979). "The Logic of Hegel's Logic”, en: Journal of the History of Philosophy, volume 17, number 4, October 1979; pp. 417-435. The Johns Hopkins University Press.

- PIPPIN, Robert (1981). "Hegel's Political Argument and the Problem of Verwirklichung". En: Political Theory, Vol. 9, No. 4 (Nov., 1981), pp. 509-532. Sage Publications Inc.

Press, Cambridge.

- - (2000). "Hegel's practical philosophy: the realization of freedom", en: AMERIKS, Karl. The Cambridge Companion to German Idealism. Cambridge University Press, Cambridge.

- ROSENFIELD, Denis (1989). Política y libertad. La estructura lógica de la Filosofía del Derecho de Hegel. Fondo de Cultura Económica, México.

- SEDGWICK, Sally (1996). "Hegel's Critique of Kant's Empiricism and the Categorical Imperative.". En: Zeitschrift für philosophische Forschung, Bd. 50, H. 4 (Oct.-Dec. 1996), pp. 563-584. Vittorio Klostermann $\mathrm{GmbH}$.

- - ------- (1988). "On the Relation of Pure Reason to Content: A Reply to Hegel's Critique of Formalism in Kant's Ethics." En: Philosophy and Phenomenological Research, vol. 49, $\mathrm{n}^{\circ} 1$ (sep. 1988); pp. 59-80. International Phenomenological Society

- SERRANO Gómez, Enrique (2004). La insociable sociabilidad. El lugar y la función del derecho y la política en la filosofía de Kant. Anthropos, España.

- SMITH, Steven (2002). Hegel y el liberalismo político. Ediciones Coyoacán, México.

American Political Science Review, Vol. 77, No. 3 (Sep., 1983), pp. 624-632. American Political Science Association.

- STEINBERGER, Peter (1988). Logic and politic: Hegel's philosophy of right. Yale University Press, New Haven

- TAYLOR, Charles (1975). Hegel. Cambridge University Press, New York.

- VALLS Plana, Ramón (1994). Del yo al nosotros. Lectura de la Fenomenología de Hegel. PPU, Barcelona. Tercera edición.

-

- WILLIAMS, Robert (1997). Hegel's Ethics of Recognition. University of California Press.

- WOOD, Allen (1993). "Hegel's ethics". En: Frederick Beiser, The Cambridge Companion to Hegel. Cambridge University Press, Cambridge.

- --------- (2006). "The Supreme Principle of Morality". En: Paul Guyer, The Cambridge Companion to Kant and Modern Philosophy. Cambridge University Press.

Ciudad de México, febrero del 2012. 